Andrews University

Digital Commons @ Andrews University

1989

\title{
A Proposed Strategy for Evangelizing the Hindus of the Republic of Trinidad and Tobago
}

Wynall F. Kerr

Andrews University

Follow this and additional works at: https://digitalcommons.andrews.edu/dmin

Part of the Practical Theology Commons

\section{Recommended Citation}

Kerr, Wynall F., "A Proposed Strategy for Evangelizing the Hindus of the Republic of Trinidad and Tobago" (1989). Professional Dissertations DMin. 684.

https://dx.doi.org/10.32597/dmin/684

https://digitalcommons.andrews.edu/dmin/684

This Project Report is brought to you for free and open access by the Graduate Research at Digital Commons @ Andrews University. It has been accepted for inclusion in Professional Dissertations DMin by an authorized administrator of Digital Commons @ Andrews University. For more information, please contact repository@andrews.edu. 


\section{ABSTRACT}

A PROPOSED STRATEGY FOR EVANGELIZING THE HINDUS

OF THE REPUBLIC OF TRINIDAD AND TOBAGO

\section{by}

Wynall F. Kerr

Faculty Adviser: Walter B. T. Douglas, Ph.D. 


\title{
ABSTRACT OF GRADUATE RESEARCH
}

A Project Report

\author{
Andrews University \\ Seventh-day Adventist Theological Seminary
}

Title: A PROPOSED STRATEGY FOR EVANGELIZING THE HINDUS OF THE REPUBLIC OF TRINIDAD AND TOBAGO

Name of researcher: Wynall F. Kerr

Name and degree of faculty adviser: Walter B. T. Douglas, $\mathrm{Ph}$. D.

Date completed: December 1989

\section{Problem}

Substantial investments been made in the evangelization of Hindus in Trinidad, but have resulted in little success. The Seventh-day Adventist Church in Trinidad has not yet developed a well-defined approach to assist pastors and laity in evangelizing Hindus. The purpose of this study was to develop a biblically informed strategy 
of evangelism that can be used in designing appropriate evangelistic methods.

\section{Method}

The New Testament and other selected literature have suggested a strategy and methods of evangelism that were used for evangelizing particular peoples or groups of people, and these might inform the mission of the seventhday Adventist Church in Trinidad to Hindus there.

This project report has four sections: (1) a study of biblical and theological understanding of evangelism (2) a survey of Hinduism in Trinidad, (3) a survey of selected literature concerning principles for evangelizing Hindus, and (4) the development of an intentional, workable strategy and programs for evangelizing the Hindus of Trinidad.

\section{Conclusion}

The pastors and church members who attempt to evangelize Hindus of Trinidad need a definitive strategy so that evangelistic methods used intentionally.

A study of Matt 28:18-20 reveals all disciples of Jesus are to evangelize everyone everywhere. The response to this gospel commission recorded in the Acts of the Apostles reveals that the apostles: (1) moved from the less difficult to the more difficult situations; surrendered to the ministry of the Holy spirit;

(3) went 
to wherever the people were; (4) appropriately contextualized their evangelistic methods; and

employed the people-movement approach to those with little or no exposure to the gospel. They made no attempt to customize Christianity.

Seventh-day Adventists in Trinidad, to effectively evangelize the Hindus there, need to: (1) develop a positive attitude towards cultures, and Hinduism; use strategy for evangelizing the Hindus that provides the needed parameters for innovation and experimenting with a variety of methods; (3) encourage Seventh-day Adventist of East Indian descent to evangelize Hindus; and (4) observe the principles of indigenization and contextualization. 


\author{
Andrews University \\ Seventh-day Adventist Theological Seminary
}

A PROPOSED STRATEGY FOR EVANGELIZING THE HINDUS

OF THE REPUBLIC OF TRINIDAD AND TOBAGO

\author{
A Project Report \\ Presented in Partial Fulfillment \\ of the Requirements for the Degree \\ Doctor of Ministry
}

by

Wynall F. Kerr

December 1989 

C Copyright 1989, Wynall F. Kerr

All Rights Reserved 
A PROPOSED STRATEGY FOR EVANGELIZING THE HINDUS

OF THE REPUBLIC OF TRINIDAD AND TOBAGO

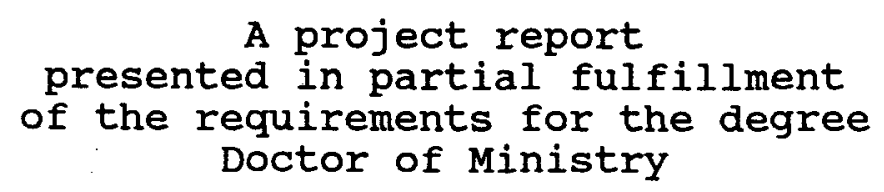

by

Wynall F. Kerr

APPROVAL BY THE COMMITTEE:
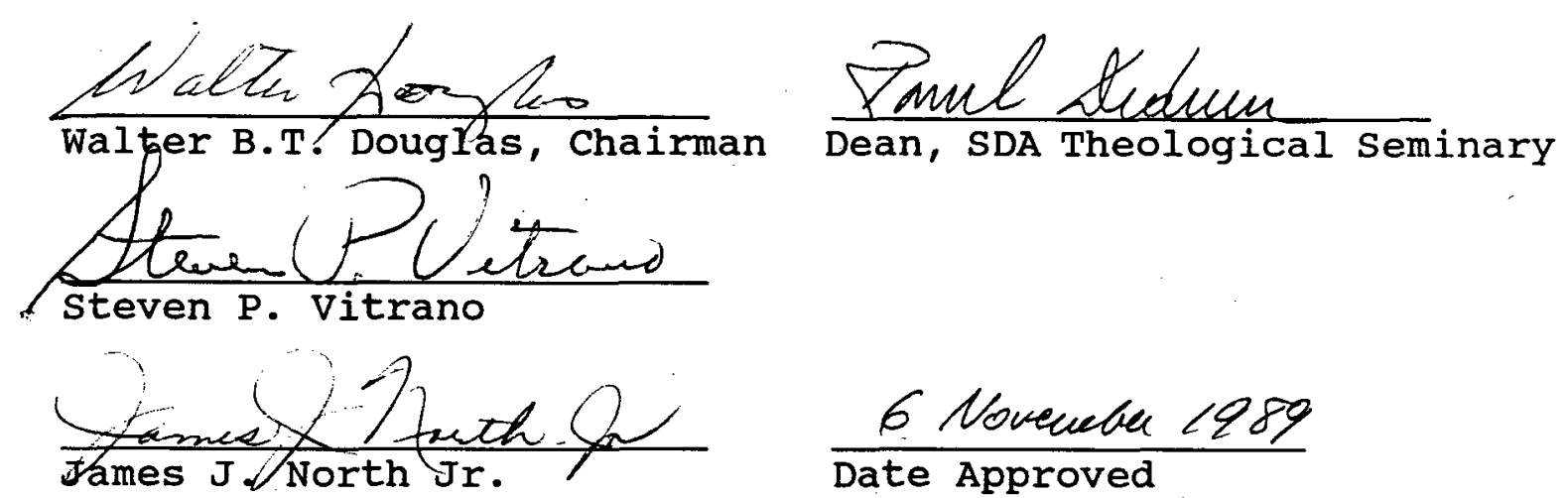

$\frac{6 \text { Noveuda } 1989}{\text { Date Approved }}$ 

TABLE OF CONTENTS

ACKNOWLEDGEMENTS ......................... ix

Chapter

I. INTRODUCTION...................... 1

Purpose of the Project.................... I

Justifications for the Project............ 1

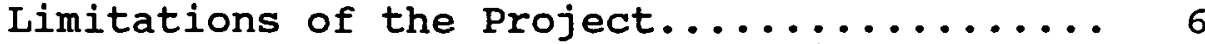

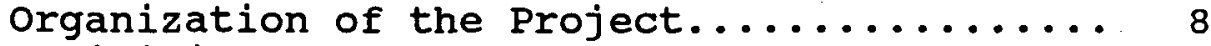

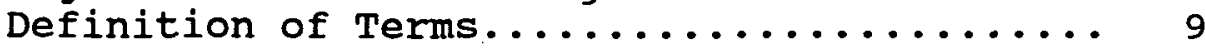

PART I

A BASIC THEOLOGY OF EVANGELISM AMONG THE HINDUS IN THE REPUBLIC OF TRINIDAD AND TOBAGO

II. DEFINITION AND THEOLOGY OF EVANGELISM........ 13

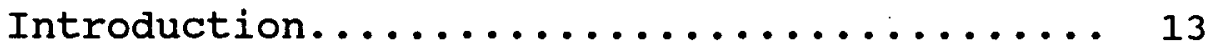

Towards a Theological and Biblical

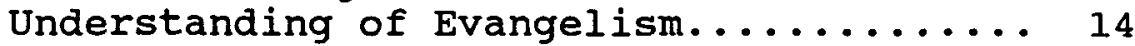

Jesus' Evangelistic Commission............ 19

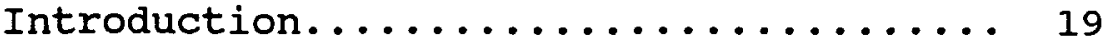

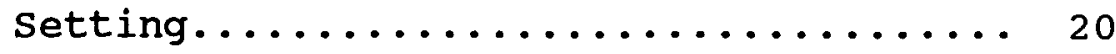

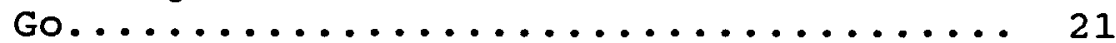

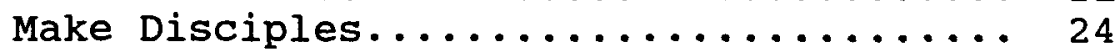

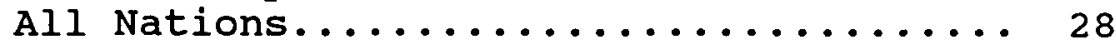

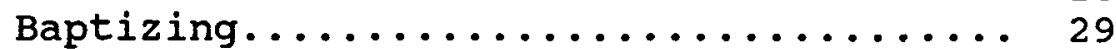

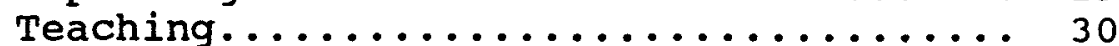

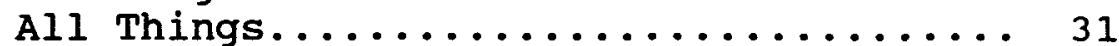

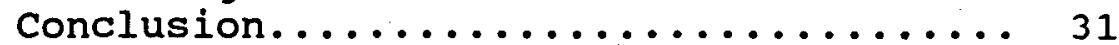

An Evangelistic strategy from the

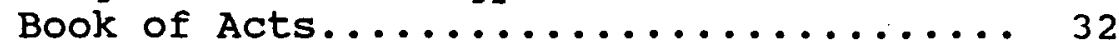

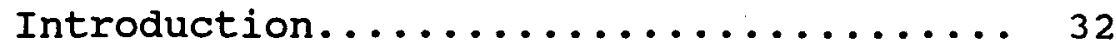

The Book Acts of the Apostles.......... 33

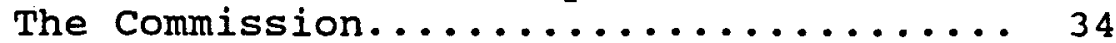

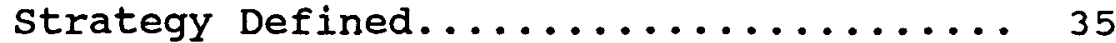

Ministry in Jerusalem (Acts 2-7) ....... 36

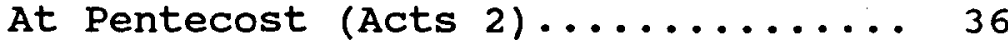

Solomon's Porch (Acts 3,4) ........ 38

Stephen (Acts $6: 8-7: 60) \ldots \ldots \ldots \ldots 39$ 
Conclusions................. 40

Ministry in Judea and Samaria........ 40

Strategic Reorganization

(Acts $6: 1-7$ )............ 40

Ministry in Samaria (Acts $8: 1-13$ ) ... 42

Ministry in Judea (Acts $9: 32-11: 30$ ). 44

Ministry to the Uttermost Parts of the

Earth (Acts $13-20) \ldots \ldots \ldots \ldots \ldots, 46$

By the Riverside (Acts $16: 14,15) \ldots 47$

The Philippian Jailer

(Acts $16: 16-34) \ldots \ldots \ldots \ldots \ldots \ldots 48$

Athens (Acts $17: 15-34 \ldots \ldots \ldots \ldots \ldots, 48$

Corinth (Acts 18:1-11).......... 50

Conclusion................... 51

Household $\backslash$ Family Evangelism............ 53

Selected old Testament Parallels.......... 56

summary.................. 57

The Related Implications of Matt $10: 34-37 \ldots 58$

All Things to All Men (1 Cor 9:19-23)...... 60

Conclusion....................... 64

III. TRINIDAD AND HINDUISM.............. 67

Introduction.................. 67

Historical Background of Hinduism

in Trinidad..................... 70

Trinidad in Historical Perspective.... 70

The East Indians............... 72

Socio-Cultural Context.......... 75

Kinship and Family........... 75

culture................. 78

Education............... 81

East Indians and Their Neighbors.... 82

Hindu sects in Trinidad.............. 84

Sanatan Dharma................. 85

Arya Samaj...................... 86

Kabir Panth...................... 87

Seunerinis (Seunarianiers)

or Siva Naryanis............. 87

Prominent Features of Hinduism............. 88

Major Hindu Scriptures.............. 88

Primary Hindu Scriptures............ 88

The vedas................. 88

Secondary Hindu Scriptures.......... 89

The Upanishads................ 90

The Two Epics................ 91

The Ramayana.............. 92

The Mahabharata............ 92

Bhagavad Gita............... 93

Cannonization of Hindu Scriptures, , , ... 93

The Bhagavad Gita.............. 95

Hindu Dieties.................... 96 


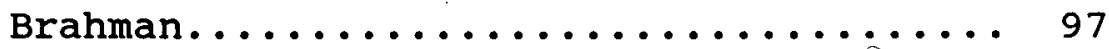

The $\operatorname{Triad} \ldots \ldots \ldots \ldots \ldots \ldots \ldots \ldots \ldots \ldots$

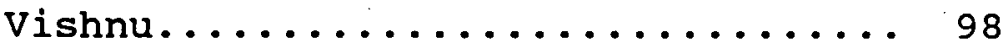

Brahma........................ 99

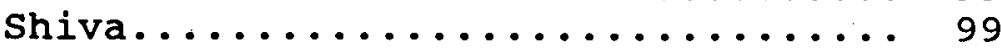

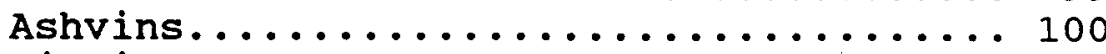

Dieties of the Lower order............ 100

"Religious" Beliefs and Practices.......... 101

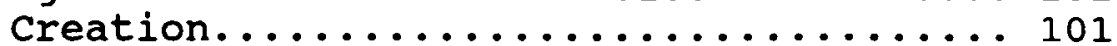

The Doctrine of Man............... 103

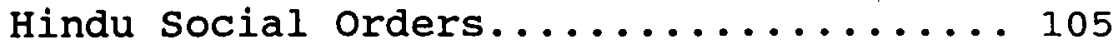

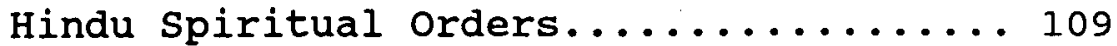

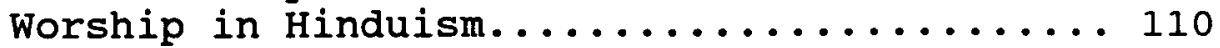

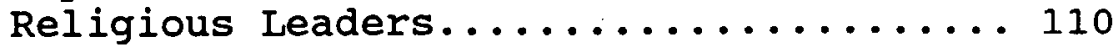

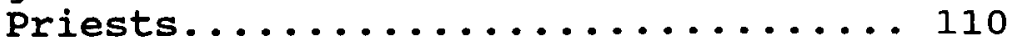

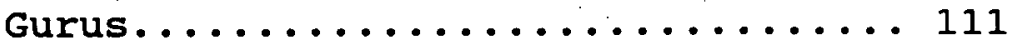

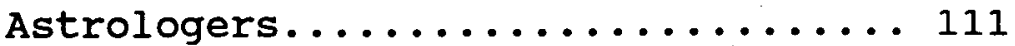

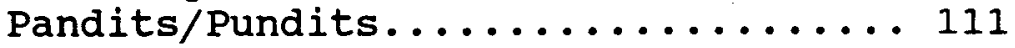

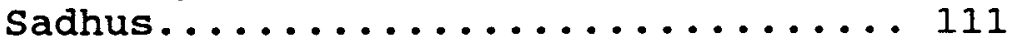

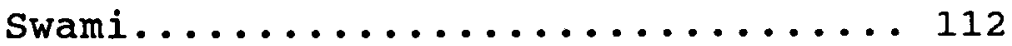

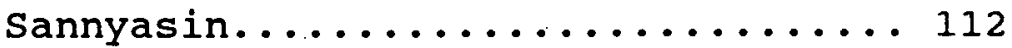

Yogi....................... 112

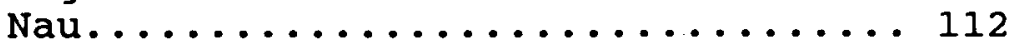

Worship Services and Ceremonies........ 112

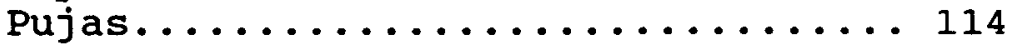

Celebration of Samskarus......... 117

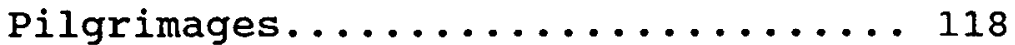

Festivals................... 119

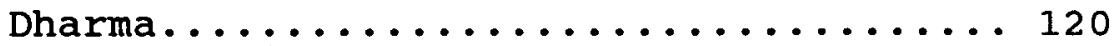

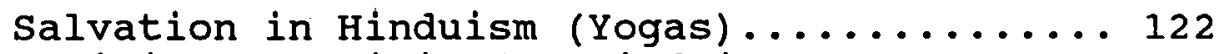

Pecularities of Trinidad's Hinduism as

Compared with India's Hinduism........... 124

Differences and Similarities between Hinduism

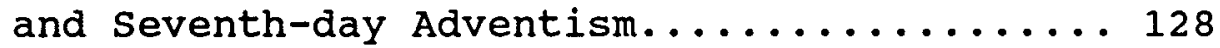

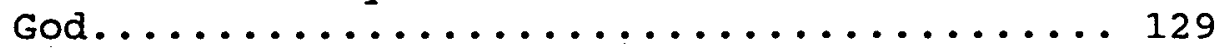

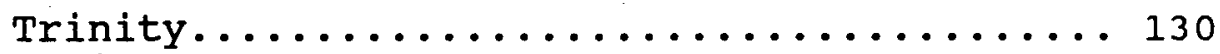

Scripture....................... 130

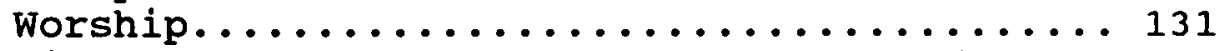

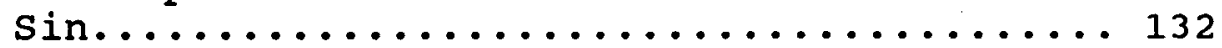

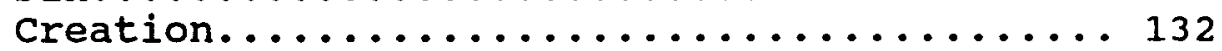

Humanity....................... 133

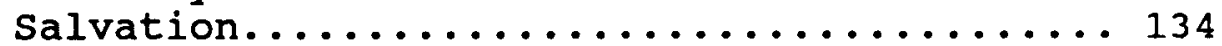

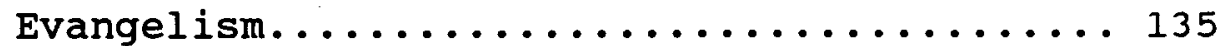

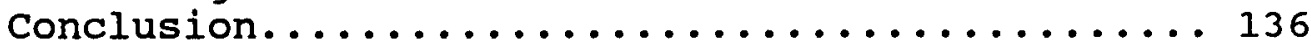

IV. REVIEW OF SELECTED LITERATURE.............. 139

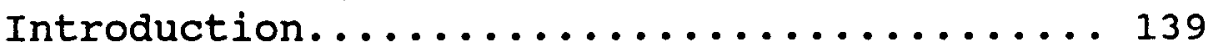

Hindu Socio-Cultural Patterns............ 140

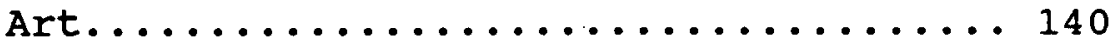

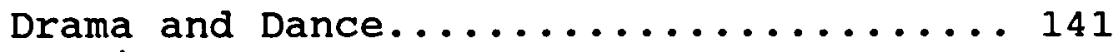

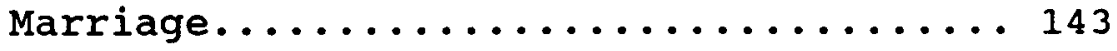




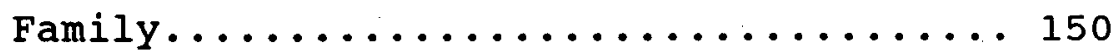

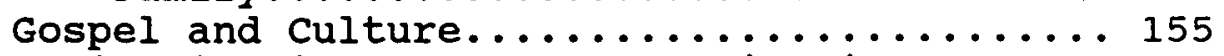

Indigenization and contextualization....... 160

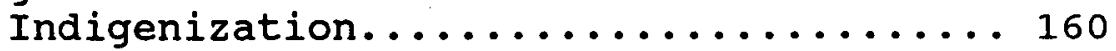

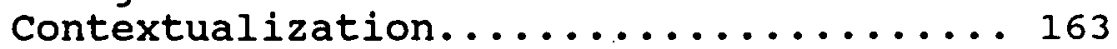

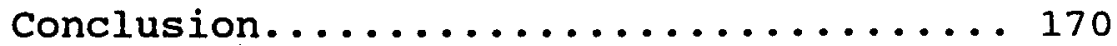

Christian/Non-Christian Dialogue......... 171

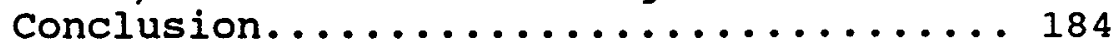

Evangelism among Hindus.............. 186

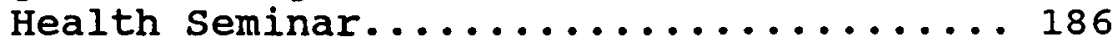

Public Evangelistic Crusade.......... 189

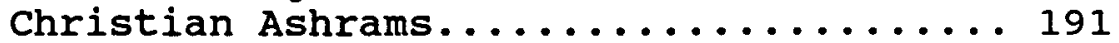

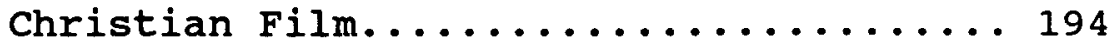

Working through Head of Family........ 195

Contextualized Gospel Meeting.......... 195

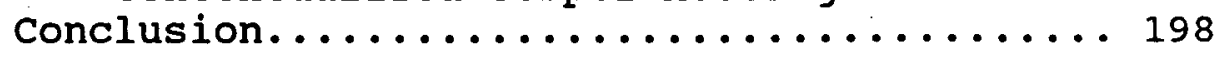

\section{PART II}

STRATEGY OF EVANGELISM AMONG THE HINDUS

IN THE REPUBLIC OF TRINIDAD AND TOBAGO

V. RECOMMENDED STRATEGY. .................. 201

Introduction.....................201

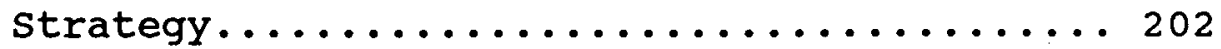

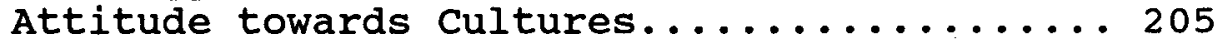

Attitude towards Hindus............... 212

People Movement Approach............... 214

Challenges of the Hindu Family........... 217

The Hindu Family and Dharma.......... 219

The Hindu Family and Marriage of

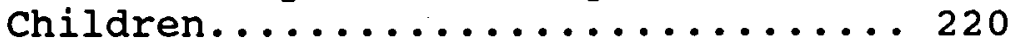

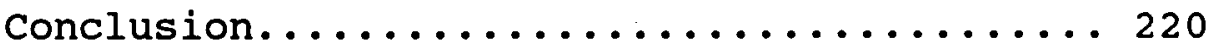

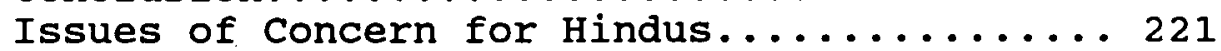

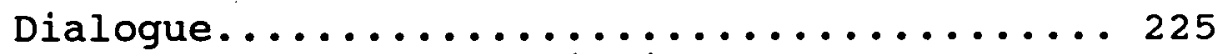

Some Suggested Evangelistic Methods........ 226

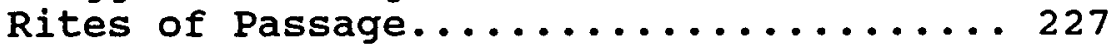

The Birth of a child............ 227

Arrival of Puberty............. 229

The Completion of College or

University Education. ............ 230

The Marriage Ceremony........... 230

Retirement/sixty-fifth or

Seventieth Birthday.......... 234

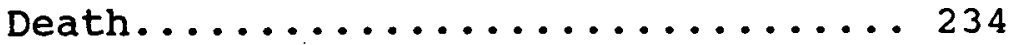

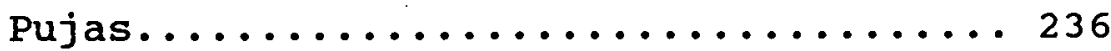

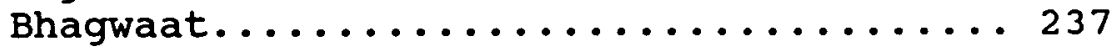

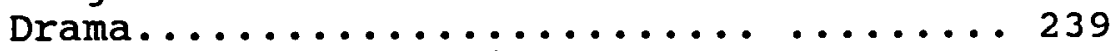

Festivals and Religious Days.......... 240

Ashrams........................ 241

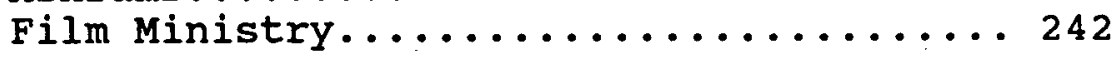

vi 
Radio Ministry................. 242

Ministry to women................ 243

Literature................... 243

Contextualization................ 244

Architecture.................. 244

Liturgy................... 245

Personnel.................. 246

The Household Church.,.......... 247

Family-Concern Ministries............ 247

Health-Concern Ministries............. 248

Community-Concern Ministries............ 249

Task Forces.................... 249

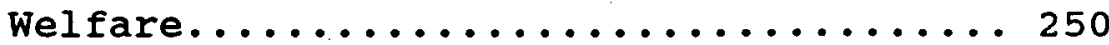

Child-Care Facilities............. 250

Purchasing co-operatives..............251

Senior-Citizens Service............251

Funeral Attendance.............. 252

Procedure for Implementation............. 252

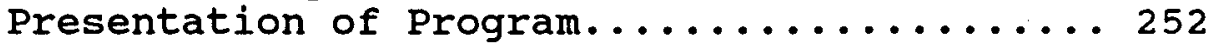

Selection of Evangelists............. 253

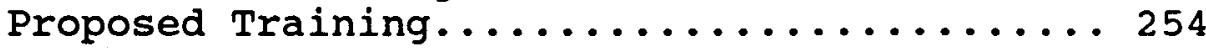

Suggested Week-End Schedule............ 255

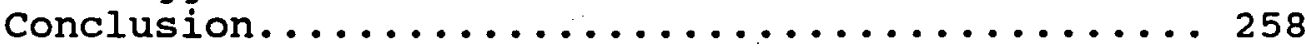

VI. SUMMARY AND CONCLUSIONS.............. 260

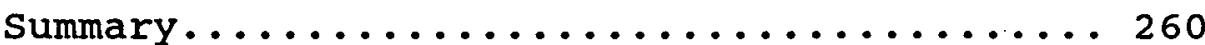

Conclusions..................... 262

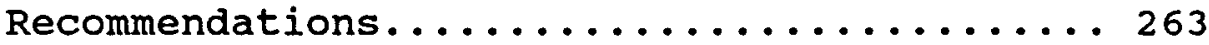

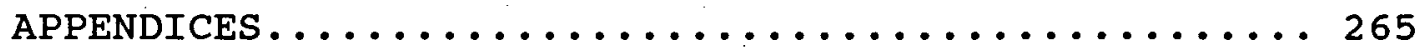

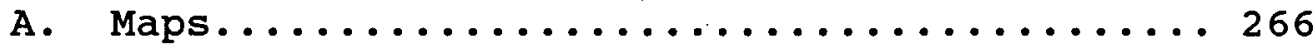

Map of India................ 267

Maps of the Republic of Trinidad and

Tobago..................... 269

B. Statistics of Population of Republic of

Trinidad and Tobago at National

Census $1961-1980 \ldots \ldots \ldots \ldots \ldots \ldots \ldots \ldots 272$

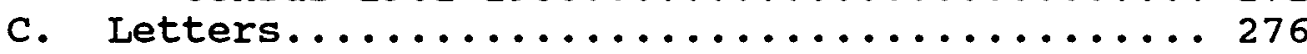

Letter and Accompanying Data from South Caribbean Conference of Seventh-day Adventist.................. 277

Letter from the office of the Prime Minister of the Republic of Trinidad and Tobago............. 280

Letter from the Sanatan Dharma Maha-Sabha of Trinidad and Tobago Incorporated................ 282 
D. Hindu Deities..................... 284

E. Selected Christian Hindi Bhajans

with English Translations........... 291

F. Test for Training Workshop.............. 305

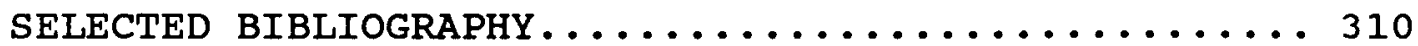

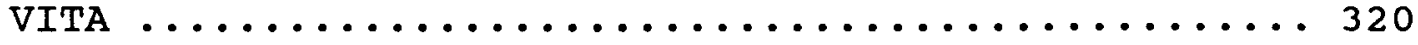




\section{ACKNOWLEDGEMENTS}

This project is the result of the accumulated effort of several person with whom interaction took place here at Andrews University.

Inspite of that however, praise and thanks must be ascribed to God apart from whom this project would never have been a reality.

It is appropriate here to identify a few persons to whom special thanks and deep appreciation should be expressed for their invaluable assistance.

To Dr. Walter B. T. Douglas, who was not only willing to serve as advisory committee chairman, but unrestrainingly offered relevant suggestions and raised pertinent questions that have significantly influenced the outcome of this project.

To Dr steven P. Vitrano whose insightful

suggestions and concern. Also to Dr James J. North Jr. whose constructive criticism and challenging questions greatly assisted in refining and shaping the final draft of this project.

Special mention must also be made of my wife Victoria who inspite of her demanding academic schedules 
was of constant invaluable help, support and encouragement throughout the development of this project. Also to my two sons Lutron and Nikå for their patience and understanding. 
CHAPTER 1

INTRODUCTION

\section{Purpose of the Project}

The purpose of the project was:

1. To examine the historical background of the East Indians in Trinidad.

2. To study the socio-cultural and religious beliefs and practices of the Hindus in Trinidad.

3. To establish a theological base for a diversified approach for evangelism that will inform a strategy of evangelism appropriate for reaching the Hindus in Trinidad.

\section{Justification for the Project}

The primary existential purpose and mission of the Seventh-day Adventist Church is to proclaim the everlast-ing gospel to all people throughout the world.' This is for the sole purpose of preparing a people, ready for the second advent of Jesus. Such an awesome

${ }^{1}$ Seventh-day Adventist Yearbook 1987 (Hagerston, Maryland: Review and Herald Publishing Association, 1987), 9. 
responsibility has challenged the church to appropriately engage all peoples with the gospel of the kingdom of God. In response to this task, the Seventh-day Adventist Church has a mission presence in 186 of the 215 countries and areas that are recognized by the United Nations.' Consequently, the Church has a total world membership of $5,203,647 . .^{2}$ Despite that, many people groups have not had an experiencially productive, formal encounter with the gospel. 3 In India, for example,

Christianity has not become a significant religious force among the peoples of India. Rather, Christianity continues to be little more than a minority religion--only 3 percent of the nation's massive population is Christian. Nearly three quarters of a billion people do not to know Jesus Christ as their Lord and Savior. ${ }^{4}$

The predominant religion of India is Hinduism.

Its adherents total about 500 million. This is 83 percent of the national population and 90 percent of all Hindus in the world. Other countries where Hinduism has been

'Annual Statistical Report (Washington, D.C.: General Conference of Seventh-day Adventist, office of Archives and Statistics, 1987), 37 .

${ }^{2}$ Seventh-day Adventist Yearbook (1988), 4 .

${ }^{3}$ Edward R. Dayton and David A. Fraser, Planning Strategies for World Evangelization (Grand Rapids, Michigan: William B. Eerdman Publishing Company, 1980), 4-5.

"Vijayan Charles, "India," Adventist Review, July $9,1987,8,9$. 
persistent are: Bangladesh, Sri Lanka, Kenya, South Africa, Trinidad and Tobago, and Guyana.'

Though the Seventh-day Adventist Church has for a long time established missionary work in these countries, ${ }^{2}$ accessions from this great religion has met with discouragingly little numerical success. For example, the Southern Asia Division, of which India forms the major part, has a population of $702,679,692$. However, the recorded Seventh-day Adventist membership is only $148,177.3$ A similar situation exists in Trinidad and Tobago.

The population of Trinidad and Tobago is 1,055,763. People of East Indian descent constitute 41 percent of the national population. These people live predominantly in the areas of the Caroni basin, the Oropouche lagoon, and in st. George and st. Patrick counties. Hindus account for 61.3 percent of the East Indian population--25 percent of the national population. ${ }^{4}$ This significant East Indian population is in no way

'Joseph W. Elder, "Hinduism," Collier's Encyclopedia, 1987, 12:127-133,

${ }^{2}$ Seventh-day Adventist Yearbook (1988).

${ }^{3}$ Ibid., 327 .

${ }^{4}$ Annual Statistical Digest 1988, no. 32 (23 Park Street, Port-of-Spain, Trinidad: Ministry of Finance and Planning, Central statistical office, 1987), 14-15. 
reflected in the church membership of the South Caribbean Conference of Seventh-day Adventists.

Available statistics reveal that the national membership of the Seventh-day Adventist Church is 30,371 . This is 2.53 percent of the national population. East Indians account for 5.7 percent of the Seventh-day Aventist Church membership. However, only 2.2 percent of this membership were formerly Hindus; the majority of this group, 60 percent, came from other Christian denominations.' Because of this numerical disparity, the apparent Negro monopolization, and the strong Western conditioning of Seventh-day Adventist Christianity, the Hindus are inclined to disregard the Seventh-day Adventist Church as a foreign entity.

It should be noted that Eric John Murray mentioned nothing in his book about evangelizing the Hindus in Trinidad. $^{2}$ He, nevertheless, drew attention to the fact of their significant numbers and high percentage. ${ }^{3}$ This may be illuminated by Aaron Hitlal's observation in his

${ }^{1}$ See appendix c., for statistics supplied by the South Caribbean Conference of Seventh-day Adventists.

${ }^{2}$ The Republic of Trinidad and Tobago is a nation comprising of two islands; Trinidad and Tobago. Since the vast majority of Hindu population reside in Trinidad, while the presence of Hinduism in Tobago is a raity, this project concentrates on Trinidad only.

${ }^{3}$ Eric John Murray, A History of the Seventh-day Adventist Church in Trinidad and Tobago 1891-1981 (Trinidad: The College Press, 1982), 138. 
M.Div. thesis. He indicates that though there was an awareness of the challenges and barriers to evangelizing Indians in Trinidad, "comparatively little or no attempt was made to evangelize the Indian population." 1

Personal observation discloses that the traditional evangelistic methods as practiced in Trinidad have not met with substantial success among Hindus. Instead, in Indian communities, this type of evangelism tends to generate prejudices, hostility, and resistance, which at times have been physical. In some cases, positive response to the gospel has resulted in community and family disruption and fragmentation.

Furthermore, many former Hindus who have become Seventh-day Adventist Church members seem to have been influenced to develop an anti-Hindu attitude. In rejecting whatever in Hinduism is incompatible with Christianity, they disqualify and disregard both the Hindu religion and cultural practices which are uniquely Hindu as heathen and bad. This attitude seems to have paralyzed the effectiveness of their witness of God's saving grace.

Pastors and church members in areas of significant Hindu population have observed the relatively minute success that has resulted from evangelism, despite

${ }^{1}$ Aaron R. Hitlal, "The Origin and Early Development of the Seventh-day Adventist Movement in Trinidad and Tobago" (M.Div. thesis, Andrews University, 1973), 119 . 
the effort, time, and sincerity that have been invested. Moreover, the South Caribbean Conference seems to have little if any formal and well-defined strategy that has been developed to assist pastors and church members working with Hindus.

Consequently, a need seems to be for developing for an appropriate strategy especially designed and contextually relevant to the challenges and obstacles to the evangelizing of Hindus in Trinidad. It is anticipated that this project will make a contribution to this strategy so that pastors and church members may be informed by it so they can witness to the Hindus in the interest of their eternal salvation under the ministry of the Holy spirit and with intentionality and a degree of competence.

\section{Limitations of the Project}

This study attempts to deal with that portion of the concerns and needs of those pastors and members of the South Caribbean Conference of Seventh-day Adventists whose ministry takes them to witness among Hindus. They then can begin a process of developing and implementing appropriate ministries geared towards the Hindus. The intent is not to deal with numerous needs, concerns, and problems that confront these people in general, as viewed by the wider Christian church. 
Some aspects of the evangelistic strategy employed by the early church as is reflected in the Acts of the Apostles have been investigated. Particular attention has been placed on the conversion of groups of people or households. This has been in an effort to develop a biblical and theological basis that will inform a strategy for evangelizing the Hindus in Trinidad. The benefit of selected literature on cross-cultural ministries, church growth, and missions in India is brought to impact on this study.

Because the Sanaatan Dharma Mahasabha is the numerically dominant and the most influential of the Hindu sects in Trinidad, it is the sect that this study addresses. It is hoped that Hinduism as a whole in Trinidad can be impacted by the strategy developed.

It should be noted that this study is not designed to be a standardized manual for evangelizing Hindus. Instead, it attempts to provide principles and models which will form the parameters within which some creativity, innovation, and experimentation can take place. Therefore, a variety of situations posed by the Hindu communities can be addressed with some appropriateness.

Finally, it must be realized that this study is only a small part of ongoing research, experimentation, and 
strategizing designed to arrive at a situation where the Hindus are being successfully evangelized.

\section{Organization of the Project}

This Doctor of Ministry Project Report is classified by the Seminary Bulletin as Project II. Consequently, it is divided into two parts. Part $I$ is a theological position paper that studies a particular church-related problem, biblically and theologically. Part 11 deals with the same problem from the point of view of ministerial practice and pastoral concern.

Four chapters are included in the Part I. Chapter 1 is a general introduction. Chapter 2 is a theological and definitive study of evangelism that examines Jesus' evangelistic commission as recorded by Matthew. It also discusses how the apostles went about fulfilling this commission as recorded in the Acts of the Apostles. Since significant emphasis has been placed on the evangelization of households and groups among the Gentiles, Matt 10:3437 and 1 cor 9:19-22 are discussed in order to present a more balanced view of evangelism. Chapter 3 is a study of Hinduism in Trinidad, dealing with its origin, beliefs, and practices, while Chapter 4 is a review of selected, related literature on Hindu socio-cultural practices, contextualization, and evangelism of Hindus. Part II has two chapters. Chapter 5 studies recommended strategies; Chapter 6 is a general conclusion. 
9

Definition of Terms

The following terms have been defined in order to elucidate their usage in this study and thereby reduce misunderstanding and abstruseness and ambiguity.

Bhajanas: Christian hymns and gospel songs texts that have been set to certain Hindu musical forms and sung in a Hindu language are called Bhajanas; they are also called Bhajans.

Caribbean Union: The administrative structure of the Seventh-day Adventist Church that coordinates the activities of the Church in Anguilla, Antigua, Barbados, Barbuda, British Virgin Islands, Carriacou, Grenada, Guyana, Mosterrat, Petit Martinique, Saba, st. Eustatius, st, Kitts/Nevis, st. Lucia, st. Martin, st. Vincent, and the Grenadines, Surinam, Trinidad and Tobago, and the United States Virgin Islands.

Dharma: Dharma is the assigned duty of each individual in life designed for maintaining the cosmic order. When an individual performs his/her duties faithfully he or she supports the order and also is in good grace relative to the laws of karma.

Evil Eye: The belief that a person has certain supernatural powers at his or her control and can, by watching a person or object, cause harm is called the evil eye. 
Hindu Manner of Eating: When eating, Hindus may sit on mats on the floor or may sit at a long table. Men eat first and by themselves and the women eat after by themselves. The dishes are spiced with oriental spices with a substantial use of curry, gera, masala, and pepper. The meal for each person is placed on a balisier leaf about twelve to eighteen inches long and it is eaten with the fingers rather than with cutlery.

Jumbees: The alleged souls of the dead which have assumed bodily forms and interact with the living, usually to scare or harm their former enemies or enemies of their family, are known as Jumbies.

Karma: The Hindu belief in the laws of cause and effect is called Karma. The idea is that how one lives in the present life whether good or bad determines the kind of body he will inhabit in the next life.

Moksha: Moksha is the final release or liberation of the Hindu soul from this world and Samsara.

OBeah: Obeah is the belief that a person has supernatural powers at his or her disposal and can use them to accomplish whatever he or she wants whether it be for good or bad.

Puja: The worship of a Hindu deity at the home, the temple or any other designated place, when offerings and prayers are made is called Puja. 
Pundit/Pandit: Both terms refer to a Hindu priest and teacher of Hindu theology and philosophy.

Sari: The Sari, standard dress of the Hindu woman is comprised of about six yards of selected cloth that is carefully and skillfully wrapped around the body.

Samsara: The experience of the Hindu in this life where the soul is entrapped in the cycle of passing from one body at death to another at birth in an apparently ongoing process is known as Samsara.

South Caribbean Conference of Seventh-day Adventist: This title is given the administrative unit of the Seventh-day Adventist Church that is responsible for and coordinates all the activities of the church in the Republic of Trinidad and Tobago.

Sukuya: Sukuya is alleged to be an older person who, during the night, sheds his or her skin and flies around sucking blood from people or their livestock. After such an expedition the person returns home before the dawn, replaces the skin, and processes the blood that was collected during the night. 


\section{PART I}

A BASIC THEOLOGY OF EVANGELISM AMONG THE HINDUS IN THE REPUBLIC OF TRINIDAD AND TOBAGO 
CHAPTER II

\section{DEFINITION AND THEOLOGY OF EVANGELISM}

\section{Introduction}

Here, an attempt is made to develop a brief biblical theology of evangelism. In order to appropriately move in this stated direction, a working definition of evangelism is established. An examination of selected biblical instructions regarding evangelism is made to establish the fact that evangelism involves more than a particular gospel encounter. Instead, it is established that the life and mission of the church is in fact and truth evangelism. Therefore, every activity of the church and every member of the church should be seen as participating in evangelism.

The evangelistic commission of Matt 28:18-20 is scrutinized in order to better understand its meaning and inherent instructions. Following that, an investigation of the apostolic response to the gospel commission is undertaken. Emphasis is placed particularly on methods employed while working among the Gentiles. The intent is to identify a strategy that the apostles used. It is noted that primary emphasis was placed on the conversion 
of a family group or an influential person in the given setting. Matt 10:34-37 is brought to bear on the discussion to demonstrate that if the method of salvation by group fails, then the salvation of the individual becomes the exclusive alternative irrespective of the potential or actual cost or consequences.

Finally, Paul's counsel in 1 Cor $9: 19-20$ is examined to instruct the church relative to the attitude necessary for the process of implementing Christ's gospel commission contemporarily and contextually.

\section{Towards a Theological and Biblical Understanding of Evangelism}

Evangelism is a word commonly used within the Christian church, but with a variety of meanings." It is important, therefore, that any definition of evangelism reflect the biblical derivation and intent of the word. Though this word is not explicitly used in scripture, it appears in other grammatical forms and is obviously implied and is the embodiment of the Gospels, particularly the Acts of the Apostles. Evangelism is derived from the

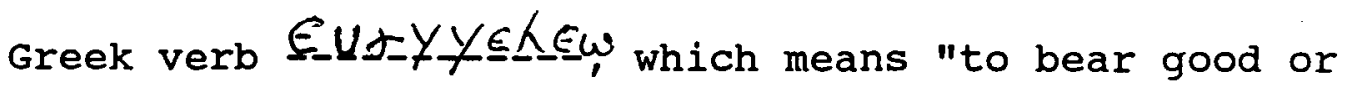
positive news." This verb in its variant forms occurs fifty-four times in the New Testament. The noun in its

\footnotetext{
'Richard Stoll Armstrong, The Pastor as Evangelist (Philadelphia: Westminster Press, 1984), 23-26.
} 
variant forms occurs seventy-six times in the New Testament. ${ }^{1}$

originally the noun was used to refer to the reward that was extended for the receipt of good news. Subsequently, the reward aspect was dropped and the word came to denote the actual good news. ${ }^{2}$ Aseudyyehlov entered New Testament literature, it now

denotes the "good tidings" of the kingdom of God and of salvation through christ, to be received by faith, on the basis of $\mathrm{His}$ expiatory death, His burial, resurrection and ascension. 3

Therefore, evangelism can be defined as the process of carrying "the good news," the gospel, throughout all the world in order to give every person an honest opportunity to understand it and accept Jesus as Savior and Lord. Each person may then experience a resulting change in life. Johnson subscribes to this view when he suggests that evangelism is

that particular task of the church to communicate the good news of God's love to persons so that they may understand the message, place their trust in Christ, become

'Institute for New Testament Research and Computer Center of Muster University, ed., Concordance of the Novum Testamentum Grace, 3rd ed. (Berlin: Walter De Gruyter, 1987), 722-723.

${ }^{2}$ W. E. Vine, An Expository Dictionary of New Testament Words (Nashville: Thomas Nelson Publishers, 1985), 275.

${ }^{3}$ Ibid. 
loyal members of his church, and fulfill his will as obedient disciples.

As one looks at the Bible, it seems that John the Evangelist had evangelism under contemplation when he wrote his gospel, for he concluded with:

But these things were written that ye might believe that Jesus is the christ, the son of God; and that believing ye might have life through his name.

Evangelism, therefore, is of solemn importance. This fact has been substantiated by the prominence that has been given to the proclamation of the gospel, especially throughout the New Testament. It is important to note that in Matt 28:18-20; Mark 16:15-16; Luke 24:45-49; John 20:21-23; Acts $1: 8 ;$ and Rev 14:6-7 specific instructions are given relative to the proclamation of the good news of salvation to everyone everywhere:

The successful realization of the intent of this command is largely dependent on the church's active involvement under the ministry of the Holy spirit. Since everyone should be encountered with the gospel, this seems to suggest that evangelism has to be a continuous process, for only the Second Advent of Jesus can terminate it. Matthew, in his gospel, lends support to this position when he quotes Jesus as having said that "the

\footnotetext{
'Ben Campbell Johnson, Rethinking Evangelism: A Theological Approach (Philadelphia: Westminster Press, 1987), 12 . 
gospel of the kingdom shall be preached in all the world for a witness unto all nations; then shall the end come." In addition to this, after setting an honorable example of genuine evangelism, Paul came to the end of his life with a sense of accomplishment. In delivering to Timothy his final charge, Paul carefully instructed him to evangelize continuously. He concluded by suggesting that vigilance and evangelism results in a fulfilled ministry. ${ }^{2}$

Therefore, the church which includes every member should recognize evangelism both as an inescapable life time responsibility and as a way of life. It has been stated that

The church is God's appointed agency for the salvation of men. It was organized for service, and its mission is to carry the gospel to the world. From the beginning it has been God's plan that through His church shall be reflected to the world His fullness and His sufficiency. The members of the church, those whom He has called out of darkness into $\mathrm{His}$ marvelous light, are to show forth $\mathrm{His}$ glory.

This approach ensures the continuity needed in order to evangelize everyone, everywhere. It also removes the possibility of confining evangelism to the proclamation encounter by one officially recognized as an

\footnotetext{
'Matt $24: 14$

${ }^{2} \operatorname{Tim} 4: 1-5$.

${ }^{3}$ Ellen $G$. White, The Acts of the Apostles
} (Mountain View, California: Pacific Press Publishing Association, 1911), 9. 
evangelist. Instead, it becomes a team effort where the church under the guidance and the ministry of the Holy spirit harnesses all its gifts and talents for the salvation of humanity.

In this process of operation, evangelism includes three developmental stages. First is the initial preparation and the establishing of a non-threatening, trusting relationship with the evangelistic prospects. second follows the actual proclamation or formal presentation of the gospel. Third, often forgotten but important, is the feature of establishing fellowship and equipping for service through both the coordination and implementation of all the ministries of the church for the evangelizing of others. Such a holistic process should always be kept intact. Jesus, the model evangelist, exemplified this kind of evangelism; it has been reported of Him that He

mingled with men as one who desired their good. He showed His sympathy for them, ministered to their needs, and won their confidence. Then He bade them, "follow me."

In addition to Jesus's dynamic example in evangelism, He made sure after His resurrection to issue the gospel commission. He instructed His disciples both present and future to continue participating in

\footnotetext{
${ }^{1}$ Ellen G. White, The Ministry of Healing (Mountain View, California: Pacific Press Publishing Association, 1942), 142 .
} 
evangelism. Peter, Philip, Paul, and the other disciples faithfully complied. The church down through the ages has been following the apostles' example even though at times with abated zeal. The challenge has been passed on to the Church of today to communicate the gospel to everyone, everywhere so that men and women may hear and believe and be saved.

Evangelism is biblical. It has always been a living and dynamic reality in the experience of every believer. However, the entire process should always be kept intact and operative if the aims of evangelism are to be realized.

\section{Jesus' Evangelistic Commission}

\section{Introduction}

The final commission of Jesus to His disciples is recorded in all four Gospels and Acts (Matt 28:18-20; Mark 16:15-16; Luke 24:45-49; John 20:21-23; and Acts 1:8). Because Matthew's record seems to be the most detailed and comprehensive, it has been selected for use as the basis for discussion here. Due to the limitations of this project report, an exhaustive exegesis of Matt 28:18-20 is impossible. Therefore, an attempt is made to use the benefits of exegesis to arrive at a practical though less than exhaustive understanding of the commission of Jesus. In order to achieve such a goal, it is necessary to examine selected key words and phrases of 
Matt 28:18-20. The understanding gained should be instructive for evangelism today.

\section{Setting}

Jesus had been resurrected. In obedience to an earlier instruction, His disciples assembled in Galilee. There Jesus met with them. In response to His presence, the disciples worshipped Him, though some doubted. ${ }^{1}$ The fact that they worshipped Him suggests that they recognized Him as their divine Lord. Then, as they waited on Jesus to speak to them, He issued what has come to be considered the "great commission." Matthew's record of it states:

...All power is given unto me in heaven and in earth.

Go ye therefore, and teach all notions, baptizing them in the name of the Father, and of the Son, and of the Holy Ghost:

Teaching them to observe all things whatsoever I have commanded you: and, lo I am with you always, even unto the end of the world. Amen.?

Jesus began this commission with a word of assurance and encouragement. "All power"--power of a universal dimension--was at $\mathrm{His}$ disposal. The Greek word used here is better translated "authority." Like the Father, this authority that Jesus had received was inherent, intrinsic authority, given by virtue of His

1Matt $28: 17$.

${ }^{2}$ Matt $28: 18-20$ 
divinity. But it was bestowed in that He had triumphantly accomplished his mission as messiah and savior. This power was in contrast with that which had previously been given in limited proportions as the particular situation demanded. Jesus then had ultimate, absolute authority unaffected by time and space. Apart from any difference that resulted by virtue of $\mathrm{His}$ incarnation and triumph as savior, this authority was quite similar to that authority that He voluntarily laid aside from the time of $\mathrm{His}$ incarnation. Nichol puts it this way:

...that authority had been voluntarily limited. Now He once more had all the authority as before, He came to this earth to assume the limitations of humanity.

Based on that kind of authority and their relationship with Jesus, the disciples had the faith and the confidence that whatever they needed He would never withhold. Therefore, the power Jesus had, they had. They could go with all power to all nations and teach all things.

Go

"Go" is a translation of the Greek JIOPLOUEVTES -. It is a past nominative masculine plural aorist participle. Therefore, a more literal rendering could be "you having gone." This suggests a completed action or an

1"Power" [Matt 28:18], SDA Bible commentary, ed. F. D. Nichol (Washington, D.C.: Review and Herald Pub. Assn., 1980), 5:557. 
action to be completed before a further and related action can be carried out. In other words, it facilitates the occurrence of further action. Consequently, in this text under consideration, "you having gone" should both precede and be completed before the action of the main verb (make disciples) can take place. Thus, before the disciples of Jesus can do anything in the process of evangelism, they must first go.

This participle "having gone" is also qualified by the pronoun "you," which by implication pertains to the imperative "make disciples." In addition, further study reveals that similar grammatical structure in which this word is used in other books of the Bible, including Matthew, allows for its translation as an imperative. Such a translation seems appropriate here. Having cited a number of texts in both the old and New Testaments, with their preferred meanings, Rogers concludes that the participle is directly related to the main verb which is an imperative. Furthermore, the action of the main verb cannot be realized in the absence of the participle. ${ }^{1}$ Therefore, the participle not only participates in the fulfilling of the main verb but also assumes its characteristics.

\footnotetext{
${ }^{1}$ Cleon Rogers, "The Great Commission," Bibliotheca Sacra 130, no. 519 (July \eptember 1973): 260-262.
} 
In applying these principles to the Matthew 28:19 passage it seems that there is a command to go. Without the going, the making of disciples is not possible, and especially when "all nations" is the object. The participle is not to be weakened to a secondary option which is not important. The aorist aspect makes the command definite and urgent.

If the conclusion is accepted that "go" is seen as an imperative, the natural question that arises is, Where were the disciples to go? The Acts of the Apostles gives the answer as related to the Twelve, and by extension and application to all succeeding disciples. In repeating the commission in Acts, Jesus said, ". . . Jerusalem and in all Judea, and Samaria, and unto the uttermost part of the earth. ${ }^{2}$ By extension and application, the disciples were to go wherever people were. They were to go to towns and villages, to cultures, languages, and customs, to individuals, to families, and to all closely knit people groups everywhere.

The disciples were to go to the people and to remain there as long as disciples were being made. This would indicate that the "having gone" was being maintained in an on-going state of completion and would allow them to identify with their evangelistic prospects, to be able to communicate with them on a level of mutual trust and

\footnotetext{
${ }^{1}$ Ibid.

${ }^{2}$ Acts $1: 8$.
} 
respect. Then, having gone, the disciples would then be ready to do whatever else was required by the commission.

Make Disciples

In Matt 28:19, the word translated "teach"

should be more accurately rengered "make disciples." This

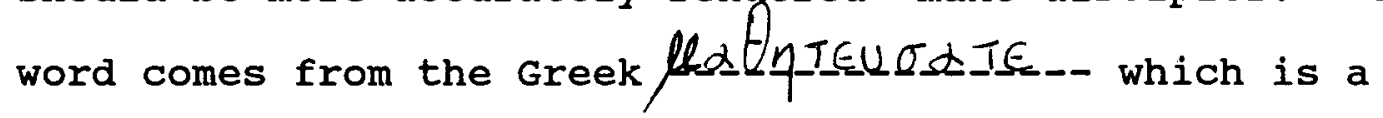
second person plural aorist imperative. The context seems to suggest that this imperative is cohortative, indicating that it is a definite command. Therefore, the more literal translation is "disciple." But

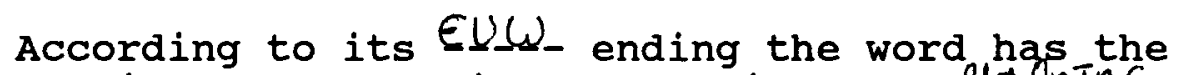
meaning, "to practice the duties of a ladyIns-, that is, to be a disciple. The word can also have, a causative meaning, to make a disciple. 1

Despite the urgency and the force of the command, Jesus does not discuss methodology with the disciples. Presumably, the disciples would have known this from their own experience with Jesus and from their acquaintance with the rabbinical tradition of discipling. That being so, discipling, or the making of disciples, could be seen as a process that the disciples facilitate rather than something the disciples do exclusively and independently. At least two persons must be actively involved, for, according to Muller,

A man is called a mathethes when he binds himself to someone else in order to acquire his

$$
{ }^{1} \text { Rogers, } 263
$$


practical and theoretical knowledge. He may be an apprentice in a trade, a student of medicine, or a member of a philosophical school. One can only be a mathethes in the company of a didaskolos, a master teacher. . .

The teacher who facilitated the process of discipling had been experiencially discipled. He had successfully undergone the rigid experience of being discipled and, consequently, was efficient and skilled in his discipline. Consequently, he was viewed as one with wisdom and authority and qualified to accept students who were allowed to tread the path he trod. The close relationship and interaction between student and teacher in the discipling process is demonstrated in the fact that The students lived in close fellowship with their teacher. They travelled with him, attended weddings or festive occasions with him. The students of a teacher were characterized by complete submission to the authority of the teacher, as well as by a devotion to him which was to surpass devotion to father, or mother and which displayed itself in service to the teacher. The teaching or learning method was to sit at the feet of the teacher listening to him, to engage in a question and answer encounter with the teacher; to observe the actions of the teacher especially as he conducted himself in regard to the law or solved problems of conduct through his knowledge of the law and the tradition. After the strenuous studies the student was ordained through the laying on of hands and received the right to be called Rabbi. He then had the responsibility to pass on that which he had learned from his teacher and to make disciples.?

'D. Muller, "ll $\alpha \theta$ nT's's" in The New International Dictionary of the New Testament, ed. Colin Brown (Grand Rapids, Michigan: Zondervan Publishing House, 1986), $1: 484$. 
Though the disciples of Jesus followed this procedure in essence, they were never to become Rabbis, since Jesus is the true teacher and Christian growth is an ever ongoing process. No disciple ever came to the point where he or she was through with discipleship, unless he or she had abandoned the Lord. As each disciple was making disciples of others, he was constantly being discipled by Jesus the Messiah and Master Teacher. Furthermore, it has been noted that there were certain differences between the qualification for Jesus' disciples and the relationship with Him as compared with the rabbinical model.

With reference to the disciples of Jesus, they were called by Him; He was the one who took the initiative. Even though it may be suggested that there were those who were attracted to Him, nevertheless, He made the final decision as to those who were to be His disciples. Relative to the rabbinical system, the individual decided to be a disciple and presented himself as a disciple to the teacher he chose.

The disciples of Jesus experienced a personal relationship with Him. They were attracted to Him as a person, not only to His teachings and activities. On the other hand, the rabbinical disciples, respected the knowledge and ability of the rabbis and related to them on a professional level. The relationship was task-oriented rather than person-oriented. 
Discipleship was the destiny of Jesus' disciples. They eternally depend on Him, therefore, He is always indispensable. For the rabbinical disciples, disciple- ship was a transitory step to a greater position. The goal of the rabbinic students was to become a rabbi, perhaps even superior to their rabbi and, consequently, independent of him.

Jesus' disciples participated only in His work and mission, while those of the Jewish rabbinical system had their personal mission and agenda which was not required to have any bearing on that of their rabbi, since they eventually would have become rabbis.

The disciples of Jesus related to Him as the Messiah, while the disciples of a rabbi related to him only as one teacher out of many. 1

Thus, from the concept of discipling, the "going" was vital and primary to the process. Each disciple was never fully made nor was he ever to finish making other disciples. It was, in fact, a perpetual inservice training program.

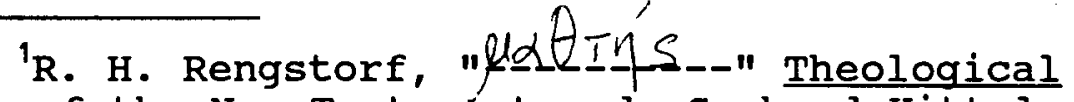
Dictionary of the New Testament, ed. Gerhard Kittel (Grand Rapids, Michigan: William B. Eerdmans Publishing Company, 1967), 4:444-450. 


\section{All Nations}

The phrase "all nations is commonly used in different places in the Bible with different meanings. In the text under consideration, there is some disagreement as to the meaning. Basically, three positions are held.' The first advocates that "all nations" refers only to dispersed Jews in Gentile countries. ${ }^{2}$ The second position argues that this phrase refers to all people everywhere, excluding the Jews. ${ }^{3}$ The third position, which o'Brien supports, suggests that "all nations" is an all inclusive phrase embracing every one, both Jews and Gentiles, and excluding no one. 4

Though Matthew has not used the phrase consistently, the context seems to suggest the allinclusive concept. Earlier Jesus had issued a command to His disciples to minister specifically to the Jews and here, this phrase was not used. ${ }^{5}$ In Mark's record of the gospel commission, the object of evangelization has been rendered "every creature," 6 which suggests the all-

${ }^{1} \mathrm{P}$. T. O'Brien, "The Great Commission of Matthew 28:18-20," The Reformed Theological Review 35, no. 3 (1976): 73-74.

${ }^{2}$ Ibid.

${ }^{3}$ Ibid.

${ }^{4}$ Ibid.

${ }^{5}$ Matt $10: 5,6$.

${ }^{6}$ Mark 16:15, 16. 
inclusive concept. Furthermore, when Jesus reiterated the gospel commission in Acts, He mentioned that they were to witness in Jerusalem, which was Jewish; Samaria, which was half Jewish and half Gentile; and the uttermost parts of the earth, including everyone else.' In addition, Paul, Peter, John, and the other disciples made disciples of both Jews and Gentiles as they responded positively to the gospel commission.

The evidences considered seem to allow for the conclusion that "all nations" is an inclusive term embracing everyone everywhere. Then everyone is to be encountered with the gospel so that he or she can have a fair chance to make a decided response to the claims of the gospel.

\section{Baptizing}

The scope of this paper does not allow for a discussion on the baptismal formula nor the mode of baptism. What is important to note here is that the texts which record the gospel commission in the synoptics, and the practice of the disciples in fulfilling this commission, seem to suggest believers' baptism.

Baptism can be seen here as an act of obedience to the requirements of the gospel commission. It is also demonstrative of an experience relative to the reason for,

\footnotetext{
${ }^{1}$ Acts $1: 8$
} 
the purpose of, and intent of the gospel through Jesus. In addition to that, it is declarative of a decision to remain a disciple for the future.

Finally, baptism can be seen here as initiative, for it is the means by which one enters into Jesus' body, the church, the redeemed community. ${ }^{1}$ This is a community of those who are being discipled while they are discipling others.

\section{Teaching}

$\delta\left(\delta_{\alpha \sigma K \sigma}\right.$

Teaching is derived from the Greek, accept, to extend the hand to). The reduplicated stem and inchoative suffix convey the idea of repeatedly extending the hand for acceptance; the word therefore suggests the idea of causing some one to accept some thing.

It is also clear that the word is used typically for the relationship between teacher and pupil, instructor and apprentice. What is taught may be knowledge, opinions or facts, but also artistic and technical skills, all of which are to be systematically and thoroughly acquired by the learner as a result of repeated activity of both teacher and pupil. ${ }^{2}$

This concept appears to reflect the rabbinical

discipling process where teaching was not merely an

intellectual process. It consisted also of the rabbi or teacher facilitating and directing the disciple's

\footnotetext{
'J. K. Howard, New Testament Baptism (London: Pickering and Inglis, 1970), 61.

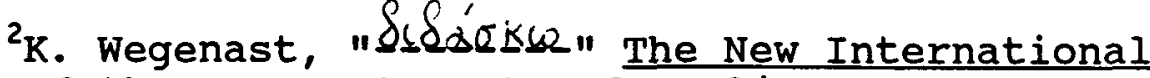
Dictionary of the New Testament, ed. Colin Brown (Grand Rapids, Michigan: Zondervan Publishing House, 1986), $3: 759-760$.
} 
lifestyle similar to his own. Therefore, this has been a continuous process in which a disciple is required by Jesus to teach those he was discipling by precept and by example. It was supposed to be a repetitive process to insure that proper understanding, learning, imitation, and change were taking place in the life of the one being discipled.

\section{All Things}

"All things" probably included not only what Jesus actually said and did during His earthly ministry; it also included the entire old Testament as it related to Jesus' and, even more specifically, to God's will for all mankind, as it is enunciated in the law and the prophets and manifested and amplified in the authoritative teachings and ministry of Jesus. ${ }^{2}$ In addition to that, due to the fact that the New Testament is also the revealed will of God and participates in the canon, then it also has become a part of the "all things" that Jesus commanded them to teach.

Conclusion

An examination of the commission of Jesus seems to indicate that evangelism is an all-embracing, on-going

\footnotetext{
${ }^{1}$ Luke $24: 27$.

${ }^{2}$ Jacques Matthey, "The Great Commission of Matthew," International Review of Mission 69, no. 274 $(1980): 171$.
} 
activity of the church. In the first place, those who respond to the command must recognize and be encouraged by the fact that Jesus not only has all power to command; in addition, He enables and empowers those who respond in carrying out His mission.

The primary task of Matt 28: $18-20$ is to make disciples of all nations. However, prior to that the disciples must go to where the people are--they are to go to all nations. Furthermore, they are to make disciples by teaching and baptizing. However, each disciple should recognize that discipleship is his destiny and that he is being discipled by Jesus while he is discipling others on behalf of Jesus.

Though the task is great and there may be problems, Jesus has promised that He is with His disciples unto the end of the age. Therefore, because Jesus has all power, because He has commanded, and because He is ever present, the true disciple can do none other but to evangelize. The process should impact on everyone everywhere, so that all of humanity have the privilege of being able to make a fair choice of being discipled.

\section{An Evangelistic Strategy from The Book of Acts}

Introduction

The Acts of the Apostles provides the initial data about the fulfilling of Jesus' gospel commission. However, because the process utilized was complex and had 
numerous component parts, it has become convenient to select certain of the evangelistic events for observation and discussion.

First, a convenient working context for the book of Acts is established. Next, the selected evangelistic events that occurred in Jerusalem, Judea, and Samaria, and the uttermost parts of the world are examined. In other words, the evangelistic methods used to reach Jews, Samaritans, and Gentiles are given just enough attention to assist in arriving at a basic strategy that was used by the apostles. It is expected that this will inform the development of a current and relevant strategy for evangelizing Hindus in Trinidad.

The Book, Acts of the Apostles

An overview of the book seems to indicate that the author's intention was not a chronologically historical account of the origin, development and expansion of

Christianity. Nor was his burden a development of theology or the theologizing by the apostolic church. Instead, it appears that he listed selected accounts of incidents and events. These were designed to demonstrate the ministry of the Holy spirit in the lives of the disciples and in given situations in the process of fulfilling the great gospel commission issued by Jesus. 
This book may be divided into three sections based on the geographical directions found in Acts 1:8. These may include: ministry in Jerusalem, Acts 1:1-8:3; ministry in Judea and Samaria, Acts 8:4-12:25; and ministry to the uttermost parts of the earth, Acts 13-28. Luke also notes some of the pangs and challenges of growth, expansion, and the assimilation of new members by the church. In this process, one is able to note the transitional character of the narrative in chs. 8 to 12 , where the church is widening its horizon and is receiving into its membership other than Jews, and so is being prepared for its universal mission.

From a small beginning the Church appears to have soared to new dimensions numerically, spiritually, and geographically. As a result it has been said concerning the impact of the disciples mission that they "have turned the world upside down." ${ }^{2}$ Furthermore, when Paul wrote to the Colossians, he mentioned that the gospel had been preached to every creature under heaven. ${ }^{3}$

\section{The Commission}

Acts 1:8 couches another rendering of the great commission recorded in Matt 28:18-20. However, a certain emphasis here is on the avenue by which the gospel is to

\footnotetext{
'Charles R. Erdman, The Acts (Grand Rapids,
} Michigan: Baker Book House, 1983), 16.

${ }^{2}$ Acts $17: 6$.

${ }^{3} \mathrm{Col} \mathrm{1:23.}$ 
reach the uttermost parts of the earth. It is quite possible that Luke would have had a purpose in mind by listing first Jerusalem, where they were; then Judea, that was substantially Jewish; then Samaria, which was half Jewish and half Gentile; and finally to the uttermost parts of the earth. In this version of the commission, there seems to reside the zygote for the evangelistic strategy that successfully evolved in Acts. This strategy basically seems to say, move from the known to the unknown with all the concomitant implications.

\section{Strategy Defined}

Before the strategy of Acts is examined, it is important at this point to establish a working definition of "strategy" that is appropriate to this project. A strategy does not and should not deal with specifics and details which are dovetailed for particular situations or operation. Instead, it is the broad framework that establishes the basic principles and parameters within which activities or services can take place in order to achieve a particular result or reach specific goals. In other words:

A strategy is an overall approach, plan, or way of describing how we will go about reaching a goal or solving a problem. It is not concerned with details. . . . a way to reach an objective, time, and place when things will be different than they are now.

'Dayton and Fraser, 16. 
Because of its overarching effect, strategy allows enough room for creativity and innovation that are homologous to the given context. This definition allows for the possible discovery of an evangelistic strategy that was used by the apostles, which might have guided their selection of pragmatic evangelistic methods and approaches. As a result, an evangelistic strategy for this paper can be appropriately informed.

\section{Ministry in Jerusalem (Acts 2-7)}

The apostles' response to the gospel commission began at Jerusalem and to the Jews in particular. Chosen incidents from that setting are examined to illustrate the methods they used.

\section{At Pentecost (Acts 2)}

At Pentecost, the apostles seem to have been strategically poised at the right place at the right time. They were assembled, quite likely within the precincts of the temple. To this location were streaming Jews from varying cultural and linguistic backgrounds. For it has been reported that

During the dispersion, the Jews had been scattered in almost every part of the inhabited world, and in their exile they had learned to speak various languages. Many of these Jews were on this occasion in Jerusalem, attending the religious festivals then in progress. 
Every known tongue was represented by those assembled.

As Peter sought to demonstrate that the crucified, buried, resurrected, and ascended Jesus was in certainty the Messiah, he appealed to David for needed authentication and validation of his argument. David was considered a symbol of monarchial success. Peter appealed to Jewish national pride and hope of deliverance from Roman hegemony. The messianic reign and throne were in David's name. David was highly esteemed by just about all Jews. Therefore, if what had happened to Jesus was prophesied by David, who also said that Jesus is the Messiah, then chances were that the Jews would accept Jesus and be saved. Furthermore, Peter used Joel who was not one of the prophets who was constantly critical of Israel and its sins. As a result, over 3,000 persons became members of the church. Then an adequate support system was set up. This was comprised of welfare programs, regular congregational worship, house-to-house fellowship, and evangelistic out-reach to others. Consequently, the church continued to grow.

It should be pointed out here that although luke mentioned that the new believers met in the temple, which is important, he also stated that they met from house to house. This suggests that the house meetings were not

${ }^{1}$ Ellen G. White, Acts of the Apostles, 39. 
only equally important but they were both so out of the ordinary and significant that it became necessary to mention them as a separate activity. Could it be that these house meetings indicated not solely meeting in a building but also implied the meeting of the families or households which were saved?

\section{Solomon's Porch (Acts 3, 4)}

The next evangelistic event that is considered again occurred within the temple confines at around three o'clock in the afternoon. The time, place, and possible corresponding attitude of the people then present seemed to have made the occasion most opportune for their being evangelized.

A miracle attracted the people's attention and aroused their curiosity. Peter seized the initiative and preached "the resurrected Jesus as the only means of salvation." In doing this, Peter summoned the witness of the patriarchs: Abraham, Isaac, and Jacob in whose ancestral line the Jews prided themselves as being extraordinarily privileged. He also appealed to Moses the prophet par excellence. With such support and appropriate audience identification and appeal, he pointed out their sins, including that, through ignorance, they had crucified Jesus. Then he invited them to repent in light of the fact that many other old Testament prophets had proclaimed that they were chosen, they were the recipients 
of the covenant of promise. As a result Jesus wasresurrected to bless them. That sermon created confusion among the religious leaders who had the apostles arrested and tried. The apostles used this trial to further preach Jesus.

Stephen (Acts 6: 8-7: 60)

At the stoning of stephen, the audience might have been assembled somewhere within the compound of the temple. Stephen was before the council, on trial for his witness. As he was authorized to defend himself, he publicly preached a historical sermon, the facts of which were pertinent to his hearers, for it was their history. In doing so,

He showed a thorough knowledge of the Jewish economy, and the spiritual interpretation of it, now made manifest through christ. He repeated the words of Moses that foretold of the Messiah: ${ }^{1}$

This sermon aroused such anger among the Jews that stephen was martyred before his sermon was through. In spite of this apparent tragedy, the church was sustained and God was able to bring some good out of it in that the church continued to grow. ${ }^{2}$

\footnotetext{
'Ellen G. White, Acts of the Apostles, 99. 2Ibid., 101, 102 .
} 
Conclusions

As examination of the ministry of the disciples among the Jews reveals that they were both methodical and organized. Their method may be outlined thus:

1. The apostles were subject to the ministry of the Holy spirit in their lives.

2. They were, therefore, at the right place at the right time.

3. They went where the people were and allowed the gospel encounter to take place where and when it was convenient to the people for their evangelization.

4. They identified with the people.

5. The sermons were contextually relevant and the illustrations and burden of proof were based on sources, whose credibility, all then present, respected.

6. Tragedy or misfortune were not perceived as deterrents to the progress of their mission.

$$
\text { Ministry in Judea and Samaria }
$$

Strategic Reorganization (Acts 6: 1-7)

As the Church grew, two prominent groups emerged. These were the Hebrews and the Grecians. The Hebrews were Jews who lived in Jerusalem, and who spoke Hebrew. The Grecian Jews lived 
out in the Roman Empire, and learned Greek, so they were Greek-speaking Jews.'

It would appear that the Hebrews were in the leadership positions and for some reason did not adequately minister to the needs of the Grecians. The issue of "serving at tables" might have been only the presenting problem of a deeper or more fundamental issue.

To deal with this challenge, seven men of high ecclesiastical credentials were chosen. They all had Greek names. Though there were Hebrews like Andrew with Greek names, there appears to be a difference here. In the first place, similar to the case of the Twelve, the naming and commissioning of the seven is immediately followed by an account of their ministry. Next, their selection was a response to a particular problem. Then Luke notes that the "word" and the Church grew following this response. ${ }^{2}$

It has also been argued that

Probably the Hellenists were discovering that their view of the gospel was not quite that of the Palestinian brethren, and they wished apostles of their own who would represent it. This title "the seven" corresponds to the title "the twelve," and the names of the seven are given in full like those of the apostles. The

${ }^{1}$ Manford George Gutzke, Plain Talk on Acts (Grand Rapids, Michigan: Zondervan Publishing House, 1966), 71.

${ }^{2}$ Acts $6: 7$. 
distinction between the seven and the twelve was one of sphere not one of function. ${ }^{1}$

Though one may not want to go this far, a

similar conclusion seems to be faithful to the text. That is; there was a problem with ministry among the Hellenists members. Consequently, the Church selected men who were Hellenists who were culturally alert and conversant with the concerns of these people, who at that time seemed to be the minority. This is an aspect of contextualization where an effort was made to indigenize leadership and ministry. As a result,

the word of God increased; and the number of the disciples multiplied in Jerusalem greatly; and a great company of the priests were obedient to the faith. 2

Ministry in Samaria (8: 1-13)

As a result of persecution that was intensified with the martyrdom of stephen, the Christians were scattered throughout Palestine. Philip found himself in Samaria, and there he began evangelizing his half-Jewish brethren. He most likely conducted public meetings. However, the fact should be noted here that the Samaritans hated the Jews and vice-versa. In addition, the Samaritans had rejected the Jewish theology and developed their own based on their own scripture--the

${ }^{1}$ George Arthur Buttrick, ed., The Interpreter's Bible (Nashville: Abingdon Press, 1954), 9:91.

${ }^{2}$ Acts $6: 7$. 
Peshitta, their holy mount--Mt. Gerizim, and the Messiah. Consequently, Philip's success could not have been an accident. He, being a Hellenist, may have conditioned his message to make the gospel appealing and acceptable to the Samaritans. Everett F. Harrison, however, takes the position that

Philip's message centered in "Christ." . . This means he identified Jesus of Nazareth as fulfilling the promises of the coming of God's Anointed one for whom the Samaritans looked.

As a result of his ministry, the people of Samaria believed the gospel and were baptized. Among them was one of the most influential men of that city, simon, who also was baptized, though there was some inconsistency with him, subsequently.

Emphasis should be placed here on the fact that the method of evangelism that Luke is discussing here is the people-movement approach. He seems to indicate that simon was the most prominent person in that community and he was not only baptized but followed Philip. The fact that his former life and his conversion is mentioned together with the conversion of the people of his city could suggest that his influence could have had some bearing on their decision. If he had such control over them, as Luke suggests, then normally they might not have

${ }^{1}$ Everett F. Harrison, Interpreting Acts: The Expanding Church (Grand Rapids, Michigan: Zondervan Publishing House, 1986), 144 . 
made such a dramatic decision without a struggle, which would have been important enough to mention. Therefore, his decision evidently participated in giving the people permission or in leading them to make the decision they did.

\section{Ministry in Judea (Acts 9: 32-11:30)}

Luke in Acts 8:40 abruptly concludes his account of the ministry of the seven. Again in Acts 9:32, he turns attention to the Twelve with emphasis on Peter's ministry. Peter passed through Lydda, and there the Holy Spirit used him in the healing of Aeneas. Consequently, the people of Lydda and Saron accepted Jesus as Lord. ${ }^{1}$ Then Peter went to Joppa and there Dorcas was raised from the dead. As a result, many believed the gospel. ${ }^{2}$

Next, through a series of divine interventions, Peter went to Caesarea to the home of a Gentile, Cornelius, in order to evangelize him. Though he was a Gentile, he was not considered a heathen.

Cornelius was a God-fearer. In the New Testament times this had become almost a technical term for Gentiles who, weary of the gods and the immoralities and the frustration of their ancestral faiths, had attached themselves to the Jewish religion. They did not accept circumcision and the law; but they attended the synagogue and they believed in one God and in the pure ethic of Jewish religion.

\footnotetext{
${ }^{1}$ Acts $9: 32-35$.

${ }^{2}$ Acts $9: 36-42$.
} 
Cornelius then was a man who was seeking after God, and as he sought God, God found him.

Cornelius had assembled his family and, most likely, others under his influence from the community. Peter arrived and after the formality and the establishing of mutual trust and respect, Peter proclaimed to them the gospel. That included the life, ministry, crucifixion, burial, and resurrection of Jesus the Savior, whose command it was to evangelize. The Holy spirit fell on the Gentile household and they all were then baptized, having accepted Jesus as savior.

It is important to note that this is the first recorded account of the evangelization of a truly Gentile group. Here the sermon was different. Peter did not seek the support of the old Testament witnesses. He left the burden of proof on the actual message he presented. Most likely, as far as he was concerned, he was just presenting undeniable authoritative facts under the power of the Holy spirit. As a result, not a city nor a large number of individuals, but a closely knit and cohesive group--a household or family--was baptized together. This was not to be a unique phenomenon, since, subsequently,

Conversions of groups were quite common in the early days of the church, and the church in the house had a cohesive strength because it was not merely an aggregation of individuals who happened to gather periodically in a certain

${ }^{1}$ William Barclay, Acts of the Apostles (Philadelphia: Westminster Press, 1976), 79. 
house; rather, it involved many who had already been associated but now found that association deepened by the transforming power of the gospel.

In this first account, the gospel was being presented to what may be called pure Gentiles. Luke notes at the beginning of the encounter that the household was assembled together. He concludes by stating that the Holy spirit fell on them all and they were baptized, subsequently. This seems to indicate that a different method has been introduced for a different audience. This method is not the conversion of the individual but rather of the household or family. Therefore, no stated support system was set up since a household was baptized. In such a situation, the needed support and encouragement seemed to be a natural spontaneous result, since churches were established in homes like this.

\section{Ministry to the Uttermost Parts of the Earth (Acts 13-20)}

From Acts 13 and continuing, Luke concentrates on evangelizing the uttermost parts of the earth. Here everything seems to revolve around Paul whom God had chosen and separated to be His servant to the Gentiles. In his initial ministry, Paul attempted to evangelize both Jews and Gentiles. It seemed that as a custom, he met with the Jews in the synagogues. However, he met with the

\footnotetext{
${ }^{1}$ Harrison, 268.
} 
Gentiles wherever they were. As the venues varied, so did the method of evangelization.

By the Riverside (Acts 16:14, 16)

Lydia was evidently a woman of the upper socioeconomic strata of society. She seemed to have been a regular participant in an ongoing prayer group which met by a riverside. There Paul and his contingent met with this group on the Sabbath day. He preached the gospel and, as a result, Lydia and her household believed and were baptized.

This account begins with Lydia in the context of a religious group and concludes with her in the context of her family. Since the burden of Luke seems to be the growth and progress of the church, then the conversion of Lydia and her family was the focal point of this account. The other issues discussed were probably designed to create the scene in which this conversion took place. This is apparently a deliberate attempt at highlighting a family or household conversion. In Acts 10, Luke presented an average household which was extended and where Cornelius was head of the house. In Acts 16: 14, 15, Luke highlights the conversion of a probably less prestigious family, a single-parent family where the woman was head of house. It can be concluded that the size or type of family is of little consequence, saving them by 
the group method is what is important and most likely will work.

The Philippian Jailer (Acts 16:16-34)

Paul and Silas had been imprisoned because their ministry adversely threatened the economy of a few wealthy citizens. Due to their Christian witness and the effects of the earthquake while they were still imprisoned, an opportunity was created and interest was aroused for the presentation of the gospel. The effect of this evangelistic engagement was that the jailer and his household were converted and baptized.

Here again, the pivotal point is the salvation of another family. This time it seems to be a family headed by a man who was probably stern, firm, and uncompromising. He was the one who was witnessed to initially and, subsequently, his entire household believed and were baptized together with him as evidence of their conversion.

\section{Athens (Acts 17:15-34)}

with some time on his hands, Paul made an analytical observation of the religious practices and symbols in Athens. At the same time, it appeared that he also held dialogical engagements with those assembled in the synagogue and at the academic and political forums, concerning the gospel. That aroused some curiosity and, 
as a result, Paul was invited to the Areopagus. There he preached the gospel, contextually, since he was quite knowledgeably informed about his audience.

The moment Paul began his sermon, it was evident that he had done his home work.

He began by making two points about them. He first recognized that his hearers were basically religious, but in the same breath claimed that their religion was based on ignorance, He was able to substantiate his assessment by what he had seen in their city.'

As the apostle developed his sermon, instead of quoting from the old Testament, he appealed to gems of truth from their own literary scholars to support his presentation. ${ }^{2}$ Though some seemed unconvinced, there was some success. Despite the fact that no record testifies of a household being baptized here, Charles R. Eerdman stresses that - . one of the judges was converted, also a woman of social prominence, "and others with them." If there was any "failure" it must be attributed to the intellectual pride of his
hearers.

\footnotetext{
${ }^{1}$ Kenneth F. W. Prior, The Gospel in a Pagan Society (Downer's Grove, Illinois: InterVarsity Press, 1975), 64 .

${ }^{2} \mathrm{~L}$. Legrand, "The Unknown God of Athens," Vidyajyote 45 (May 1981): 226. "We are indeed his offspring" is a text of Arastus of Soli. Arastus, born c. $310 \mathrm{BC}$, was a friend of Zeno the stoic, and "his writings show considerable stoic influence." The words quoted in Acts 17:28 are taken from the prologue of his phaenomena. "In him we live and move and have our being," This verse has been traced back to Epimenides, a more ancient and hoary figure.
}

${ }^{3}$ Erdman, The Acts 141 . 
Carl F. Henry accounts for Paul's success this way:

If only a few Athenians believed, that cannot be blamed on Paul's procedure here. Certainly we agree with the statement that "the preaching comparatively failed at Athens, not because of the preacher's method, but in spite of it." "

In this salvation episode, a household is not

saved. Nevertheless, the people-movement or groupsalvation principle is in operation. Luke indicates that two prominent persons, one male, one female, believed and many others with them. Therefore, not isolated individuals but a group believed. This could suggest that the group's decision was evidently influenced by the two taking their stand.

Corinth (Acts $18: 1-11$ )

At Corinth, Paul tried to evangelize some Jews who were attending a series of meetings that he was conducting at the synagogue. When he presented Jesus as the Messiah, they vehemently opposed him. Consequently, he officially terminated his mission to Jews and, instead, concentrated his time and energies on the Gentiles. Thereafter, Paul started a home-church mission operation which he conducted for an extended period of time. The result of his ministry at corinth was that the chief ruler of the synagogue, Crispus, and his household believed the gospel and were baptized. Following that, many other

${ }^{1}$ Carl F. Henry, The Biblical Expositor

(Philadelphia: A. J. Holman Company, 1960), 2:215. 
Corinthians believed and were baptized--most likely as a result of the impact of this influential man's decision. In this setting, Crispus, the chief ruler of the synagogue, who was most likely a Jew, would have been ostracized had he, alone, accepted Paul's unpopular message and publicly demonstrated that fact. Luke, therefore, establishes the fact that he was saved along with his family. Together they were better able than one individual to endure any ostracism or persecution. As a result of this group-salvation principle that was applied, many more persons were baptized. Subsequently, a church was organized at corinth. Based on some of the issues Paul dealt with in his first letter to them, it seems to suggest that the church was made up of families and groups.

In 1 Cor 1, an inter-group conflict in the church is mentioned, and Paul acknowledged that he had baptized stephanas and his family. In 1 cor 7, Paul deals with family concerns. Here again, strong emphasis is placed on the group conversion in a hostile situation.

\section{Conclusion}

As evangelization of the purely Gentile communities is examined, differences in the sermon content and the methods of approach become obvious.

Among the Samaritans, Philip preached Christ, meaning the Messiah or the Anointed one. He was the 
fulfillment of the supposed, strong, messianic expectation of the Samaritans. To the Ethiopian who was apparently a partial believer, he preached Jesus, the Savior. When Paul encountered the Athenians, he preached about God the universal creator and sustainer, who will judge everyone through Jesus the resurrected one. Outstanding, however, is the fact that to the Gentile audience the apostles avoided the use of Jewish old Testament history. Neither called upon the patriarchs or Moses to substantiate their sermons. They seem to have depended on the Holy spirit and the power and relevance of their sermons.

With respect to methods--whereas with the Jews, as a general rule, the evangelization encounter took place in the synagogues, with the Gentiles the encounter took place wherever the people were. The exception to this rule occurred on occasions when the apostles had an extended stay in a particular city and a center of operation had been set up. From that location they labored for the salvation of as many persons as possible. As a general rule, however, they went to the people. Among the Gentiles, they held public meetings, cottage meetings, one-on-one Bible study. They preached, taught, dialogued, performed miracles, and witnessed powerfully by their example.

As the entire process is surveyed, two things stand out relative to the evangelization of the Gentiles. 
Usually they evangelized families or households and, to a lesser extent, the influential person or persons in the particular situation. Thus, salvation by households seem to be a very effective method of evangelism among the Gentiles. As a result, the need for a formal retentive support system was reduced, especially since, in some instances, churches were established in the homes. For example, there was a church in the house of Archippus (Phlm 2: 2), one in the house of Nymphas (Col 4: 15), and another at the home of Aquila and Priscila (1 Cor 16:19).

\section{Household $\backslash$ Family Evangelism}

The word "household," which originally meant a dwelling place, may refer to the family, the extended family, or the family and any related associates. It comes from the Greek $0 \dot{K} \leq Q S$ and is frequently used in the Bible. In discussing the derivation of this word, colin Brown suggests:

---- and----- appear very frequently in the LXX chiefly to translate the Heb. bayit. Both words denote the building. . . But because Heb. like Gk. has no word for the social unit which we call the family, bayit . . acquired, in addition to its original meaning of dwelling place, that of household (those bound together by sharing the same dwelling place), in a broader sense that of the family and clan and even that of a bigger tribal unit.

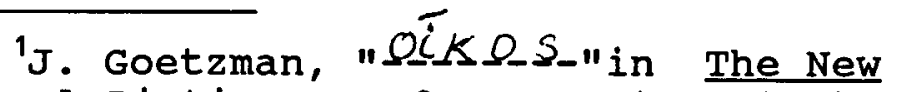
International Dictionary of New Testament Theology ed. Colin Brown (Grand Rapids, Michigan: Zondervan Publishing House, 1986), 2:247. 
In Acts, as noted above, household is used in four primary evangelistic encounters $(16: 15,31-33 ; 18: 8$; and 10:21-48). However, in Acts $10: 2$ and 21-48, the context suggests that this group included more than the biological family. According to vs. 24 , the household included other relatives and friends.

Therefore, the development of household evangelism as a distinctive method, especially among those with little or no acquaintance with the gospel and in hostile communities, is adequately exemplified and instructive. Jesus also used this method at times in His ministry. According to John 4: 1-42, Jesus encountered a Samaritan woman and began to witness to her. When her interest was aroused and she requested salvation, Jesus sent her to call her husband. In other words, because of the enmity between the Jews and the Samaritans, Jesus knew it was important to involve the family. Though she did not have a family per se, when she had accepted Jesus as Messiah, she returned to her community and called those of her group. There she witnessed to them from personal experience and did not try to teach them as one who knew more than they. As a result, many persons from her community believed on Jesus and came to Him. When they saw Him and heard Him, they too accepted Him as Messiah and Savior. 
Similarly, as is reported in Mark 5:1-20 after Jesus had healed the demon-possessed man, instead of honoring his request by permitting him to follow Him, Jesus told him to return to his family and share with them what had happened to him. ${ }^{1}$ Here, Jesus demonstrated his interest in the salvation of the man and his family. For in the hostility that resulted, it would have been difficult for the man alone to remain a follower of Jesus in that community.

Such an approach was logical because when an individual adapts a new life style or changes his religion to one that is foreign to his family or group, he is usually ostracized if he persists. Consequently, his survival in this new way is hardly likely and very difficult if at all possible.

When the family or household makes the same decision, it is easier for them to survive any ostracism because the group has the potential of being selfsufficient. Furthermore, the members are a source of support, encouragement, and strength for one another. Consequently, Runyon may be right when in examining the principle of evangelizing the household in Acts he suggests that household evangelism means the sharing of

\section{"To thy friends" [Mark 5:19], SDA Bible} Commentary, 5:606. "Literally, 'to those of you,' that is to his own relatives." 
the gospel with a group of people who has some kind of relationship, whether family members, relatives, or associates. These people are in some common sphere of influence. ${ }^{1}$

\section{Selected old Testament Parallels}

A brief overview of the old Testament also reveals a tendency to save by households. Selected examples gives some credence to this statement.

At the time of the flood, Noah was saved with his family. When God called Abram to leave the Ur and to establish the covenant with him, he moved out with his family which included, at least, his wife, some servants, and his nephew Lot with his family. Similarly, when the angel was about to destroy Sodom, Lot was asked to get his family, including those who had left his domicile and had set up their own family and home. While the children of Israel were in Egypt, God saved and delivered them as a people group--as a household.

Summary

Strategy may be defined as the general approach that is used to achieve a particular goal. However, before attempting to identify the evangelistic strategy of the apostles, it proved helpful to identify their goal--

${ }^{1}$ Ronald D. Runyon, "Principles and Methods of Household Evangelism," Bibliotheca Sacra 142 (JanuaryMarch 1985): 65 . 
to make disciples of all nations. Next, it seemed beneficial to simply ask, How did they go about realizing their goal, in general terms?

They surrendered to the ministry of the Holy spirit in their lives. Under His direction they began to work in familiar territory where they were conversant with the people and their context. Then, gradually, they moved to less familiar territory, until eventually they entered the unknown fields of labor. They worked from the known to the unknown. The basic elements of this general strategy were:

1. They met the people where ever they were.

2. They preached, debated, discussed, witnessed, taught, and did personal and household Bible study.

3. Their illustrations and extra gospel support were taken from sources that were known to the particular audience.

4. They contextualized their message and method.

5. They reorganized leadership, administration, and personnel based on the demands of the changing situations.

6. New methods were allowed to evolve with each new situation.

7. They used the household-evangelism approach, consistently, as long as it worked.

8. They set up support systems for membership maintenance. 
9. They made Christians of people of Gentile nations without making them Jews.

Within these broad outlines, they successfully fulfilled their part of the gospel commission. At the same time, they left an adequate example for subsequent disciples to follow in order to complete the great commission.

\section{The Related Implication of Matt 10:34-37}

The events on which Luke has focussed in the book of Acts demonstrates that this method of household or group evangelism has been successful. Despite that, however, it may be advisable to assume a balanced approach which also caters to the individual's salvation be considered, since this is in harmony with the spirit of the Bible. Furthermore, we have no assurance that group evangelism will never fail, especially because of this evil age which is at times antagonistic to the claims of the gospel. This may have most likely been Jesus' concern when He said:

Think not that I am come to send peace on the earth: I came not to send peace but a sword.

I am come to set a man at variance against his father, and the daughter against her mother, and the daughter-in-law against her mother-in-law.

And a man's foes shall be those of his own household. ${ }^{1}$

'Matt 10:34-36. 
Here Jesus was addressing His disciples relative to the gospel and the worst possible impact. At the same time, He was trying to dispel the "mistaken opinion that some of his disciples apparently had, that the message they were to bear would result in nothing but peace." 1 He quoted from Micah the prophet.

What the prophet foresees as being the outcome of a corrupt and decaying social order, Jesus foresees as the result of $\mathrm{His}$ coming among men. It was not war he had in mind, but the strife and confusion which must inevitably follow the adoption of new and strange religious ideas.?

This is not to suggest that the salvation of the individual and the resulting disruption in the family was the standard evangelistic method then. Instead, it was the result of what would happen when one member of a household accepted the gospel and the others rejected it. Then there would be a violent separation of these closest of ties. The one who has accepted the gospel should be prepared to accept this kind of reaction and hold to his commitment. Love for parents or child or spouse should never be allowed to restrict in any detail one's total commitment to God when there is a conflict with both. In espousing this kind of stance Jesus said:

$5: 379$.

"Think not" [Matt.10:34], SDA Bible Commentary

'Edward Hastings, ed., The Speaker's Bible: The Gospel According to st. Matthew (Grand Rapids, Michigan: Baker Book House, 1971), 7(2):82. 
He that loveth father or mother more than me is not worthy of me: and he that loveth son or daughter more than me is not worthy of me. And he that taketh not his cross, and followeth after me is not worthy of me."

Under some circumstances household evangelism appears to be most appropriate. However, whenever this approach fails and an individual or a minority has indicated some interest or has decided to respond positively to the claims of the gospel, they should be encouraged. Even in the light of stern opposition and ostracism by others, the claims of the gospel take priority. It is not a matter of saving all or none, but whosoever wills. As Jesus indicated, the sword will have to be drawn if disciples are to be made of all nations in this evil, secular, and anti-Christ world.

\section{All Things to All Men (1 Cor 9:19-23}

Obedience to the gospel commission inevitably brings the evangelist in contact with people and social units of different cultural, social, economic, linguistic, ethnic, and religious backgrounds. In the process of faithfully making disciples of all nations, the apostles have demonstrated that the gospel and the method of presentation ought to be contextualized or adapted to a particular situation. At the same time the evangelist must ensure that the content, the spirit, and the intent

\footnotetext{
${ }^{1}$ Matt $10: 37,38$.
} 
of the gospel are faithfully maintained. This can be effectively done when the evangelist becomes uncompromisingly incarnational with the gospel and the particular situation in which he ministers.

The apostle Paul, on whose ministry most focus is placed in Acts, has set an appropriate example as he engaged both the Jewish and the Gentile worlds evangelistically. In summarizing this method of approach and explaining his apparent inconsistent conduct to the brethren of corinth, he said:

For though I be free from all men, yet have I made myself servant unto all, that I might gain the more.

And unto the Jews I became as a Jew, that I might gain the Jews; to them that are under the law, as under the law, that I might gain them that are under the law;

To them that are without law, as without law... that I might gain them that are without law.

To the weak became I as weak, that I might gain the weak: I am made all things to all men that I might by all means save some.

And this I do for the gospel's sake, that I might be partaker thereof with you. ${ }^{1}$

Paul had labored in Corinth for three years. ${ }^{2}$

Later on, while he was at Ephesus, he was made aware of some problems that were occurring in the corinthian church and with questions that were being raised about the apparent inconsistency with his ministry. Therefore, in an attempt to address these issues and for additional

\footnotetext{
${ }^{1} 1$ Cor $9: 19-22$.

${ }^{2}$ Acts $20: 31$.
} 
reasons, he wrote the epistle. ${ }^{1}$ In 1 Cor 1:1-6:20, he deals with life-style and behavior problems within the congregation. Next in 1 Cor 7:1-11:1, Paul replies to questions raised by the corinthian brethren.

According to 1 Cor 9:19, Paul states that though material gain was due him, he had chosen not to accept any. As a result, he was not obligated to any person. In spite of that freedom, he chose to make himself a slave for the sole purpose of saving as many persons as possible.

Like a slave, wishing to please his master,.. he was willing to comply with the habits, customs, and opinions of others as far as possible, without compromising principle. ${ }^{2}$

To the Jews or those under the law, Paul, because of his knowledge of their beliefs, customs, and practices, was willing to uncompromisingly participate in these, like the circumcision of Timothy (Acts 16:3) and the taking of a Jewish vow (Acts 18:18), in order to establish a cordial working relationship with the Jews. Patterson understands Paul's argument this way:

Paul did not suggest that he had been obedient to Jewish interpretations, but he did suggest that he had been obedient to the law of the old Testament, even to a degree not required in the

${ }^{1} 1$ cor $16: 5-8$.

"Made myself servant" [1 Cor 9:], SDA Bible Commentary (1980), 6:733. 
gospel itself, for the purpose of gaining those who were under the law.

When ministering to the Gentiles who did not

have the written Torah, Paul identified with them.

He mingled freely with them and disregarded all Jewish observances which he followed at other times; he also, as for instance at Athens, formulated his teaching so that it might make a stronger appeal to the Gentile mind.

He was and remained a Christian among the Gentiles even as he was and remained a Christian among the Jews.

As far as Paul was concerned, the salvation of people was vital. Consequently, he was willing to make whatever sacrifice or accommodation was necessary for the salvation of those with whom he came in contact. In discussing Paul's evangelistic flexibility, Gromack argues that

Paul accommodated his life-style and his methodology of presentation to the group he was trying to reach with the gospel. He did not alter his message or his morals. He was both firm and flexible at the same time. To reach the Jew, he chose to have Timothy, who was half Jew and half Greek, circumcised that missionary the team might have maximum effectiveness. ${ }^{3}$

Therefore, in fulfilling the gospel commission issued by his Master, Paul contextualized the medium in

1Paige Patterson, The Troubled Triumphant Church (Nashville: Thomas Nelson Publishers, 1983), 149-150.

${ }^{2}$ R. C. H. Lenski, The Interpretation of st. Paul's First and Second Epistle to the Corinthians (Columbus, Ohio: Walburg Press, 1946), 337.

${ }^{3}$ Robert G. Gromak, Called to Be Saints (Grand Rapids, Michigan: Baker Book House, 1977), 112-113. 
which the gospel was couched, the method used to communicate it, and adapted the evangelist life-style to the given situation. This made the gospel universal, supracultural, and appropriate to everyone everywhere. Should the current disciples follow this example, the ultimate fulfillment of the gospel commission would be greatly enhanced.

\section{Conclusion}

From this study thus far, it has been discovered that evangelism is the process of the proclamation of the gospel of Jesus Christ to everyone, everywhere. The sum total of all the activities or ministries of the church actually participate in this process. Therefore, it ought to involve every member of the church.

Though the word evangelism is not explicitly found in the Bible, the very'concept, content, and purpose of evangelism is identical with that of the gospel commission of Matt 28:18-20. The commission states, in essence, that the church is to make disciples of all people. This is a perpetual process in which disciples, as they are being made, make other disciples. They in turn make others, and the process continues.

The initial steps in fulfilling this evangelistic commission have been recorded by Luke in Acts of the Apostles. Here he highlights certain evangelistic events that show the various methods that were used to 
participate in the basic evangelistic strategy employed by the apostles. They moved from the known to the unknown. From Jerusalem with its Jews to the uttermost parts of the earth with its Gentiles. As the situation, circumstances, and people changed, so the method changed correspondingly. As they presented the gospel, the apostles used means, illustrations, and quotations from sources with which their audiences were conversant, and which they credited. Despite that, however, the content and the essence of the gospel was maintained with faithfulness.

It was quite evident, as the gospel reached the Gentiles, that particular emphasis was placed on the evangelization of households, groups, and the influential community personnel. This method, especially that of household evangelization, proved successful among these people who had little or no formal exposure to the special revealed will of God. It is important, however, that this should never be embraced as the only method for these or similar peoples. For where this group or cluster approach may fail, then the salvation of the individual must be encouraged. Jesus indicated that no family relationship can supersede the claims of the gospel on anyone.

It was also noted that the apostles identified and, in many instances, lived with the people for whom they labored. They contextualized their methods, the vehicle of the gospel, their administration, and, the 
personnel as the church grew and circumstances changed. Paul, on whom most of Acts focuses, was a worthy example as he adjusted to the existing context. Later on he explained his apparent inconsistent conduct by stating that he made himself all things to all men in order to save as many as possible.

The example of the apostles and the early church can be very instructive in assisting the development of an appropriate and relevant strategy of evangelism for current situations.

It is hoped that the foregoing discussion can form adequate lessons for assisting in the formulation of an evangelistic strategy for the churches of the south Caribbean Conference of Seventh-day Adventist in Trinidad, who will be working with Hindus in the interest of their being evangelized and saved in God's kingdom. 
CHAPTER III

TRINIDAD AND HINDUISM

\section{Introduction}

The fifteenth century is recognized historically as the age of European exploration and foreign expansion. It was during this era that the British companies with royal charters entered places in Asia, the Americas, and the caribbean. These companies set up colonies, and they showed but little regard for the interest and development of the local people. They were concerned with immediate riches. As a result they either explored for precious minerals or developed operations for providing raw material for the manufacturing industries in Europe. At the same time these colonized lands were used for marketing goods that were produced in Europe.

It was at this time, according to Brinsley Samaroo," that the British colonized India and exploited that nation in three forms. He observes that before colonization, India produced superior quality fabrics that

${ }^{1}$ Brinsley Samaroo, "The Early Years of East Indian Immigration," in Indian Arrival Day 30th May 1985, Maha Sabha Day 2nd May 1985, ed. Hardeo Singh and Motilal Gocool (Siparia, Trinidad: Sookhai's Printery, 1985), 21. 
were overtaking the European markets. However, with the advent of colonization, laws passed in Europe restricted the importation of oriental fabrics. These stipulations devastated the fabric industry, thereby making thousands of weavers redundant.

The agricultural sector was also adversely affected. Apart from areas that benefited them, the British neglected roads and drainage maintenance, and ignored needed drought-control procedures. As a result, during the monsoon periods, floods destroyed the land and crops; during the summer the land was parched. Such a situation frustrated the agricultural industry to the extent that the land had to be abandoned and the thousands of unemployed people had to seek employment in places like Fiji and Guyana.

In addition to all this, the Europeans imposed on the Indians a financial burden of maintaining the military and civil establishment that they (the British) set up on the failing Indian economy.

The resulting situation instilled resentment and dissatisfaction among the Indians. This erupted in frequent, violent revolts against the Europeans. After such revolts as the 1857 Lucknow revolt, hundreds of participants were deported to other European colonies to provide cheap labor. ${ }^{1}$ Some were sent to Trinidad and

\footnotetext{
I'bid.
} 
Guyana as indentured laborers. During that same period, the British sent approximately 30,000 Indians to Kenya to help build the railways that were designed to link Mobosa with Uganda.'

This unemployment and the prevailing economic situation forced some of the Indians to welcome emigrating to Trinidad. others were forced to emigrate or were deported as a form of punishment. This is substantially the reason why the colonization of other lands by the Europeans resulted in Hinduism being transplanted to places like Kenya, South Africa, Guyana, Fiji, and Trinidad.

This chapter deals with Trinidad and Hinduism. The chapter is divided into five main sections. The first briefly discusses Trinidad in historical perspective in order to show how East Indians and Hindus, in particular, came to be living in Trinidad. It also attempts to reveal how Hinduism survived in such an alien environment.

The second section provides a general examination of major Hindu beliefs and practices. Hinduism as practiced in Trinidad is very similar to that practiced in the provinces of the Ganges plain in India. However, with the advent of frequent travel between both

${ }^{1}$ Haren Sthalekar, "Development, Implementation, and Evaluation of an Evangelistic Approach for Grjarati Hindu Indians in Kenya" (D.Min. project report, Andrews University, 1981), 9-10. 
countries and the exportation of culture from India to Trinidad, deletions and weaknesses in the religion have been receiving considerable attention. Nevertheless, a close observation reveals that there are definite differences in terms of adaptation and variations that have been culturally and geographically conditioned. Attention is given to these specific peculiarities in the third section.

The fourth section attempts to make a comparison between the generally accepted major beliefs and practices on Hinduism and the corresponding fundamental beliefs of Seventh-day Adventists. This is an effort to highlight prevailing differences and similarities.

Finally, the fifth section is a general conclusion on the entire chapter with a bearing on the evangelization of Hindus in Trinidad.

\section{$\frac{\text { Historical Background of Hinduism }}{\text { in Trinidad }}$}

Trinidad in Historical Perspective Trinidad is the larger of the two islands of the twin-island Republic of Trinidad and Tobago. It lies ten and one-half degrees north latitude and sixty-one and onehalf degrees west longitude, and about six miles off the eastern coast of Venezuela. This island is 1,864 square miles of mostly gentle undulating landscape, interrupted by the mountains of the Northern Range, which sharply rise 
to 3,085 feet, the Central Range, and the southern Range. Three major swamp lands or lagoons are connected with the three longer rivers on the island. These are the caroni Swamp which lies on the northwest, the Nariva Swamp on the east, and the oropouche Lagoon on the southwest. These areas became the area of settlement for most of the East Indians. 1

Trinidad was discovered by Christopher Columbus on his third voyage in 1498. As a result, it was under spanish rule for three centuries. ${ }^{2}$ subsequently, it became the first British crown colony, after which it experienced a series of rulership changes among the Dutch, the French, and the British. ${ }^{3}$

originally, Trinidad was inhabited by Amerindian Indians--Caribs or Arawaks or both. ${ }^{4}$ Though there are people today who claim Amerindian ancestry, they are very few. The original inhabitants were decimated by the Spanish conquistadors whose interest was quick wealth. When the British colonized Trinidad and attempted to

\footnotetext{
${ }^{1}$ Arthur Niehoff and Juanita Niehoff, East Indians in the West Indies (Milwaukee, Wisconsin: Milwaukee Public Museum, 1960), 13.

${ }^{2} J a n$ Knippers Black, Howard I. Blutstein, Kathryn Therese Johnston, and David S. McMorris, Area Handbook for Trinidad and Tobago (Washington, D.C.: Government Printing Office, 1976), 1 .

$$
\begin{aligned}
& { }^{3} \text { Ibid., } 9 . \\
& { }^{4} \text { Ibid., } 14 .
\end{aligned}
$$
}


develop an agricultural base as a source for raw material, they introduced African slaves as a cheap source of labor. This met with a degree of success until 1838 when slavery was abolished. To fill the labor force vacuum that resulted, plantation owners tried importing Chinese, Portuguese, and free Negroes from America. This proved a futile effort. ${ }^{1}$ Finally, and with the most success, East Indian indentured laborers were introduced from the Asian sub-continent.

This last effort was successful for two basic reasons. In the first place, there was a desperate need in Trinidad for laborers. At the same time, India was experiencing a downturn in its economy, due to inconsiderate European colonization practices.

Emigration, therefore, became a welcomed phenomenon. ${ }^{2}$ The East Indians went to Fiji and Trinidad, among other places.

\section{The East Indians}

The East Indians, who emigrated to Trinidad, came from North Central India. This was in the region of the Ganges River plain. That area included the United

'Ibid., 15.

${ }^{2}$ Samaroo (in Singh and Gocool), 21-23. 
Provinces, the Central Provinces, the North West Provinces, and Bengal.'

In some years there were more people from such provinces as Punjab and Bengal, but in all years the proportion of people from the provinces of north, central India was from 8090 per cent. It is clear that the bulk of migrants came from Hindustan, the Ganges River Plain. Another indication that they were predominantly from this area is the spoken language that they brought to Trinidad. Today practically all East Indians who speak any Indian language (the majority), speak Hindi. In all public gatherings and all rituals in which an Indian language is used, it was Hindi. ${ }^{2}$

From these regions mentioned, a variety of methods, including some that were illegal, were used to recruit and contract laborers. ${ }^{3}$ They were taken mainly to Calcutta and Bombay to await the next available ship for Trinidad. They then sailed to Trinidad where they worked on prescribed estates under a contract that lasted for a minimum of five years. During that time they were restricted to the confines and regulations of the estate. At the termination of the contract, the indentured laborer could renew it and continue to work on the estate. He also had the option of settling on an available parcel of land and there establish his desired independence. Finally, he could return to India with all, Indies, 17 .

${ }^{1}$ Niehoff and Niehoff, East Indians in the West

Irbid.

${ }^{3}$ Ibid., 16 . 
in some cases, or part of his fare paid by the estate. Initially, the majority chose the last option. However, as the program became older, and with the passing of time, the percentage returning to India dwindled. That, in addition to the high birth rate among East Indians, contributed to the fast-growing Indian population in Trinidad. From 1946-1960 it increased by 4 percent. This was considered the highest population increase in the world. 1

The Indians who decided to remain eventually moved off the estates and settled predominantly within the environs of the oropouche Lagoon and the Caroni Swamp. ${ }^{2}$ These locations were ideally suited to the agricultural methods with which they were acquainted, especially in the production of swamp rice. Furthermore, there is the possibility that these areas might have borne some resemblance to the Ganges Plain. As the East Indians settled in these regions, they attempted to reestablish their original way of life.

they set up markets in precisely the same manner that their ancestors had established in Bihar and Uttar Pradesh; selling the same vegetables whose seeds and cuttings they brought from the East; giving to those market settlements the very names of the places from whence the immigrants had come. . . - They also introduced animals such as the water

\footnotetext{
${ }^{1}$ Yogendra K. Malik, East Indians in Trinidad: A study in Minority Politics (London: Oxford University Press, 1971), 6 .

${ }^{2} \mathrm{Niehoff}$ and Niehoff, 19.
} 
buffalo, new strains of poultry, cattle and goats. With these plants and animals they also introduced new methods in agriculture and farming, which had been developed in India over thousands of years.'

As a result, Trinidad has become a land of strong Indian communities. The majority of these people, though born in Trinidad, hold their "indianess" and the tradition of their ancestors in high esteem. This has become a positive base for the progress and persistence of Hinduism which is experiencing a resurgence of interest among the young and educated class on this island.

\section{Socio-cultural context}

Trinidad is an island of significant sociocultural and ethnic diversity. It is in such a setting that the East Indian has been able to persist as a distinct sub-culture, with peculiarly unique values, institutions, goals, system of authority, and cultural practices.

Kinship and family

The extended family, as it originally existed in India, did not survive with any notable significance in Trinidad. Such a phenomenon has been due to four principal factors. First, the system of recruiting indentured laborers was more concerned with the individual, for work, rather than the family. As a result 
not many families nor women originally emigrated. In addition, since it would have taken at least thirty-five years to develop a minimal extended family and there was an obvious shortage of women, it was not feasible to begin families even though there might have been the desire to do so soon after emigration.' second, the European nuclear-family model, to which everyone, including the recently freed slaves, aspired, did everything but encourage the survival of the extended family. Third, the advent of post-world war industrialization and better economic opportunities did not make the extended family a conveniently needed institution. ${ }^{2}$ Fourth, growing family conflict made the nuclear family a more peaceful mode of existence. 3

The few extended families that have persisted have been the result, usually, of two extreme necessities. The first has been in cases where a successful business venture existed that needed the services of everyone. At the same time the financial standing of each unit in these extended families have been enhanced. The other situation concerns those units comprised of unskilled and undereducated laborers, those who are at a great disadvantage

${ }^{1}$ Barton M. Schwartz, "Patterns of East Indian Family Organization in Trinidad," Caribbean studies 5, no. 1 (1965): 28 .

$$
\begin{aligned}
& { }^{2} \text { Ibid. } \\
& { }^{3} \text { Malik, } 28
\end{aligned}
$$


to compete successfully on the labor market. Therefore, they are engaged in seasonal work, the income from which has been used to supplement their joint agricultural

produce. Thus, mere survival necessitates their continuation in the extended family system.'

since the extended family did not survive on a large scale, a closely knit kinship group has emerged in its place in the different communities. Each group has been made up of "numerous real and supposed uncles, aunts, sisters, cousins, grandfathers and grandmothers." ${ }^{2}$ In this setting

The Indian child is brought up under a complex structure of kinship relations and family authority patterns. He is taught to obey his elders, pay them respect, and share manifold family responsibilities. ${ }^{3}$

In these kinship groups, the socialization process has taken place. It has been carried through life and, as a result, decisions are either a joint affair or the individual decision has to be within the harmonious confines of this existing social structure. It is to the family and to the kinship group that the average Indian gives primary allegiance as a socio-religious responsibility.

'Schwartz, "Patterns," 32-33.

2Malik, 27.

${ }^{3}$ Ibid. 
Culture

The East Indians who came to Trinidad found themselves culturally disadvantaged. The dominantly pervading culture that was significantly engulfing even the Negroes was European. These East Indians who had been poor, dispossessed, and disinherited were at the bottom of the socio-economic ladder. ${ }^{1}$ They were looked down upon and oppressed by the Europeans and were despised by the Negroes whom they had replaced on the estates. In addition, "their peculiar language, dress, food and religion . . . were neither understood nor accepted."2 Consequently, they developed an inferiority complex relative to their culture and life style. ${ }^{3}$

This situation was intensified by the activities of the Christian missionaries who worked among the Indians. They passed on to them Christian values that were culturally conditioned, while at the same time branding theirs as pagan and evil. Furthermore,

By becoming Christians they could undoubtedly raise their social status. It is believed by present-day Indians that at least up until the 1930 's there was a definite practical advantage in being a christian, particularly in getting a job. It was believed that until the $30^{\prime}$ 's a non-

\footnotetext{
${ }^{1}$ Niehoff and Niehoff, 60 .

"Kamla Ramlakhan, "Need for Cultural Awareness," in Indian Arrival Day 30th May 1985 - Maha Sabha Day 2nd June 1985, edited by Singh and Gocool, (Siparia, Trinidad: Sookhai's Printery, 1985) p. 39.

${ }^{3}$ Ibid., 40 .
} 
Christian Indian had very little chance of getting government job or a position as a foreman.

Therefore, the East Indian was discouraged from being whom he truly was.

From the 1930s some of the East Indian youth became educated and, as a result, were able to hold more prominent and respectable jobs. That contributed to selfpride, not only of the individual but also the kinship group and, vicariously, to Indians in general. They began looking to India for a sense of identity. At the same time, there were struggles for nationalism in India, and in these the East Indians in Trinidad participated vicariously. These circumstances coupled with the outstandingly influential leadership of Nehru and Gandhi ${ }^{2}$ gave the East Indians in Trinidad the identity boost and cultural exhilaration they had long needed.

simultaneously, cremation was officially permitted, ${ }^{3}$ and other favorable circumstances and events followed in rapid succession to give them significant encouragement.

A large number of Hindu and Muslim schools were opened, new and impressive mosques and temples were built, teaching arrangements for Hindi and Urdu were

${ }^{1}$ Niehoff and Niehoff, 149-150.

${ }^{2}$ Malik, 23.

${ }^{3} \mathrm{~J}$. C. Jha, "The Hindu Sacraments (Rites de passage) in Trinidad and Tobago," Caribbean Quarterly 22 , no. 1 (1976): 50 . 
made, strong efforts were made to revive cultural pride among Hindu and Muslim youths through the organization of Youth Clubs and study groups. Many wealthy Indian families maintained links with India either by visiting India or by getting religious and cultural literature from India. Indian 'movies' and Indian music draw large audiences of East Indians in Trinidad. Recently, Indian cultural troupes have started paying visits to Trinidad. Auditoriums and cinema houses where the Indian artists give their performances are very well patronized by East Indians from every section of the society and a large number of Indian ladies came dressed in saris-the traditional Indian dress. In Indian majority areas of Debe and Penal, music from Indian films is played over loud-speakers throughout the day-especially at weddings and festivals. Recently local Indian dancing troupes and orchestras have been organized. . . .'

This has lead to a more aggressive effort to develop and elevate East Indian culture and religion as an integral part of the Trinidad life style. So impressive and successful has been the impact of East Indian culture and its people, that Devali has been accorded national holiday status. ${ }^{2}$ In addition, the teachers in the majority of East Indian and Hindu schools are paid and trained by the government. The terraced cremation site at the western end of Mosquito creek in South Trinidad was built by the government. This facility is in constant use.

${ }^{1}$ Malik, 10 .

${ }^{2}$ See appendix $C$. 
Education

During the early years of the East Indian settlement in Trinidad, parents were involved substantially in family agriculture, which at times involved their children. This was due most likely to the absence of mechanization. The life goal of many East Indians, was to own a house and a parcel of land and be self-sustained and live relatively independent lives. Consequently, no one paid particular attention to the education of these East Indian children. ${ }^{1}$ The Presbyterian missionaries, under John Morton, recognized the situation as a problem and an opportunity. Therefore, they established twelve primary schools in South Trinidad for these educationally deprived, East Indian children. ${ }^{2}$ These schools assisted greatly in improving the social standing of the East Indians, while, at the same time, some of them did became Christians.

Because the Christians monopolized professional jobs, it was expedient for Hindus to be converted to Christianity in order to secure a job--even as a teacher in a government school. Those conversions, whether real or convenient, created friction in families and kinship

\footnotetext{
'Malik, 14 .

${ }^{2} \mathrm{Black}$ et al., 58 .
} 
groups. 1 As a result, a growing concern and agitation among Indians led to the establishment of the first Hindu\Muslim school in 1932. Twenty years later, six Hindu schools with East Indian teachers were organized and in operation. Now in 1989, about forty-one Hindu schools exist in Trinidad. ${ }^{2}$

Ethnically mixed schools are found, however, throughout the island since education is significantly government controlled and financed. As a result, Hindus can be found in every profession in Trinidad, even including the parliament and the senate.

\section{East Indians and Their Neighbors}

Since Trinidad is a multiracial society, the East Indians constantly interact with all ethnic groups. However, the Negroes form the one group with which all have the most contact. ${ }^{3}$ As a result, the Negroes have had the greatest impact on East Indian religion and culture.

Regrettably, constant economic and political competition and friction remain between Negroes and East Indians. Each looks down upon the other as being inferior

'Satnarayan Maharaj, "Hindu Schools--Their origin," in Indian Arrival Day - Maha Sabha Day, ed. Singh and Gocool, (Siparia: Sookhai's Printery, 1985), 15.

2Ibid. , 15-16.

${ }^{3}$ Niehoff and Niehoff, 64 . 
and refers to the other with derogatory names. ${ }^{1}$ This friction, which is covert, has been most emphatic and evident in the East Indian's strong disapproval of interracial marriages. Though some, particularly the Christians of East Indian descent, approve these marriages on principle, they are hesitant, nevertheless, to have their children participate in them. The Hindus, however, are strongly opposed and resistant to such marriages. 2

In terms of social and cultural involvement and interaction on a national level, the East Indians do participate. However, elite East Indians usually affiliate themselves with non-professional, exclusive clubs such as the Himalaya and the West Indian clubs. Those who attend the Rotary and Lions clubs find themselves at meetings that are dominated by local Whites or Negroes. ${ }^{3}$ In summarizing the social relationships, particularly between the Negroes and the Indians, Malik notes that:

Negroes and East Indians have been exclusive of each other's social structure--cliques, fraternal societies religious organizations, and home-visiting patterns. At the same time, at least on the surface, the two groups seem to tolerate each other, and are not engaged in open use of violence against each other. East Indians, being a minority, have been on the defensive. Negroes believe that within the next few generations the East Indians will lose

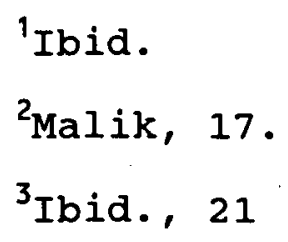


their ethnic identity and will become absorbed. East Indians are confident that they would not be lost in the intermixing of numerous West Indian racial groups.

Thus Hindus are very unhappy with Christian activities in their communities which manifest signs of proselytizing. As a result of this uneasy relationship, and exclusivism, the evangelization of the Hindus is a great challenge.

\section{Hindu sects in Trinidad}

The East Indians who came to Trinidad were of mainly two religions: The majority were Hindus, and the percentage was about the same as that in the Ganges Plains. The others were Muslims, and a minute number of Christians (about .6 percent).$^{2}$ Here particular attention is be placed on Hinduism, especially the four major sects. Contrary to Western Christianity, the Hindu religion is not an aspect of life, but life itself. Therefore, it affects and informs all the major issues of each person's life. As a result, the indentured laborers who emigrated to Trinidad brought with them ". . almost all the intellectual, meta-physical and ritualistic traditions of Uttar Pradesh and Bihar. "13

${ }^{1}$ Ibid., 24 .

${ }^{2} \mathrm{~J}$. C. Jha, "Indian Heritage in Trinidad (West Indies)," Eastern Anthropologist 27, no. 3 (JulySeptember, 1974): 214 .

${ }^{3}$ Ibid. , 215. 
As in India, different Trinidadian Hindu villages and communities show a preference for worshiping parti-cular deities. Beyond that, there are distinct Hindu sects with their peculiar identities. Of these, four major sects emerge in Trinidad. These include the Sanatan Dharma, the Arya Samaj, the Kabir Panth, and the Seunerinis (Seunarianies) or Siva Sarayanis.

\section{Sanatan Dharma}

The Sanatan Dharma initially existed as two independent organizations. They were the Sanatan Dharma Association and the Sanatan Dharma Board of Control. These were organized into one body, the Sanatan Dharma Maha Sabha, in 1952 by C. B. Mathura and A. B. Sahay, the then Indian High Commissioner to Trinidad. ${ }^{1}$ This sect has the largest number of adherents and is by far the most influential politically, economically, and socially. Being orthodox in their religious traditions, this organization is affiliated to the Sanatan Dharma Sabha of India. It is not surprising to find all four castes in this sect which is lead by the highest caste, the Brahmins.

$$
{ }^{1} \text { Malik, } 33 .
$$


". . Sanatan Dharma places great emphasis on the duties and obligation of a Grihast--the householder." 1 Because, in Trinidad, many do not progress beyond this one of the four stages in life, there has been need for numerous pujas to the different gods, performed by the pandits in the homes. ${ }^{2}$

\section{Arya Samaj}

The Arya Samaj

was started in 1875 by Swami Dayanand Sarasvati, whose object was to purify Hinduism and restore it to what he considered to be its pristine form. . . .

This Hindu sect did not originally emigrate to Trinidad; instead, missionaries from Guyana organized it here. The adherents advocate strict observance of the Vedas. They reject the caste system, idolatry, and the inferior status of women. They seem reformed in their thinking. However, as a result of internal friction and schism, there has been a loss of membership and influence, and very few of them remain in Trinidad today. ${ }^{4}$

${ }^{1}$ Particularly among Hindu males, especially among the high caste, there are fourstages in life: the student, the householder, the forestdweller or hermit, and the wanderer.

\section{Ibid.}

${ }^{3}$ L. S. S. O'Malley, Popular Hinduism (New York: Johnson Reprint Corporation, 1970), 226.

${ }^{4}$ Ibid., 32 . 


\section{Kabir Panth}

This Kabir Panth, which can also be classified as a reform sect in North India, was founded by the poet named Kabir during the fifteenth century. Principally, the adherents reject the teaching and practice of the caste system and advocate the worship of an internalized god. They are somewhat syncretistic in that they tend to blend specific elements of Hinduism and Islam, yet they regard themselves as Hindus. Because they are from the lower caste, their following and influence have not been significant.

Seunerinis (Seunarianies) or Siva Naryanis

The origination of the seunerinis can be traced to the nineteenth century. The followers subscribe to an anti-Brahman philosophy. They usually read from the prophets in their worship which is done without a pandit. Because of their supposed intemperate use of alcohol, and due to the fact that they are from the low caste, they are not very prominent.

Since the Sanatan Dharma Maha Sabha is the most orthodox and the largest of the Hindu sects in Trinidad, this study addresses itself mainly to this aspect of Hinduism. An effort is made to observe some of its basic teachings and practices. 


\section{Prominent Features of Hinduism}

Hinduism tends to be an all-inclusive and somewhat syncretistic religion. Its religious beliefs and practices are many, varied, and, at times, apparently conflicting. In addition, Hindus are not asked to subscribe to nor confess a system of beliefs since one is not converted to but is born into Hinduism. Notwithstanding, some basic beliefs and religious practices can clearly identify one as a Hindu, though these may appear in variant forms. Following, a brief study is made of selected beliefs and practices. This is by no means an exhaustive study since the limited scope of this project report cannot accommodate nor justify such a treatment of the subject.

\section{Major Hindu Scriptures}

Hindu scriptures are voluminous. They are many and varied, extensive and comprehensive. In keeping with the limitations of this project, only the most popular and most prominent ones are briefly examined.

\section{Primary Hindu scripture}

The Vedas

Apart from archaeological discovery, much of what is known about the early historical develop-ment of Hinduism has come from its sacred literature. These have been claimed as divine revelations that were transmitted 
by Brahman to the Rishis, the prophets, at creation. As religious traditions, they were transmitted orally from generation to generation. This was not done on a large scale but from teachers to students of the elite, priestly caste. Subsequently, these traditions were committed to writing when "the Sage Uyasadeva compiled all the Vedic Sastras in written form and were called the Vedas." 1 According to Gosvami:

The Vedas are mainly hymns, chants by priest in praise of the gods. These are: The $\mathrm{Rg}$ Veda . . . consist of 1,017 hymns arranged in ten books. Most of the verses are in praise of Agni, the god of fire and Indra, the god of rain and the heavens. The Yajur Veda contains instructions for performing sacrifices. The Sama Veda is "the Veda of Chants" and consist of 1,549 verses, many of which also appear in different context, within the $\mathrm{Rg}$ Veda. The Atharua Veda contains chants and rites, often for healing sickness."

This body of religious literature has been used principally by the upper caste, the Brahmins.

\section{Secondary Hindu Scriptures}

Apart from the Vedas, other sacred literature has been written by the Hindu saints in the course of history. For the most part, this consists of commentaries or explanations on the principles enunciated in the Vedas. Among this group of literature, which is more voluminous,

${ }^{1}$ Satavarupa dasa Gosvami, Readings in Vedic Literature (Los Angeles, California: Bhaktivedanta Book Trust, 1977), 4 .

$$
{ }^{2} \text { Ibid., 40-41. }
$$


- . there are four Braahmanas and the Aaranyakas which deal with the methods and the meanings of Yajyas . . . and several other religious and mystical topics. Then there are the four Upa-Vedas. They deal with the science of medicine and the treatment of diseases, the science of economics and state administration. The next set of books are the Vedangas. . . . They are six in number and deal with the science of phonetics grammar, linguistics prosody, rituals, astronomy and astrology, including mathematics. Then there are the Upanishads, Darshanas, the Shaastras, the Puraanas, the Raamaayan and the Mahaabhaarat.

The Upanishads

The Upanishads reflect different schools of thought since their origin was somewhat personal and subjective. They emanated from religious, mystical, philosophical, and sociological interaction between student and teacher that took place in remote seclusion. These were eventually written down. Because these texts evolved in a hermetical context, it is not surprising that

from time to time they criticize the performance of rituals as superfluous to the religious quest. Some texts extol the renunciation of society and the performance of austerities that in later Hinduism became increasingly important techniques for liberation. ${ }^{2}$

In order to reconcile the varying differences advocated by different schools and teachers, Hinduism takes the position that though

${ }^{1}$ D. N. Vidyarthi, What Every Hindu Must know st. Augustine, Trinidad: Texprint, 1988), 34.

${ }^{2}$ David R. Kinsley, Hinduism (Englewood Cliffs, New Jersey: Prentice Hall, 1982), 13. 
the Upanishads are somewhat diverse in their teachings, all agree that underlying reality is a spiritual essence called Brahman. The Upanishads involves realizing the fundamental identity of Brahman and Atman and realizing that one's essential self transcends individuality, limitation, decay and death. The realization of this truth wins the adept liberation or release (Moksha) from the shifting world of constant flux and endless cycle of rebirth (Samsara) which are perpetuated and determined by all one action (Karma).

Therefore, regardless of what any one particular Upanishad teaches, all, in general, revolve around and are informed by the quest for absolute reality and eternal release from samsara into moksha.

Two Epics

During the historical period between the last five centuries $B C$ and the first five centuries $A D$, the time of consolidation and permanent establishment of the Aryan/Indus civilization the two Epics emerged. These were portrayed in two sacred writings of the sacred literature, the Mahabharata and the Ramayana, written by the sages.

Both epics concern themselves with royal rivalries, perhaps reflecting the political turmoil during this period and reflecting in their rambling ways, a tension between a religion aimed at supporting and upholding the world order and one aimed at isolating a person society in order to achieve individual iberation.?

${ }^{1}$ Ibid.

${ }^{2}$ Ibid., 14 
The Ramayana

The Ramayana's hero is Rama who, with the help of Hanuman, rescues sita from the captivity of Ravana who was a demon king of Lanka. When Rama was installed as king of Ayodhya, a tragic situation was created because his wife sita had been captured. In spite of his genuine

- love for her and his desire to have her with him, Rama banished her, putting the social and national interest before his own personal desires.

According to Vidyarthi, the main lesson of the Ramayana, as is depicted through its main characters, is that external adorning, material and this-worldly possession, and accomplishments are not absolutely valuable. True value is an internal virtue that results from ethical, moral, and spiritual progress.' ${ }^{1}$ The

Mahabharata

The heroes of the Mahabharata are the Pandavas brothers. Arjuna, the chief warrior of them all, has to decide whether to leave the kingdom, avoid war with his cousins and escape from the world, or fight and thus share in maintaining the cosmic order. At the same time, his brothers and the god, Krishna, counsel him that it was not a case of either war and rule and ensure social order or

\footnotetext{
${ }^{1}$ vidyarthi, 42 .
} 
escape from the world, but both. This is realized through unselfish social service.

In short, Krishna expresses a central theme of Hinduism, namely, that each person has a double responsibility: (1) responsibility to maintain social order and (2) responsibility to seek individual liberation from Karma and Samsara.'

The fundamental lesson of the Mahabharata is

that evil may seem to triumph. However, such triumph is transient in the presence of good. Ultimately good will triumph. Therefore, it is important that every man be in touch with god if he is to truly succeed and be victorious.

Bhavagad Gita

TheBhavagad Gita is the most commom of all Hindu literature. It is discussed in more detail under "Canonization."

\section{Canonization of Hindu Scriptures}

The inclusive system by which Hindu scriptures evolved and developed facilitated the entrance of a wide variety of material. Some of these manifested seemingly conflicting differences. Despite that, there has been a process of authorization and authentication. This has provided the necessary checks and balances that allow for some consistency and the reconciling of the seemingly disharmonious differences.

\footnotetext{
${ }^{1}$ Kinsley, 34 .
} 
By virtue of its age and elevated prominence, and the unique position it occupies in terms of inspiration and instruction, the Vedas have been used as the calibrator for all other sacred writings. Notwithstanding, in an effort to justify the inherent authority and authenticity of the Vedas, it has been argued that

The Rg Veda, Yajer Veda, Sama Veda, Athawad Veda and Itihasas. . . are all breathed out by the absolute Truth. Just as one's breath comes easily, there arise from the supreme Brahman without any effort on His part. "According to Vedic tradition the Vedas are absolute and self- authoritative. They depend on nothing but themselves for explanation.

Therefore, as all scriptures that have been legitimized by the Vedas and accepted by Hinduism are examined, it has been advocated that

The Vedic scriptures comprise a harmonious whole with a harmonious conclusion. Consequently, we may accept as a bona fide writing any work that expands on Vedic siddhanta without changing its meaning, even if the work is not one of the original scriptures. However, to be genuine, these extensions of Vedic literature must strictly conform to the doctrines of the Veda, the Puranas, and the Vedanta-Sutia. ${ }^{2}$

This system allows for the inclusion of the diverse and copious quantity of literature that Hinduism now posses. This may be the reason why Pundits ignore contradiction and disharmony than religious philosophy.

\footnotetext{
${ }^{1}$ Gosvami, 3, 4 .

'Ibid., 1, 2 .
} 
The Bhagavad Gita

Hindu scripture is abundant and overwhelming. As a result, it is extremely difficult for anyone to assimilate or understand it so that he or she could effectively utilize all of it. It becomes a monumental challenge for the average mind. Therefore, the Bhagavad-gita emerges as the best document that summarizes the varied views and traditions of Hinduism in general. As Gasvomi puts it:

Where should we look for the Vedic siddharata? Is there any one work epitomizing and clarifying the different thematic strains, their relative positions and conclusions? clearly, such a compendium of the Vedas would have to be authoritative and acceptable to all school of thought. And clearly, of all works, Bhagavad-gita best meet these qualifications. For this reason alone the Gita has become the best known and most frequently translated of all Vedic writing.

The Bhagavad Gita, therefore, has become the most popular and readily available of all Hindu scripture. In support of its effectiveness, it has been observed that - . the Bhagavad Gita . . is a part of the Mahabharata. The Gita's solutions is philosophical, suggesting that true renunciation may be undertaken in the world while fulfilling one's social duty. Selfless action without desire for reward, action as an end in itself, is true renunciation for the Gita, and as such no tension need exist between one's dual obligation to support the world and to seek individual liberation. ${ }^{2}$

\footnotetext{
'Ibid., 39.

${ }^{2}$ Kinsley, 38 .
} 
Because of the apparent resolution of the tension between one's social responsibility and personal liberation in the Bhagavad Gita, it has been recognized as complete and sufficient. So "if one reads the Gita in the proper spirit, he can gain Vedic knowledge through the natural powers of Sabda." "1

of the many Hindu scriptures, the Vedas (Rg Vedas) is primary and most important. It authenticates and authorizes all other scriptures. The Vedas, nevertheless, is not a common book, since it is mostly used only by the Brahmins, the upper caste. Among the other scriptures, the Epics and, especially, the Bhagavad Gita are those which seem to touch the lives of most Hindus; they are the ones most commonly used by and on behalf of the average Hindu. Because the Bhagavad Gita is considered to be very consistent with the Vedas, it is respected as authoritative.

\section{Hindu Deities}

To the casual observer, Hinduism appears to embrace a confusing multiplicity of gods. However, a more precise investigation reveals more simplicity in the order and organization of its deities.

\footnotetext{
${ }^{1}$ Gosvami, 38 .
} 
Brahman

According to Hindu tradition, Brahman is the supreme being. He is neither transitory nor material but supreme reality and essence. He is the source and originator of everything. Putting it more explicitly:

Brahman, being the absolute, is one, invisible unchangeable, beyond action and inaction, beyond good and evil. But latent within Brahman as within a seed, is the power of life. When this power is manifested in the creation of the universe it takes the form of Maya the material world we perceive with our senses.

Hindu thinking seems to suggest that even this description does not do justice to Brahman because categories of this world lack the capacity to adequately reveal the reality of Brahman which transcends visible reality.

Younger and Younger state:

Brahman means roughly "the fullness," or "the ultimate." The concept is used in order to refer to the ultimate reality with out employing images from this world. Brahman is truly beyond this world, and any descriptions used to define the concept would falsify and limit it.?

At the same time, paradoxically, Brahman is believed to be existentially in this world as Atman. It transforms itself into everything in nature. Even the

${ }^{1}$ Henry R. Luce, ed. The World's Great Religions (New York: Time, 1957), 15.

${ }^{2}$ Paul Younger and Susanna olmmen Younger, Hinduism (Niles, Illinois: Argus Communications, 1978), 38 . 
soul of man is considered analogous with Brahman since everything originated from it.

\section{The Triad}

It has been advocated by some that Hinduism subscribe to a trinitarian teaching. However, this is quite different from the orthodox Christian concept of the trinity. Hinduism does not believe in three distinct persons in its deity, rather it supports three different manifestations. In order to be approachable and available, Brahman manifests himself in different forms. - - Brahman appears in the form of the god Brahma to create each universe, the form of Vishnu to sustain it, and the form of Shiva to be the eventual destroyer.

Vishnu

Though Hindus may have local family or community deities that they regularly worship, it should be pointed out that, in general, they become devotees of either Vishnu or Shiva, who have to do with the daily issues of life.

Those who worship Vishnu sees him as a god of love. For a vishnuite salvation is usually won by bhakti, a loving devotion to god as preserver. . . . Vishnu took on physical form--became incarnate to overcome evil.

It is one of the forms of his incarnation or avatars of which there have already been nine chief ones, that is usually worshiped. of the nine, the two most important are Rama and

$$
{ }^{1} \text { Luce, } 15 \text {. }
$$


Krishna. A tenth, Kalki is scheduled to appear in 425,000 years.

Vishnu, however, is usually depicted as a fourhanded god who carries a flower or lotus, a mace, and a conch shell. He is seen sitting on Ananta, his multiheaded serpent couch, with Lakshmi his wife. Brahma the creator, emanates from a lotus that come from the navel of Vishnu. As is necessary, Vishnu incarnates himself as a fish or turtle to struggle with demons. Then, he may become as a man-lion, a boar, and a child-dwarf, who thwarts a king's activity against the gods. He may also manifest himself as Rama with his wife Sita, who is an incarnation of Lakshmi, the wife of vishnu. Finally, he may appear as Krishna with his helper Hanuman.

Brahma

Brahma is regularly portrayed as a four-headed god seated in a flower or lotus. He also

- - holds sacrificial implements, prayer beads and a manuscript, presides from the mythical Mount Meru, where he lives with his pea-cock riding, wife, Sarasvati, the goddess of creative art. ${ }^{2}$

Shiva

Shiva is represented as a four-handed god with snakes around his arms and neck. He may be depicted riding a cow; with his wife Parvati; or dancing gracefully

\footnotetext{
1'Ibid., 16.

'Ibid., 21.
} 
on the back of a sword, holding a dwarf; or even sitting meditatively with the Ganges river emanating from his head.

Shiva, the destroyer, has a wife who manifests herself principally in four forms. These are the gracefully calm ladylike Parvati and Uma, the gruesome blood thirsty Kali, or the fierce Durga.

\section{Ashvins}

Some other deities, the Ashvins are the physicians to the gods. These include Ushas, the dawn goddess; Surya, the sun god; Agni, the god of fire; Indra, the thousand-eye god of the firmament; Chandra, the moon god; Vayu, the wind god; and Maruts, who controls the storm clouds and uses the thunderbolts as his weapons.

\section{Deities of the Lower order}

There are also other gods of a lower level. Some of these are Kubera, the god of wealth; Manu, an ancestor of the human race who survived a flood like Noah; and Soma, the god who is the intoxicating juice from the sacred soma plant. As these gods vary, so do the types of worship ascribed to them. ${ }^{1}$ However, each is most likely to bear some relationship or attachment to vishnu or shiva.

\footnotetext{
${ }^{1}$ Ibid.
} 
"Religious" Beliefs and Practices

\section{Creation}

Hinduism espouses an eternally cyclical creation process. This implies that there was never a time when there was never a creation and there will never be a time when there will be no creation.' In the creation process, Vishnu is depicted as lying on his multi-headed serpent couch on the inter-creation water. This time can be considered as the momentous option for another creation. Then out of the navel of Vishnu emerges a lotus, and out of the flower at the end issues Brahma, the creator. ${ }^{2}$ Three basic elements that Brahma uses and which are essential for creation are spirit, time, and matter. These are in or a part of Vishnu who is eternal. That is why it has been stated that

None of the gods created the world out of nothing. Brahma is often said to be a 'secondary' creator, creating 'new' worlds or reorganizing already existing eternal unitary matter. Being the eternal, matter is always the same yet different, and creation is linked to a potter taking a lump of clay from which he fashions many different shapes, all of them remaining, basically mere clay. ${ }^{3}$

\footnotetext{
${ }^{1}$ Vidyarthi, 153

${ }^{2}$ Luce, 21 .

${ }^{3}$ [East Indian Cultural Promotions] Swaagtam (An Annual Divali Publication), October 1987 , (N. p. By the Author, ) p. 31 .
} 
Brahma, through a series of evolutionary progressive activities, creates and populates the heaven, the atmosphere, and the earth.

According to Vidyarthi, the actual creation process is in four stages. The first is the sarga, during which time the subtle elements are formed. These are real, yet invisible. The second is the pratisaga, when the planets, sun, and aquatic life are created. Then, the third is the Shrishti, when plants and animals are brought into being. Finally, during the forth stage, "different people of different races were formed due to climatic and geographical variations on earth." 1

Whatever is seen in creation is not absolutely real but illusionary. Vishnu, then, preserves the creation through a number of eons comprising over four billion years. At the end of that time, Shiva enters the picture and destroys the creation which is absorbed by vishnu. The universe remains in a state of non-creation or probably more appropriately, inter-creation for just over another four billion years. This cycle actually takes "Two Thousand Mahaa-Yugas, or Eight billion six hundred and forty million years. "2

After this cycle the momentous option for creation reappears and the creation process is carried out

\footnotetext{
'Vidyarthi, 154.

${ }^{2}$ Ibid.
} 
again. This order of creation, preservation, and destruction keeps on being repeated in an eternally cyclical sequence.

The Doctrine of Man

Man was created perfect and pure, since he originated from Brahman the divine. He is a rational being with a soul which is unchangeable and unaffected by time, space, and circumstances. He also possesses a mind which has reason, will, and emotion. Man has a body which is unreal and subject to change, death, and destruction. Nevertheless, it is a necessary temporary housing for the soul. While the body is made up of water, fire, earth, air, and ether, the soul, being divine, was never made. It is

'Aatman' or the Divine spark in all beings. The 'Aatman' is self-existent, self-conscious and immortal. It is by the force of this 'Aatman' of inner-self (= Life Energy) that the body is vivified and the senses, mind, intellect, and the ego become activated and their functions become conscious mental processes. 1

The body is divided into three sections. There is the physical or gross body which is visible. Within that, there is the subtle or astral body, comprising the mind and component parts. Then there is the causal body which is like a thin veil separating the soul from the rest of the body.

${ }^{1}$ vidyarthi, 138 
Seventeen elements form the subtle body. They are the mind, the intellect, five vital breaths, five organs of action, and five organs of knowledge.'

It seems as though the subtle body is extremely important, especially relative to reincarnation. One of the vital functions of the subtle body is described thus:

The subtle body serves as the repository for the moral consequences, until they have their effect in the individual's rebirth. The direct moral consequences determines the kind of physical body to be taken at rebirth and the environmental conditions in which the individual will live.?

At death, the subtle body and the soul leaves the physical body which will be destroyed, preferably by fire. The subtle body remains dormant while it awaits the appropriate body it should enter based on the laws of Karma. Then this new person lives and eventually dies, and the process continues until moksha takes place where the person is lost into the blissfulness of Brahman. Therefore, no person is absolutely new and unique, since some aspect of him or her existed before in some form, whether higher or lower on the social scale. Each person and every creature is merely a reincarnation and in the process of samsara.

${ }^{1}$ Kenneth W. Morgan, ed., The Religion of The Hindus (New York: Ronald Press Company, 1953), 123.

'2 Ibid. , 124 . 


\section{Hindu Social orders}

Hinduism has been saddled with a stratified and hierarchical social order called the caste system. Though it seems to demonstrate inequality and differences in the value of men, Hinduism plainly teaches that all men are equal. The apparent conflict and inconsistency is reconciled by the doctrine of man and the laws of karma. Therefore, it has been stated that

all men are the composite of the same elements, the same mind stuff and the same Divine Essence, and are endowed with the same uniform moral qualities and potential.'

On this premise, all men are undeniably equal. However, the apparent differences are based on the fact that each person's present standing is the result of the life previously lived, since it has been established that

The philosophical ideas underlying the caste system are Karma, the moral law of cause and effect according to which a person reaps what he or she sows, and samsara, rebirth according to the nature of a person's karma.

Karma is the belief espoused by Hinduism that the life an individual lives now was determined by the quality of life he or she lived prior to reincarnation. In the moral law of cause and effect, one reaps in the present life what he sowed in the previous life.

\footnotetext{
'vidyarthi, 129

${ }^{2}$ Kinsley, 6 .
} 
This philosophy and the practice of dharma are responsible for the perpetuation of the caste system which is very repulsive to the Western mind. To the Hindu, it has nothing to do with oppression, but with the maintenance of cosmic order until the cosmos is destroyed. Each caste has a responsibility or a place to hold in the system of cosmic ordering, and to refuse is to contribute to chaos and hostility of the universe, which threatens all existence. As all men faithfully perform their designated dharma, there will be a peaceful and habitable environment where prosperity and success can be realized. At the same time, each individual can eventually reach the upper caste and subsequently experience moksha.

This moksha is the goal of the practicing Hindu-to be released from the law of karma and the samsara with its cycles of births and deaths. One, therefore, becomes lost in oneness with Brahman. The person ceases to be, for only Brahman is.

The caste system is a vital part of the Hindu religious system, though today it is illegal in India. This system is complex and not just divided into four social orders called castes, as is commonly stated. For there are subsystems within castes, some of which even overlap. In an attempt to account for this complexity, Kinsley suggests:

In essence, however, it is a social systemm that is composed of closed, endogamous groups, 
most of which perform a traditional occupation and all of which are ranked in a hierarchical order. The system as it exist in Hinduism today seems to be the result of a historical blending of two social systems, the Varna system which dominate vedic religion and the traditional Law Books, and the jati system, which is only vaguely described in Hindu literature but, which dominates Hinduism at the village level.'

The author further states that there are over

two thousand jati in India today who engage in different occupations. ${ }^{2}$ Nevertheless, occupation can never adequately define nor identify a jati since the classification varies from place to place. A better identity is that - . a jatis is geographically and linguistically limited and in most cases has the characteristics of a large kin group with distinctive customs, dress, diet and behavior. A jatis is self-governing, being responsible for the behavior of its own members, and only mingles with other castes in carefully circumscribed ways. ${ }^{3}$

Therefore, within one caste there may be several jatis each ranking itself higher than the other, especially if they are engaged in similar occupations.

The vanas system consists of four listed social groups or castes. There is a fifth that is not even mentioned at times because of its lowliness. The listed or classified four social groups

\footnotetext{
'Ibid., 122.

${ }^{2}$ Ibid., 124 .

${ }^{3}$ Ibid.
} 
In vedic conception, . . . is analogous to the human body, or the body of isvara (Bhagavan). Accordingly, the Brahmans are the head, the ksastriyas the arms, the vaisyas the waist, and the sudras the legs. In the social body, as in any other body, all parts are important, and no one neglects any part.

The Brahmins are the priests and scholars. This is the most elevated caste. Next, in social status, are the Kshastriyas, comprising of the warriors and rulers. Immediately beneath are the Vaishyas. Those of this caste are engaged in commerce and trade. The sudras are responsible for serving and supporting the upper groups. Finally, there are the untouchables, those which are unclassified because the members are considered rejects and pollutants to the others.

This above-mentioned classification has been imposed upon the numerous closed jatis, thereby stratifying their social ranking. This

gives the village jatis system a certain common pattern throughout India. The Verna model of society is well known throughout India, and jatis typically will identify themselves with one or another of four Varnas or be classed in a particular varna by other jatis. This identification has to do far more with prestige and relative rank than with actual occupation or social function. It is quite possible, for example, to find agricultural Hindus belonging to every one of four vanas.

$$
\begin{aligned}
& { }^{1} \text { Gosvami, } 67 . \\
& { }^{2} \text { Kinsley, } 125 .
\end{aligned}
$$


Although the caste system may appear sociologically hostile and even oppressive to some, it is an essential part of the basic fabric of Hinduism. Consequently, even though legislation in India may rule the caste system illegal, the pratice still persists to some extent. The caste system is indispensable to many staunch Hindus, since it is vital to the maintenance of the cosmic order necessary for the survival of humanity and the subsequent realization of moksha.

\section{Hindu Spiritual orders}

The Hindu, especially the higher caste male, in his journey through life between birth and death is expected to occupy the four spiritual orders or ashramas. These are the brahmacharya, the grihastha, the vanaprastha, and the sannyasa, correspondingly, the student, the house-holder, the forest dweller, and the wanderer.

The first two stages, those of the student and the householder involve obligation to society. The individual is supposed to study the sacred scriptures and learn sacred rites and uphold the world and to marry, procreate and serve society by means of his caste dharma. The last two stages, those of the forest dweller and wandering world renouncer, on the other hand aim at enabling man to realize his eternal destiny, moksha. '

This allows the Hindu in the process of life to fulfill his full responsibility of contributing to cosmic

$$
\text { 'Ibid., } 89 .
$$


order and securing his eternal release or moksha. As a result, the tension between the extrinsic responsibilities and his intrinsic desires are reconciled.

\section{Worship in Hinduism}

\section{Religious Leaders}

Before discussing actual forms of worship in Hinduism, it may by appropriate here to list and briefly examine the activities of those who participate in worship services and religious ceremonies. These include the priests, gurus, astrologers, pandits, sadhus, swami, sammyasin, yogi, and naus.

Priests

Normally, a temple is under the jurisdiction of a chief priest. He usually has many assistants who carry out the routines of the temple--maintaining the sacred fires, ceremonial sprinkling, and the serving of food. Those who are scholarly are involved in instructing. Some priests are available for hire to do pilgrimages. The domestic priests serve at family and private ceremonies and worship services. Where the families can afford it, these priests visit the home daily to do the worship. If a family is unable to afford the daily services of the priest, they hire him for special occasions only and the 
devotees worship their deities at the home of the priest. 1 These domestic priests never serve at the temples.

Gurus

Gurus are private spiritual directors and teachers of younger students who desire to be spiritual leaders. Such men are respected for their spiritual insights and the knowledge they acquired as they progressed from student to guru.

Astrologers

The astrologer counsels the families and the individuals so that in their undertakings and activities they can avert misfortune and experience success and prosperity. At times pandits assume this role.

Pandits/Pundits

A pandit is a virtuous or learned person with discriminating ability. He functions in one or more of the roles listed here.

Sadhus

Sadhus are virtuous holy men who have renounced all attachments to this world and its possessions. They roam freely, live a highly devotional life, and are friendly and helpful to every one.

$$
{ }^{1} \text { Morgan, } 158 .
$$


Swami

Swami are men who belong to sacred orders and have taken vows of poverty, chastity, and obedience, and, consequently, have experienced substantial spiritual growth and insights.

Sannyasin

Men who assume specified ascetic disciplines in order to experience moksha are called sannyasins.

Yogi

Yogi are those who have chosen to follow particular yogic disciplines of physical and mental control in order to advance spiritually.

Nau

The nau assists in making the altar, securing the needed articles, and serving the presiding priests at the pujas.

Worship Services and Ceremonies

For the Hindus, worship is not necessarily theoretically detached and liturgically structured as that practiced by some Christians. Neither is it restricted to a particular place at a particular time on a particular day of each week. Rather, worship for the Hindus is seen as a daily occurrence conducted three times a day, mostly 
by the community pundit or women who have the privilege of being at her home.

In Hinduism, worship is a very private activity. Even when the ceremony is a public event, the participation is strictly personal since each person has his own dharma. Morgan has emphasized that

Communal and congregational worship are foreign to the fundamental idea of worship and the orthodox Hindu looks upon both as poses and artificial elaborations.

For this reason the vast majority of worship services and religious activities take place in the home and may be initiated by different members of the family. Though there are communal devotions at the temple, the community is hardly ever there as a corporate body on those occasions.

Worship services are mostly comprised of chanting, reading, repeating particular prayers, meditation, and the offering up of various sacrifices. Worship services, when sponsored by a pundit for the entire community, or when conducted for the rich and socially elevated may be costly and elaborate. Otherwise, they may be simple and conducted at the home for the household. Regardless of which is done, the primary goal is for the maintenance of the cosmic order so that other desires can materialize.

\footnotetext{
'Ibid., 155.
} 
Since different manifestations of god are venerated above others in different places, then from home to home and from community to community there are in the order and content of worship variations, and many differences are naturally expected.

The worship services and religious activities of the Hindus are better understood and appreciated when they are classified. There are general rituals, which is what we have discussed thus far. But there are also pujas; these may be termed prayer meetings and they may be conducted at the homes or at the temples. Samskarus, the rite of passage, is another. In addition to these, there are pilgrimages and, finally, festivals of the Hindu yearly calendar.

Pujas

Pujas run the entire range from the very simple to the complex and elaborate. They are mostly conducted at the homes, though infrequently some are preformed in the temples. A puja is conducted for a specific purpose and in honor of a particular deity or manifestation. In this operation, the deity which is in the form of an image or symbol is treated as an especially official guest with the attending courtesies, favors, and protocol. According to Vidyarthi, these are performed through a ceremony of sixteen stages. 
1. Dhyaan: Focusing the mind directly on the deity.

2. Aavaahan: Invoking and welcoming the deity for the purpose of being worshiped.

3. Aasan: The enthroning of the deity.

4. Paadya: Offering of water for and washing the deity's feet as an act of humility.

5. Arghya: Offering a mixture of water, saffron, and sandalwood powder for washing the deity's head. (The diety is the form of an image or symbol, either carved or painted.)

6. Aachmanya: Offering of water as a thirst quencher.

7. Snaan: Offering of water from the Ganges for the deity's bath.

8. Vastra-aabhooshan: Offering of ornaments and clothes to the deity.

9. Madhuparka: Offering a blend of milk, sugar, ghee, and curd which, when sanctified, eradicates sins.

10. Yagyopaveet: The putting on of the sacred thread.

11. Pushpa: Offering beautiful, fresh, natural flowers.

12. Deep: The waving of the lighted lamp before the deity, the originator of all light. 
13. Naivedya: Offering of selected foods and fruits to the deity.

14. Tambool: Offering of betel leaves to the deity.

15. Aachaman: The sprinkling of water which consecrates the devotee for the puja.

16. Aarti: The offering of heartfelt love and devotion to the deity. This is done by lighting a deyaa or camphor and with flowers and some water waving them five times before the deity in a circular motion while the devotee is praying.'

Hindus perform pujas for a number of reasons. For example, a puja may be done in order to experience spiritual growth and cleansing. It may be performed to appease or placate a particular deity in anticipation of a gift of favor. It may be done as an act of thanksgiving or appreciation for the receipt of some benefit.

Though pujas may be performed as often as a devotee desires and to whichever deity he or she chooses, some pujas are performed to particular deities more frequently than others, and on specified days. In addition, designated color flags are hoisted on bamboo poles commemorating the deity and the puja.

\footnotetext{
${ }^{1}$ Vidyarthi, 95-97.
} 
Some examples include:

Puja

Hanooman

Surya Naaraayan

Ganesh

Govardhan

Saraswati

Lakshmi

Blue

Durgaa

Shiva
Day

Color Flag

Tuesday and Saturday Red

Sunday

White or Red

Thursday

White, Yellow

or Green

Thursday

unspecified

Thursday and sunday white

Friday

Yellow or

Saturday and Tuesday Yellow or Red Any day

White or Tangerine ${ }^{1}$

Celebrations of Samskarus

To the Hindus, the Samskarus are like sacraments, though they are rites-of-passage celebrations. Sixteen of these identify significant stations in the entire life cycle. These extend from conception to posthumous rituals. Three are performed from conception through the prenatal period. Six are done at different times during childhood, and an additional two relate to education. When maturity is considered to have been reached, another two are performed. Finally three are done during the final years of life, at retirement, at renunciation, and at death.

\footnotetext{
${ }^{1}$ Ibid., 105, 108, 109.
} 
Pilgrimages

Pilgrimages are an integral part of Hinduism.

Like other religious activities, pilgrimages are performed for a number of reasons. These may include

the completion of vows, for the appeasing of the deity in times of misfortunes, to gain prosperity and good fortune, and as simple acts of devotion to the Lord. ${ }^{1}$

These may be undertaken to any of a number of designated sites in India. A site is qualified by the fact that it may be the source of a sacred river or the river itself, where two of these rivers meet each other or meet the sea. ${ }^{2}$ It may be a mountain or other geographical place that has been declared sacred because of its association with a particular sage or the occurance of some divine event.

The type of ritual performed at these sites and the designated times are determined by the deity being worshiped, the particular site, the social status of the pilgrim, and the attending pandit. However, when these places cannot be reached, substitutionary places may be hallowed so that all who desire to perform a pilgrimage may be able to do so.

$$
\begin{aligned}
& { }^{1} \text { Morgan, 188-189. } \\
& { }^{2} \text { Ibid., } 190
\end{aligned}
$$


Festivals

Festivals which Hindus celebrate are situated in the Hindu calendar, based on the agricultural cycle, the solar cycles, the lunar cycles, or in honor of specific deities. Those most frequently celebrated are the following:

Holi (phagwah) is celebrated in the month of March to honor the ushering in of spring. This is a relaxing and enjoyable festival where reddish-colored or perfumed water is freely thrown on one another regardless of rank or class.

Ram Naomi celebrates the birth of Lord Krishna. Reading from the Gita is highlighted during this festival. During the month of February, Shiva Ratri is celebrated in honor of the awaking of Shiva. The devotees attempt to follow a highly devotional and spiritual lifestyle during this celebration.

Devali commemorates the victorious return of Lord Rama to his palace after his exile and his defeat of Ravana, the demon king of Lanka. This festival is also celebrated in honor of Lakshmi the goddess of light, prosperity, and cleanliness.

During October, when the celebration of this festival occurs, homes are cleaned thoroughiy. Deeyas (small clay dishes about two inches in diameter and onehalf to one inch deep) are filled with ghee or coconut oil 
with a cotton wick placed in the center. These are lighted as a candle to decorate both private and public premises. Hindus are very benevolent, especially on the day of the celebration. The lighting of the dias signifies the triumph of light, goodness, and truth over darkness, evil, and error.

The festivals in honor of the goddesses Durga, Lakshmi, and Saraswati Nav-ratab are conducted for nine days and nights. These festivals are, in many cases, community events. The frequency with which they occur and the quality of the festival is strongly influenced by the socio-economic standing of those concerned and the prevailing strength of the practice of Hinduism. These festivals, though they may appear to be social and festive occasions, are to the Hindus spiritual activities that are performed since they influence the existing cosmic order.

\section{Dharma}

Hinduism does not have a systematization of a set of doctrines that adherents are required to learn, know, or be able to share with others, relative to their salvation. Instead, Hinduism is practical and involves all of life's activities. One's basic responsibility is to fulfill one's Dharma which is first social and then personal. This is what informs whatever one does and how one lives. In light of the fact that it is believed that the material world is in chaos, every Hindu is called upon 
to perform his/her assigned dharma. This is in order to maintain a degree of stability in which one can survive until one escapes this world and experiences moksha. As Younger and Younger put it:

Dhaarma, then, is the order which gives structure and purpose to the universe. An individual's relationship to this order is understood as his or her dharma or duty. The cosmos, society and the individual are all guided by the principle of dharma. What keeps everything in its place and harmonizes and balances the many forces which make up the cosmos is the order called dharma.

The importance of the individual's

responsibility, participation, and survival is further emphasized by Kinsley in his book Hinduism. He states that

the Hindu scriptures on dharma known as the Law Books stress the importance in Hinduism of maintaining cosmic and social order. A basic assumption of the Law Books is that individual well-being and good prosperity can occur only when society and the cosmos as a whole, are well ordered. A person's first obligation is to others, to social groups such as family, caste, religion and kingdom. Another underlying assumption of these works is that disorder of various kinds is a constant threat to human existence. A human is called upon to strive steadfastly to create and maintain a habitable world within which one may not only survive, but prosper and to some extent even transcend one's physical limitation by creating an ideal environment on earth. ${ }^{2}$

Therefore, a Hindu cannot live unto himself or

herself nor for himself or herself. Personal success and well-being can only be realized when the individual

\footnotetext{
${ }^{1}$ Younger and Younger, 37 .

${ }^{2}$ Kinsley , 83 .
} 
deliberately participates in ensuring the well-being of everyone and everything around him/her. That is why there is no choice between personal salvation or social and environmental responsibility. They are inseparably bound and should be seen as two aspects of one unit.

\section{Salvation in Hinduism}

For Hinduism, salvation is not individual

deliverance from this world into a realm of celestial bliss. Instead, it is tantamount to nonexistence. It is escaping this chaotic world and samsara and entering into a oneness with Brahman. This also suggests participation in or being lost in Brahman. Though all of life's activities, directly or indirectly, participate in ultimate release or salvation, they can be classified under one of three yogas. Mental and physical disciplines are present, but neither is the end result nor the main concern of these yogas. Instead, yogas are exclusively religious and spiritual disciplines and relate directly to salvation or moksha as far as Hinduism is concerned. As Younger and Younger suggest:

- . in India the word yoga has a wider variety of meanings and usually refers to rather specific discipline of the yoga sutra text or to the different parts a religious person may choose in his or her quest for liberation.'

\footnotetext{
${ }^{1}$ Younger and Younger, 42 .
} 
It should be noted that it is important that each Hindu should find his or her particular yoga if he or she is to realize salvation. For the

Bhagavad Gita teaches that there are a number of different yogas, or ways of harnessing the world, and that a path of search for salvation which each individual undertakes will involve the discovery of the yoga most appropriate to that individual.'

The first type of yoga is very intellectual and academic and is called the Ajuna yoga. A manifestation or practice of this way is done, for example, by

carefully following the Upanishads or Shankara when they teach that the ... only true knowledge is to know that the self, or consciousness, is really a part of the highest self, Brahman/Atman. To know Brahman in this sense is not to know about it but to have gained the mystical knowledge which makes an individual one with Brahman.'

\section{Next, there is Karma Yoga which}

would be a discipline similar to that which Ajuna developed as he headed into battle--a yoga in which a person acts according to his or her normal dharma; but with detachment rather than passion and with an understanding that the action $\frac{i s}{3}$ in perfect harmony with the soul of the universe.

Therefore, what is emphasized here is that

social responsibility that is selfless is an essential

path to salvation. So it is not always necessary for one to become a wanderer or world renouncer in order to ultimately experience moksha.

\footnotetext{
I'Ibid., 43 .

${ }^{2}$ Ibid.

${ }^{3}$ Ibid.
} 
Finally, there is bhakti yoga which is a more devotive path. It has been stated that

A bhakti yoga would be one of many forms of devotion in which, through ritual and devotion to a chosen deity, a person becomes one with the Lord and through him, with the highest Brahman.'

This makes it possible for those of every caste including the untouchables to eventually, after a series of elevated births, deaths, and rebirths in the process of samsara, experience release into moksha.

\section{Peculiarities of Trinidad's Hinduism as Compared with India's Hinduism}

With the increasing prominence of East Indian nationalism under the dynamic leadership of Nehru and Ghandi, Trinidad East Indians have developed greater interest in India and the things thereof. ${ }^{2}$ As one travels along the streets in central and south Trinidad, the presence of Hindu temples in certain communities and upraised flags in several homes is a common sight. Though Hinduism has been in Trinidad over 150 years and has been under the constant influence of Christianity and the prevailing social forces, it has substantially maintained its peculiarity. For after studying Hinduism with its religious practices and ceremonies in Trinidad, Jah has noted in summary that

\footnotetext{
${ }^{1}$ Ibid.

${ }^{2} \mathrm{Malik}, 23$.
} 
Indian heritage in Trinidad seem to have been largely retained and some facets of Indian culture which have been swept away by the flood of Westernization or modernization are being revived. Some festivals are now a part of the Trinidad way of life ....

With respect to the sacraments of the Samskare, for example, it has been observed that the religious rituals have been shortened and the social aspect emphasized. However, when viewed as a whole, it has been noted that the important elements of the sacraments have persisted. ${ }^{2}$

Hindu peculiarities in Trinidad, though not radically different, are significant enough to be noted. The cow, for example, is not afforded the same elevated sacred standing as it is in India. Though a number of Hindus, especially in the rural areas, keep cows, they are for providing diary products rather than for religious ceremonies. ${ }^{3}$

Though strict vegetarianism among Hindus in Trinidad is a rarity, as a general rule they do not serve meat at their ceremonies and festivals. However, the prevailing attitude towards the eating of chicken and eggs

'Jha, "Indian Heritage" $27: 228$.

Irbid.

${ }^{3}$ Arthur Niehoff, "The Survival of Hindu Institutions in an Alien Environment, " Caribbean studies, 5, no. $36(1965): 176$. 
is favorable and not regarded as slightly less polluting than pork, as it is by the orthodox Hindus in India.' Hindus believe in evil forces which are gods with negative intent, attitude, and nature. These are necessary in order to manifest the gracious and benevolent nature of the good gods. In Trinidad, as a result of the influence of African and European religions and their attitude of fear and suspicion of the evil forces, the Indians are very much afraid of these hostile forces. ${ }^{2}$ Their fear is escalated by the fact that some of the evil and demonic forces they now have to contend with, like jumbees. sukuyans, obeah, maljo, and the evil eye, are new to them and to their religion. These forces are destructive and beyond the control of man. Therefore, the Hindu has to constantly seek for help to protect himself, his family, his job, and all his property from destruction and death. As a result, the pandit has to assume the role of a magician to deal with all these evils. In addition, the Hindu religious ceremonies and deities that offer the kind of protection needed are receiving substantially greater attention. Where these fail, the Hindus employ the services of mystical and magical practitioners of the Shango, Shouters, or European Christian faiths in order to find deliverance.

${ }^{1}$ Ibid.

2Morgan, 76 . 
Hindus have also incorporated some Christian practices into their religion. They annually participate in the La Divina Pastora celebration in Saparia where they even enter the Roman Catholic church and worship and anoint the black virgin. All saints night is also observed by some Hindus who light candles along the entrances to their homes and on the graves at the cemetery, if they have buried any relative. Pilgrimages are made to Mount st. Benedict, the headquarters of the Roman Catholic church, where Hindus comfortably worship and perform certain rituals. ${ }^{1}$

Since mystical stones cannot be had from India as desired by Hindus in Trinidad, it has been observed that

Stones are picked up even as they are in . . India as representations of Shiva lingam. Also living lingam stones, which are believed to be growing and to have miraculous powers, are discovered and enshrined. Pilgrimages are made as they are in India to the seashore, to rivers, and to the northern range of hilis which are equated to the Himalayas. 2

Apart from these differences and minor syncretistic incorporations, Hinduism in Trinidad, in general, is quite similar to Hinduism in India. When one examines Vidyarthi's catechetically designed book what Every Hindu Must Know, which was written in Trinidad and

\footnotetext{
${ }^{1}$ Niehoff and Niehoff, 75.

'Ibid., 287.
} 
dedicated to his family and those who have participated in preserving Hindu culture in Trinidad, it is evident that Hinduism generally has been preserved, and that a deliberate effort is being made to revive and restore Hinduism to its truly Indian model.

\section{Differences and Similarities between Hinduism and Seventh-day Adventistism}

Whenever an attempt is made to compare two religions or denominations, the basis used is usually an analysis of their fundamental beliefs. Nevertheless, it is always a tedious task to justly analyze and classify these beliefs, since each part of a religion impacts on and informs all the others as well as the whole system. As an attempt is made to compare Hinduism, a religion, with Seventh-day Adventistism, which is an exclusivistic Christian denomination, the challenge becomes increasingly difficult. Since Hinduism is complex and inclusivistic in nature, the difficulty is intensified. Bowker has pointed out:

To summarize the thought of any religion is difficult, but in the case of Hinduism it is impossible. It is the essence of Hinduism that there are many different ways of looking at a single object, none of which will give the whole view, but each of which is entirely valid in its own right.

In addition, the fact that

'John Bowker, The Problems of suffering in Religions of the World (Cambridge: The University Press, 1970), 193 . 
the acceptance of diversity in religion as having positive value and importance explains why it is impossible to give a systematic account or summary of Hinduism: to attempt to do so would contradict its very nature. What is essential in Hinduism is that each individual should act with integrity, seeking to appropriate what is true for himself on what ever level he may be.

The problems being what they are, what is done here is to select certain concepts and words that have some meaning and relevance in both Hinduism and Seventhday Adventism to compare their significance and specific differences. At the same time, major similarities are highlighted.

God

Hinduism seems to subscribe to a type of monotheism. However, the supreme is presented as philosophically nebulous, beyond description, comprehension, and conception. It is seen as beyond time and space, unavailable and uninvolved in the affairs of this world. It is called Brahman and is invisible, unchangeable, beyond the scope of good or bad, righteousness or unrighteousness. Brahman cannot be known, nevertheless, It is.

Seventh-day Adventists believe in one supreme God who is "immortal, all-powerful, all-knowing, above all and ever present. " 2 . Though He is infinite and beyond

${ }^{1}$ Ibid., 194

${ }^{2}$ Seventh-day Adventist Yearbook (1987), 5 . 
absolute comprehension by the finite mind, yet He can be known through $\mathrm{His}$ self-disclosure and special revelation which He makes in different ways in different places and at different times. This revelation indicates that He is love and not hate, good and not evil, and from His love and goodness He provides for the salvation of the human race to eternal good and glory.

\section{Trinity}

Though Hinduism advocate a trinitarian theology, a closer examination reveals that Brahma, Shiva, and Vishnu are different manifestations of Brahman, governing delegated responsibilities. Furthermore, the other socalled gods are sub-manifestations of this Hindu triad and their wives. In addition, all of creation is an extension of Brahman called Maya.

For Seventh-day Adventists there is a trinitarian doctrine which teaches that though God is one, there is a trinity comprising of three distinct persons. They are the Father, the Son, and the Holy spirit. All three are equally God and perfectly united. In other words, Seventh-day Adventists advocate a monotheistic trinitarian theology.

\section{Scripture}

Hinduism accepts the Vedas as their initial authoritative scripture that was revealed. In addition, 
there is extensive other religious literature. Once any of these concur with the Vedas, they are equally boni fide scripture for Hindus. A Hindu is free to use any one of these. Though the Vedas is the basic document, it is read only by the Brahmins. The scripture most commonly known and used by most Hindus is the Bhavagad Gita.

on the other hand, Seventh-day Adventists believe in one authoritative, infallible Holy Bible. This is a compilation of God's specially revealed will for all mankind for all ages. God, through special and deliberate revelation in different times in different places, made His will known to chosen men. They in turn wrote or had the revelation written down. In the Bible is found not only all that is necessary for securing salvation and developing a Christlike character, but the basic principles necessary for living successfully in this world. They place no other religious literature on equal footing nor do they have the absolute authority of the Bible which is held to be the Word of God.

\section{Worship}

Apart from designated days for specified pujas, Hindus do not have a set time, day of the week, nor place where they assemble as a congregation for public worship-even at the temple. Worship is a private or family affair. It is ritualistic and spiritual, not necessarily intellectually stimulating. 
Though Seventh-day Adventists strongly encourage private and family devotions, these can never take the place of public worship which is an absolute necessity. Public worship is conducted every saturday during specified time periods. In addition, weekly worship services may be conducted on other days.

\section{$\sin$}

Hindus view sin as ignorance that results from a lack of proper knowledge. This type of ignorance is responsible for all the problems in the world today. BY acquiring proper knowledge and the faithful performance of one's dharma, the problem of sin is dealt with by the sinner.

Sin is conceived by Seventh-day Adventists as the transgression of God's law or His revealed will. This results in an offence against God and at times against other persons. Sin also causes a break in relationship with God. Man or woman is powerless to do anything to deal with the sin problem which will eventually destroy him or her. His or her only hope is in God's intervention.

\section{Creation}

Hindus take the position that at the beginning of a particular era Brahman through Vishnu manifested himself as Brahma. Brahma in turn agitated and organized 
the already existing elements and created the world. It will last for four billion years during which time it will be preserved by vishnu. At the end of that time it will be destroyed by Shiva and absorbed by Vishnu. A state of none-creation will exist for another four billion years, after which another creation will take place. This cyclical process will continue indefinitely. All that is seen in creation is unreal. At the same time, it is an extension of Brahman called Maya. Only Brahman is real. Seventh-day Adventists believe that God, at a specific time in history, created this real world out of nothing, in six literal days, and rested on the seventh day, having completed His creation. At the time of creation, every thing was perfect. Subsequently, sin entered this world and marred its perfection. Despite that misfortune, God still sustains the world and is actively involved in the affairs of humanity. One day He will intervene and terminate the sin problem and its effects. Then He will restore this world to its perfect pre-sin state and it will continue in a state of celestial utopia eternally.

\section{Humanity}

Hinduism advocates that all persons are created equal, in terms of their physical composition. Due to the laws of Karma, individuals became socially classified and 
must remain that way until reincarnation when a change can take place, either up or down the social ladder.

A person is made up of a physical body which is destroyed at death, a subtle body, and a soul which are eternal. After death, the latter two, according to the dictates of the laws of Karma, enter a designated body by the process of reincarnation. This process will continue until Moksha is realized.

Seventh-day Adventists take the position that all persons are created equal, and each is a living soul. An individual is an inseparable complete being. At death the breath returns to God and the body is destroyed. The individual ceases to exist thereafter. When Jesus returns to finally deal with the sin problem, all persons who have died will be resurrected. They will then be rewarded, based on the relationship each had with Jesus when each lived. The unrighteous will be eternally destroyed, but eternal unending life will be the reward of the righteous.

\section{Salvation}

Hinduism teaches salvation by works or ways. There is the way of knowledge--juna yoga, the way of devotion--bakti yoga, and the way of rituals--kama yoga. As each person faithfully performs the duties of his prescribed yoga, he enhances his chances of some day experiencing moksha. 
For Seventh-day Adventists, salvation is by grace made possible through Jesus Christ. This salvation a repentant sinner accepts by faith and lives a life thereafter doing God's will through the enabling grace which He provides. As long as one maintains that relationship, he or she is saved to live with Jesus thereafter.

\section{Evangelism}

Hinduism is inclusivistic and syncretistic by nature and, therefore, it has no concept of proselytizing. One is born a Hindu. Samsara and the laws of karma negate any necessity for conversion. Furthermore, Hinduism teaches that there are several roads to the one common destination, and every man should chose the one that he considers best for him or her. In the end all roads will come together.

Seventh-day Adventists, being very exclusivistic, believe that there is only one way to a person's eternal destination with God. Consequently, it encourages and persuades all persons everywhere to get on that way which is Jesus, and which Jesus has provided. All other ways lead to destruction.

Though Seventh-day Adventists and Hinduism have practices and teachings that may have common classification and appear superficially similar, in reality there is no similarity. The differences are 
irreconcilable. There are two grounds that were not discussed, where there is some similarity. These are vegetarianism and the maintenance of a strong family. The family has only in recent years been incorporated into Seventh-day Adventist's fundamental beliefs but, at the same time, it is not a part of the syllabus used for preparing candidates for church membership. It has long been advocated that the maintenance of a strong family is a practice members should adapt. Vegetarianism in not a part of the fundamental beliefs but this life style is strongly encouraged by the Seventh-day Adventist church. Though the theological and philosophical basis for these beliefs are different, this does not seriously affect their similarities. Consequently, these form an adequate premise where Seventh-day Adventist can establish relationship or begin dialogue with Hindus.

\section{Conclusion}

When East Indians arrived in Trinidad, Hinduism was not encouraged; rather, indirectly, it was suppressed to some degree by prevailing circumstances. Nevertheless, with the advent of the 1930s, conditions began changing and the situation became more favorable to the advancement of Hinduism. This period witnessed the struggles for nationalism in India, and the charismatic leadership of Ghandi and Nehru there had a positive influence on the self-image of East Indians in Trinidad. During the same 
time, East Indian youths in Trinidad were being educated and, as a result, were securing prominent jobs and climbing the socio-economic ladder. East Indian schools were being established with Indian teachers, prominent temples were being built, cremation was legalized, and contacts with India were being strengthened. These events significantly contributed to the development of Hinduism to such an extent that it has become the second largest religion in Trinidad. It has also become, probably, one the most influential subcultures, so much so that Devali, one of its religious festivals, has been accorded the status of a national religious holiday--like Easter and Christmas for the Christians.

Hindu religious beliefs are many and varied. Worship is of a very private nature. The inclusiveness and the syncretistic nature of Hinduism have contributed to both its complexity and persistence in Trinidad.

Hinduism in Trinidad and in India, especially north central India, are very similar. The variations and adaptations are culturally and geographically conditioned. Other significant differences seem to result from the trend among Hindus in Trinidad to place more emphasis on those religious activities that appear to produce immediate and material rewards and protection.

When compared with Seventh-day Adventists it appears that the major religious beliefs and practices 
are, in fact, incompatible and irreconcilable. This is apart from the belief concerning the family and vegetarianism which are similar despite basic theological differences.

As a result, it is difficult for seventh-day Adventists to attempt to evangelize Hindus. Since there is an apparent chasm between their religious beliefs, the evangelistic approach cannot be purely religious for this tends to be divisive. Moreover, Hinduism, which is syncretistic, can embrace aspects of Seventh-day Adventism as an added part of itself. It is, therefore, important that in order to evangelize Hindus, Seventh-day Adventists learn to differentiate between Hindu religion and culture. Then they need to create a strategy, that will facilitate the replacement of the religion and be sympathetic with and respectful of the culture. This is discussed in more detail below. 
CHAPTER IV

REVIEW OF SELECTED LITERATURE

\section{Introduction}

This chapter reviews selected literature which assisted in formulating and developing an appropriate strategy for the evangelization of Hindus in Trinidad. The first section concentrates on Hindu sociocultural patterns. Here significant peculiarities which can create obstacles to a traditional Western style of evangelism are highlighted. Section 2 surveys concepts of culture and generally prevailing attitudes toward cultures.

Because sections 1 and 2 indicate a need for making appropriate adjustments to the methods of presenting the gospel to Hindus, matters of indigenization and contextualization are considered in section 3 .

The survey in section 4 considers relevant matters pertinent to Christian/non-Christian dialogue.

Attempts at evangelizing Hindus with the use of some of the principles of indeginization, contextualization, dialogue and the gospel and culture is given attention in section 5. Finally, the general conclusion 
summarizes the entire chapter and distills the principles that are deemed helpful to this project.

\section{Hindu Socio-cultural Patterns}

Art

Hinduism is an all-embracing religion. As a result, there is no aspect of a Hindu's life that is not informed and directed by Hinduism. In discussing culture, but with particular emphasis on the subject of art, Kinsley states that "Indian culture is so saturated by Hinduism . . that nearly all Indian art may be considered religious in one way or another." 1 Consequently, it is not surprising that at all levels, art substantially focuses on deities, religious themes, and religious scenes.

Initially, art was perceived as being so much of religion that the author further observes:

In texts on sculpture, architecture, painting, poetry, drama, and music, art is said to involve spiritual techniques or rituals on the part of the artist. It is therefore no exaggeration to say that until very recently religion and art were hardly distinguishable from one another. . .

Kinsley also notes that the complexity, diversity, and richness that characterizes Hinduism are evident in art forms. This ranges from a rustic, rural artistry to an

\footnotetext{
${ }^{1}$ Kinsley, 64 .

${ }^{2}$ Ibid.
} 
elaborate sophistication in temple designs. In the construction of temples, two shapes assume great prominence and significance. These are the circle, which depicts perfection, holiness, and the state of man, and the square, which represents the natural ordering and perfection of things.

Kinsley further notes that the creation of the world by Vishnu is the subject of primary interest for artists. ${ }^{1}$ In addition, they produce depictions or explanations and commentaries on Hindu religious teachings and conceptual portrayals of deities.

\section{Drama and Dance}

Relative to drama and dance, Kinsley indicates that they are also fully religious activities. ${ }^{2}$ In such process, the focal concern of the dancer or actor is to as far as possible, replicate the movement of a particular deity as is articulated in the Natya Shastra, which is

a book on dances that traditionally is held to have been revealed by the god Brahma. Each gesture described in the book is believed to be patterned on the gesture of the gods. Each emotional mood is to be expressed with the appropriate eye movement, figure gesture, posture of the body, and so on. To accompany these gestures the dancer-actors also are instructed to identify themselves mentally and emotionally with the characters they are

$$
\begin{aligned}
& \text { 'Ibid., } 66 . \\
& \text { 2Ibid. , } 67 .
\end{aligned}
$$


portraying, usually a divine or legendary being.

The author has stated that only after rigorous training and appropriate practice is the dancer ready to perform with precision. The importance of developing this kind of expertise can be appreciated, since the act is of a religious nature. During the performance, the goal of the actor is to so perfect his or her portrayal that the audience should be aesthetically transported temporarily to realms of spiritual bliss, similar to that experienced by the hermits and the sages. ${ }^{2}$

These cultural forms are of such high religious and spiritual esteem that Kinsley concludes that

To the extent that Hindu art seeks to express divinity or to enable the one who appreciates it to transcend human limitations, we can say that Hindu art aims at revelation. The artist, ideally, seeks first to identify fully with the divine image, character, or scene to be depicted and then reproduce it so faithfully that the one who perceives it is enabled to glimpse the divine. In this way Hindu art seeks to re-create heaven on earth by making the divine immediately perceptible. ${ }^{3}$

In addition to concurring with what has been discussed thus far, Younger and Younger ${ }^{4}$ indicate that music and dance perform a prominent role in Hindu

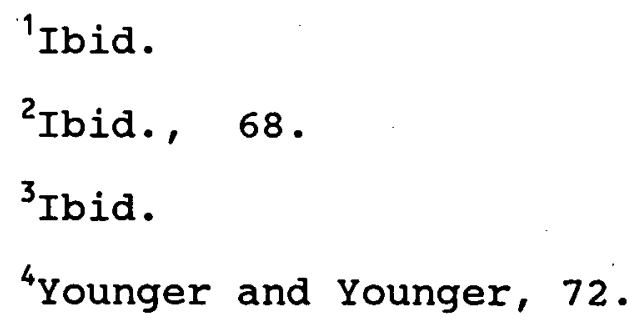


festivals and ceremonies due to their influence on the emotions. They also state that

Dance . . . is not a social phenomenon but is usually a highly developed and sophisticated form of religious art. There is a rich variety: the joyful folk dances of the tribal people, the complex dramatic dances of religious festivals (Kathakali of Kerala being the beat known), and the sophisticated abstract expression of bharata natyam (dance of India).

The bharata natyam dances are considered the most popular because they are performed to portray Vishnu's ten principal avatars. Therefore, Hindu dance and cultural forms are not ends in themselves; they are vehicles designed to convey spiritual "truths" or to elevate both the spectator and the actor spiritually.

\section{Marriage}

Morgan deals with marriage when discussing the second of the four stages of a Hindu male's life, the house-holder or the Girhastha. ${ }^{2}$ He indicates that marriage, from a purely religious point of view, identifies the male's beginning of a purposeful and responsible life. Socially, marriage ensures the ancestral perpetuation through the birth and upbringing of children.

Younger and Younger, who discuss marriage under the sub-section "Religious Ceremonies, ${ }^{3}$ suggest that the

${ }^{1}$ Ibid.

${ }^{2}$ Morgan, ed. , 138-141.

${ }^{3}$ Younger and Younger, 70-72. 
marriage of the children is the responsibility of the parents. They, not only have to find an appropriate partner, very much independent of the desire of the child or children concerned, but they (the parents) process the entire marriage ceremony. As a result, generally, for the couple in question the marriage is the beginning of a new love relationship. Since marriage is a simskare--that is a religious rite--no vows are explicitly exchanged as in the Western context. However, one might view the entire process as an exchange of vows. The wedding ceremony is performed by the parents of the couple, some relatives, and the brahmin priest who does the relevant chants, invokes the deities, and pronounces the desired blessings on the couple. The joining of the couple is symbolized by the tying of the sacred thread which is called a thali. Upon the completion of this rite, the groom's immediate relatives replace the bride's relatives who are positioned behind her signifying that she, from that moment on, belongs to the groom's family.

While discussing the subject of marriage, Chandy suggests that

In the Hindu marriage ritual, too, the bride is thought to become one flesh with her husband. She acquires the same bodily substance. After her marriage all her children assume the bodily 
substance of the father and his relatives. .

He further states that marriage is of singular importance in the life of the average Hindu and is vital to the existence of the extended family and caste. Therefore, the finding of the best mate coming from the right family and the same caste is of utmost importance.

Proper marriage alliances, namely marrying within the same group, are of great importance since this expands the chain of relatives, which in turn increases the power and prestige of the family. Having a wide circle of family members is also one way of acquiring more wealth. 2

However, on the contrary,

A wrong marriage alliance can disable and discredit a family for life. Since marrying into another jati will result in severe repercussions, each family is ruthless in preserving its own identity and entity. ${ }^{3}$

Chandy recognizes that there are four ways by which marriages are arranged among some Hindus. The first is the traditional marriage which is quite frequently used. Here the elders of the family concerned generally meet in consultation with prominent village folk and, thereafter, process the entire wedding arrangements for their children.

${ }^{1}$ Verghese Chandy, "Obstructions and Strategizing in Church Planting among Tamil Hindus in Sri Lanka" (D. Miss. dissertation, Fuller Theological Seminary, 1984), 60.

$$
\begin{aligned}
& { }^{2} \text { Ibid., } 62 \text {. } \\
& { }^{3} \text { Ibid. }
\end{aligned}
$$


The cross-cousin marriage is the second type of marriage arrangement and is relatively popular. The children of brothers and sisters may marry each other. However, the children of two sisters may not marry. This cross-cousin marriage arrangement guarantees the family wealth and property remaining with the family.

The third arrangement is the double wedding, where a brother and his sister marry the brother and sister of an unrelated family. This arrangement negates the need for any dowry.

Love marriage is the fourth kind. A relationship develops between the couple, and when the parents are informed, they pursue the arrangements for the marriage.

Chandy underscores the fact that a properly celebrated marriage must have the active involvement of both sets of the immediate families. The marriage actually begins with the grain-planting ceremony at the home of the bride's parents by some elderly women. Nine grains are put into a hole dug for that purpose and then milk is poured over all. If the grain sprouts within a few days, it is thought to be a good omen. 1

When the wedding day arrives both bride and groom are ceremonially bathed by their respective close relatives. Following that, the other features of the

$$
\text { 1'Ibid., } 64 \text {. }
$$


marriage occur and may continue for days. The longer the marriage ceremony and accompanying celebrations lasts and the more elaborate and impressive they are, the more it confirms the wealth and the prestige of the family, which will forego everything to create this favorable impression. ${ }^{1}$

Basham, ${ }^{2}$ in highlighting the religious obligation imposed on the Hindu male to get married, establishes the point that apart from when a celibate vow is taken, marriage is performed as an obligatory duty for

- . the promotion of religion by the performance of household sacrifices; progeny whereby the father and his ancestors are assured of a happy after life, and the line was continued; and rati, or sexual pleasure. ${ }^{3}$

Another peculiar phenomenon in Hindu marriages Basham discusses is the marrying of early teen and preteen-age girls. This is largely due to a religious conviction--the desire to avoid sinning. One school of thought advocates that if a girl were allowed to have her initial menstruation while yet unmarried, it would be considered that her father had sinned because he had deprived her of the possibility of having a child as soon as she was able to do so and this is considered as

'Ibid., 64 .

${ }^{2}$ A. L. Basham, The Wonder That Was India (New York: Grove Press, 1959)

$$
{ }^{3} \text { Ibid. , } 165 .
$$


securing an abortion.' This is one of the five most grievous sins. ${ }^{2}$ The father continues to sin for each succeeding menstruation the girl has, as long as she is yet unmarried. Another school of thought suggests that girls should marry at an early age in order to ensure that she has maintained her moral purity. This is due to the belief that girls are thought to be "naturally libidinous" and will become irresistibly sexually involved upon the onset of puberty. ${ }^{3}$ Therefore, in an attempt to forestall such potential behavior, which could result in the parents being disgraced, and because of the possibility of the girl becoming unmarried indefinitely, or even worse, becoming a prostitute, the parents try to marry off the girls at an early age.

Basham also agrees that the wedding ceremony is complicated and expensive, especially to the girl's parents. Though the rules for the details of the marriage

\section{${ }^{1}$ Basham, 166 . \\ ${ }^{2} \mathrm{~J}$. A. Duvois, Hindu Manners, Customs and}

Ceremonies (Oxford: Clarendon Press, 1906), 197.

The unpardonable sins are five in number:

1. Brahmahattya, the murder of a Brahmin.

2. Sisuhattya, the destruction of an unborn child, i.e., wilfully causing an abortion. tree.

3. Surapana, to drink toddy, the juice of the palm-

4. Swarna-Sneya, to steal gold.

5. Guru-talpa-gamana, to have sexual intercourse with the wife of one's guru or of one's spiritual or temporal superior.

$$
{ }^{3} \text { Basham, 166-167. }
$$


vary according to the different textbooks used, the rite usually conforms with the Rg Veda.

The marriage takes place in a temporary pavilion in the family's yard. The groom, decked in "great finery" and in the company of his friends and relatives, in a procession is transported to the bride's home. There, her father welcomes the groom by offering him a special drink of honey and curds. The bride and groom enter the pavilion separately and are seated with a curtain between them. At the appropriate time, the officiating brahman or priest repeats a few verses and then removes the curtain. Then the bride's father gives the bride to the groom who promises his faithfulness to her. offerings are then made to the sacred fire during which time the groom takes the bride by the hand and leads her around the sacred fire. The couple are next sprinkled with holy water--as the main part of the ceremony. The couple then return to the groom's home where more sacrifices are made. For the first three nights following their marriage, the couple refrain from any intimate relationship. However, immediately thereafter, the marriage is consummated. For the Hindu family, and society, marriage is imperative. It guarantees the benefits of the family in this world and in the world to come. Therefore, the entire family strenuously resists any threat that tends to 
destabilize the possibility for the marriage of any of its children.

\section{Family}

The family is the most important socio-cultural institution in Hinduism. This is due partly to the fact that the family is where acculturation and religious orientation take place.

Chandy establishes the fact that marriage is a religious obligation and liberation is realized through the maintenance of correct relationship within the family circle. The wife who is considered a gift from God is subservient to her husband beside whom she loyally carries out her responsibilities.

\section{The absence of children from a marriage} indicates the presence of a curse, and that the marriage is incom-plete. Children are essential, since, for example,

- . the eldest son plays a very unique role as savior of the father. When the father dies, he [the son] performs certain rites that ensures the father's deliverance from hell. . .

In addition, when each member of the family preforms the assigned dharma, the family is guaranteed spiritual wellbeing in this world and the next.

${ }^{1}$ Ibid. 
The family may live on one common property as an extended family or as a number of nuclear families. In the family arrangement, the welfare of the family as a unit takes precedence over that of the individual. For that reason an elder daughter sometimes will forego marriage so as to work for money to pay for the dowries that ensure that her other sisters will get married.' In the Area Hand Book for India, ${ }^{2}$ it has been suggested that the "ideology of Indian family life generally emphasizes the continuity and solidarity of the male line." 3 since property is passed down through the line, the resulting family residence is a patrilineal extended family. In the ideal situation, the family lives together in a composition of three generations and is sustained and maintained from a common sources. The family members, as a practice, give allegiance to the eldest male in whom is invested the family's authority. The men in the extended family form the skeleton of that community. The females born into that family are participants only until marriage. Those who enter by virtue of marriage may be at a lower social standing in

\section{${ }^{1}$ Chandy, 70.}

${ }^{2}$ Richard F. Nyrop, Beryl Lieff Benderly, william W. Cover, Melissa J. Cutter, and Newton B. Parker, Area HandBook for India (Washington, D. C.: American University, Foreign Area Studies, 1975), 196-211.

${ }^{3}$ Ibid. , 196. 
the family than the daughters. The new bride, nevertheless, makes this new family her home for life. Despite the effects of modernization, the Hindu family is hierarchically structured, and age determines the status level of the males. When a female enters a family through marriage her entire life, even her relationship with her husband, is directed by her mother-in-law. However, in addition to the acquired status from her husband, a wife in the family can enhance her position by becoming a mother, especially of sons.

The Hindu extended family is classified by

Aileen D. Ross as the traditional joint family which, together with other social units, "form the core of the traditional Hindu society." ${ }^{1}$ she notes that this family design has been in existence as long as Hinduism. According to Ross, the ideal joint family is much easier to describe than to define.

The joint family is comprised of separate family units, each having two rooms in one great house. They share one common kitchen, one worship room, and spend from one common purse. In the event of overcrowding, two of the brothers may move out to an adjacent site, usually on the same property, and set up an independent dwelling which becomes the nucleus for another joint family.

'Aileen D. Ross, The Hindu Family in Its Urban Setting (University of Toronto Press, 1961, reprinted in the United States of America, 1962, 1967), 3. 
The joint family work is assigned according to age and sex. The domestic work is done by the females under the direction and tutilage of the eldest woman in the family. Women are also responsible for all the indoor work including the daily religious activities. The males take care of all the outside work and the support of the family. Where the family's land holding is small, the senior male or the senior son cultivates it while the other men work elsewhere in order to provide needed finances to supplement the produce from the land. The finances earned are pooled and administered by the senior male in the interest of the family and as the needs demand, not according to the contribution made by each male.

The property belongs to the family and is handed down from father to sons. As a general rule, daughters do not share in their father's property; however, a daughter may share in her mother's property.

In its operation, the extended family

is family centred, characterized by intimate mutuality of interest, strong primary group controls and mutual assistance in time of need. In it family tradition and pride are strong and individual members are dominated by the opinion of the larger group.

Family authority and administrative structure exist in the hierarchical model with the powerful senior

\footnotetext{
${ }^{1}$ Ibid., 14
} 
male at the apex of the pyramid. Authority is distributed among the males in descending order according to age. Though the females are usually subservient to their males, an older sister may have authority over a younger brother until he becomes an adult. Family authority is respected to the extent that when the children become adults, they tend to continue to submit to the center of authority relative to the decisions and choices they make.

Ross also notes that in the nuclear family there is significant difference with respect to the outlay of authority. In the nuclear family arrangement, when a son becomes a husband and sets up his own family he becomes independent of his father. Similarly, in this new family the husband shares his authority with his wife, who is more independent of her husband and mother-in-law than a wife in the extended family unit. In addition, even the children tend to be more independent and demonstrate this by initially making decisions regarding matters which are inconsequential and then progressively deciding on issues which eventually become more complex.

In the joint family, relationship between members is by no means always positive. Generally, the closest relationship exists between a mother and her sons. second to that is the relationship between brothers and sisters. The relationship with the most apathy usually exists between a mother-in-law and her daughter-in-law. 
Because of possible implications of these relationships and the effect they may have on the family,

The stability of the joint family could not be allowed to disintegrate because of the personal feelings of family members, for it was the main stable unit of society in which it existed. The relationships of the various members had, therefore , to be carefully maintained and were built up through attitudes of respect, fear, obedience and avoidance as well as love.

Despite the strength of the joint family among

Hindus, both external and internal elements determine the state of its existence, as Ross suggests:

Many factors are contributing to family decision to remain together or apart. Economic conditions and quarrels have always affected family size. New factors which are now important in encouraging smaller family households are: widespread opportunities for higher education, heightened ambitions, increased occupational mobility, desire for higher standard of living, more independence. on the other hand, there are still many factors which are helping to maintain the older family forms. Traditional attitudes of affection and responsibility do not give way easily, and are still supported by much of the Hindu way of life, which has not yet changed enough to alter the former patterns. Moreover, economic insecurity is still so prevalent that many families must remain together that might have otherwise desire to break up. ${ }^{2}$

\section{Gospel and culture}

The Bible was written in a particular cultural setting that was significantly influenced by the semitic and Greco/Roman thought patterns. However, Christianity,

$$
\begin{aligned}
& \text { 'Ibid., } 177 . \\
& { }^{2} \text { Ibid., } 50 .
\end{aligned}
$$


to a large extent has been developed in a Western cultural milieu. In the process of its development, Christianity has adopted and molded itself so much according to Western culture that western culture is at times recognized as the right or christian culture, and other cultures are thought to be wrong and even heathen. Consequently, in spreading the gospel, clashes have arisen between Christianity and cultures. This is mainly due to the failure of many to distinguish the truth of the gospel from its cultural wrappings or the vehicle that conveys it.

Pentecost,' who discusses the problem, suggests

that in presenting the gospel,

- . rather than try to interpret scripture, it is far more preferable to translate the truth and teach the significance of the truth conveyed. For example, instead of trying to change the sacrificial animal from a lamb to a chicken because the recipient group only knows chicken sacrifices, it is far more meaningful to translate the truth, and teach the significance of the point under discussion. ${ }^{2}$

He then continues by defining culture as a system that directs life and gives it its proper meaning. Therefore,

If those points are destroyed, man is left to drift on a sea of insecurity. To destroy culture is to destroy a way of life or design of living. To divest man of culture without offering a functional substitute is to place

'Edward C. Pentecost, Issues in Missiology (Grand Rapids, Michigan: Baker Book House, 1982).

${ }^{2}$ Ibid. , 34 . 
man in a vacuum where he finds only frustration.

Pentecost then advances the argument that

culture has three inter-related levels or components, the physical, the social, and the philosophical. Though they are distinct, there is an experiential point where they all overlap and interact. This

- . is that point of greatest strength for the culture itself, and here the individual finds greatest stability. Material areas may change without seriously affecting the people within the culture, until the change is seen to affect the point where the social and spiritual areas are also affected. Then there is resistance to the intrusion. ${ }^{2}$

Therefore, it can be better understood why some people, especially those for whom religion is not only a way of life but informs all of life's activities, are indifferent to the average invitation to accept christianity.

McGavran ${ }^{3}$ also considers culture, but from the view point of the Christian missionary. He advances the argument that the prevailing attitude of christianity to other religions as it proclaims the gospel is influenced by its concept of the origin and the degree of divine involvement in cultures. With respect to the relationship between God and cultures, he lists five positions:

\footnotetext{
${ }^{1}$ Ibid., 79.

${ }^{2}$ Ibid., 83 .

${ }^{3}$ Donald McGavran, The clash between Christianity
} and Cultures (Washington, D.C.: Cannon Press, 1974). 
1. Cultures are the creation of man.

2. God participated in creating the cultures of humanity by guiding the development and changing of society and the relevant adjusting of culture.

3. Man is sinful, therefore, culture is sinful and a righteous perfect God is not responsible.

4. As man becomes a disciple of Jesus and follows Him and His word, inherited cultures are changing to become more in conformity to God's will.

5. All cultures are under the judgment of God.

6. As people come in contact with the gospel, there will be some changes in some aspects of culture. Therefore, Christians in different places will be different, yet at the same time they will possess similarities in areas of biblical instructions and requirements. 1

McGavran also observes that not all aspects of all cultures are compatible with the gospel. However, in resolving the conflict between the gospel and cultures, the Bible must be the standard by which any determination is made. Then it can be determined what aspect of cultures are to be kept, what aspects are to be adjusted, and what aspects are to be replaced.

He also argues that the real clash is not with culture per se but with components of culture. Some of

${ }^{1}$ Ibid., 10-13. 
these are welcomed by Christianity, some are improved upon, and the smallest portion is abandoned.' However, McGavran sees that the clash between Christianity and cultures may be resolved by holding elevated views of scripture and cultures ${ }^{2}$ and allow for differences of opinion, since, as he says,

- . the meaning of cultural components changes with circumstances, and biblical principles apply to what acts mean in specific context. Consequently, in all such adjustments, differences of opinion are inevitable. When there is no clear biblical directive, Christians have to do the right as they see the right.

In Hinduism all of life is considered religious in the sense that there is no difference between the sacred and the secular. Hence the socio-cultural patterns are really religious patterns and participate in maintaining the cosmic order. In addition, the gospel is considered acultural. These two facts suggests the need for adjustment to the method of presenting of the gospel to the Hindus. Consequently, it has become necessary to examine matters of contextualization and indigenization which can assist in informing the process of evangelism.

\footnotetext{
'Ibid., 38-42.

I'Ibid., 74 .

${ }^{3}$ Ibid. , 76.
} 


\section{Indigenization and contextualization}

Indigenization

"Indigenization" comes from the word

"indigenous" which suggests that which normally lives or exists and functions in its own and original environment. According to Shoki coe, this idea is really derived from a metaphor of nature which involves 'taking root in the soil. 1

As it relates to the gospel and missions, indigenous could suggest communicating the gospel in such a way that it becomes substantially native and a compatible component of the socio-cultural fabric. While this is true, the gospel must maintain its original spirit, intent, and content. This fact always should be kept in focus since

- . indigenization is a missiological necessity when the gospel moves from one cultural soil to another and has to be retranslated, reinterpreted and expressed afresh in a new cultural soil.?

Despite the appeal for indigenization, coe believes that certain pitfalls seem possible, as he observes,

because of the static nature of the metaphor, indigenization tends to be used in the sense of

${ }^{1}$ Shoki Coe, "Contextualizing Theology," in Mission Trends No. 3, ed. Gerald H. Anderson and Thomas F. Stransky (Grand Rapids, Michigan: William B Eerdmans Publishing Co. and Paulis Fathers, 1976), 20.

${ }^{2}$ Ibid. 
responding to the gospel in terms of

traditional culture. Therefore, it is in

danger of being past oriented. The new context

is not that of static culture, but the search

for the new, which at the same time has

involved the culture itself."

Taber $^{2}$ recognizes indigenization as a positive but limited and restrictive missionary process. It allows a foreign message to deliberately or accidentally assume features which are compatible with the recipient and his or her context. Indigenization could nevertheless, be either good or bad. It may be good in the sense of

making the message intelligible in terms of receptor categories of thought and imagery and relevant to the existential concerns of the receptor people.

Whenever indigenization confuses the gospel, or desensitizes its possible sharpness, or obscures those aspects of the gospel that are in conflict with basic cultural merit then it is considered bad.

Though Taber gives much credit to indigenization, he disqualifies the inherent static concept of the term and argues for a more dynamic model "which sees the gospel and culture meeting in the midst of a trajectory of change. $"{ }^{4}$

${ }^{1}$ Ibid.

${ }^{2}$ Charles R. Taber, "The Limits of Indigenization in Theology." in Readings in Dynamic Indegeneity, ed. Charles $\mathrm{H}$. Kraft, and Tom $\mathrm{N}$. Wisley (Pasadena, California: William Carey Library, 1979), 372-399.

$$
\begin{aligned}
& { }^{3} \text { Ibid., } 373 . \\
& { }^{4} \text { Ibid., } 375 .
\end{aligned}
$$


Taber also suggests that indigenization has been a step in the right direction, but it did not go far enough. ${ }^{1}$ To substantiate this position he enumerates the following points which are summarized here.

1. Indigenization limits its focus only on the cultural proportions of life.

2. Indigenization interprets culture in quite static terms, and shows little appreciation for the flexibility of cultures which are in constant reformation and modification.

3. Indigenization seems to view sociocultural systems as conclusive and encased.

4. Indigenization was defined as an event or process that occured only in the mission field.

5. Indigenization limits itself to superficial issues like the expression of a gospel as though it is common to all contexts.

6. Indigenization tends to relinquish limited authority and autonomy to the nationals. They may administer the missionary interprize but the large support institutions are financed and controlled by foreign interest. ${ }^{2}$

${ }^{1}$ Charles R. Taber, "Contextualization: Indigenization and/or Transformation," in The Gospel and Islam, ed. Don M. McCurry (Monrovia, California: Mission Advanced Research and Communication Center; 1979), 143154.

$$
{ }^{2} \text { Ibid., 144-146. }
$$




\section{Contextualization}

This impending danger of stagnation has

motivated some scholars like coe to choose to subscribe to the concept of contextualization which they see as equally dynamic as the societies being addressed. At the same time, it is viewed as a broad concept that embraces the implications of indigenization. According to coe,

in using the word contextualization, we try to convey all that is implied in the familiar term indigenization, yet seek to press beyond for a more dynamic concept which is open to change and which is also future-oriented."

Kinsler ${ }^{2}$ states that though contextualization is a word that has recently been developed, it has quickly found extensive usage in theological and mission circles. He also establishes the point that this word was initially used by Shoki coe and Aharon Sapsezian, as is suggested in one of Sapsezian's letters. Kinsler suggests that the concern of contextualization is the incarnation of the gospel, as it has been exemplified by Jesus in His life and ministry. Consequently, each person can receive and thus experience the benefits of the gospel in his or her cultural context. Though he sees in this basic concept the encapsulation of the concerns of indigenization, contextualization extends to broader horizons. It

IIbid., 21 .

${ }^{2}$ F. Ross Kinsler; "Mission and context: The Current Debate about Contextualization," Evangelical Mission Quarterly, 14, no. 2 (April 1978): 23-29. 
embraces the gospel while assuming "the forms and the idiosyncrasies of the different cultures but also maintains a critical stance and seeks to transform them." Contextualization also shows concern for the socioeconomic situations "in order to discover the full significance of the gospel in that situation." 1

Kinsler concludes that contextualization should harness the benefits of the social scientific disciplines to inform missions and ministry. This should make the Christian church a dynamic, progressive, and flexible body that is moving in step with the beat of life's rhythm.

Taber seems to support Coe's position that contextualization is of broader scope and more comprehensive in its operation. ${ }^{2}$ He argues that in contextualization there

is an attempt to capitalize on the achievements of indigenization, to correct its errors and biases, and fill in the gaps. It is the effort to understand and take seriously the specific context of each human group and person on its own terms and in all its dimensions--cultural, religious, social, political, economic--and to discern what the gospel says to the people and not the context. 3

In an attempt to establish a preference for the preeminence of contextualization Taber establishes the following points which are condensed here for convenience.

'Ibid., 25

2Taber, "Contextualization" 143-154.

${ }^{3}$ Ibid., 146 . 
1. Contextualizátion takes into consideration not only the cultural dimension of humanity but the social, political, and economic issues, like wealth and power, power and powerless.

2. Contextualization recognizes early cultural roots but also considers ongoing cultural transformation.

3. Contextualization places emphasis not on people in closed isolation but on the wider global context and the relative impact.

4. Contextualization does not limit itself to the activities of the mission field but sees in all cultures evidences of the demonic and the divine and the possibility of cultural confrontation or syncretism which should be addressed.

5. Contextualization also concerns itself with the universal dimensions relative to the gospel which are deep and diverse.

6. Contextualization advocates for the devolution of autonomy and authority to the nationals in mission. 1 Charles H. Kraft ${ }^{2}$ advocates that contextualization was practiced by the New Testament Church as it carried out the gospel commission among the non-Hebrew consti-tuents. He also sees contextualization

'Ibid., 144-146.

${ }^{2}$ Charles H Kraft, "The Contextualization of Theology," Evangelical Mission Quarterly 14 (1978): 31-36. 
as a continuous evolving process by those whom the gospel encounters, rather than an imitation of the practices of others. Kraft hastens on to underscore the fact that the basis for such contextualization is the Bible which provides the necessary parameters.

He further states that no theology ought to be considered absolute in the sense that all theologizing is a finite, human progressive process which is constantly being developed. Whenever an attitude of absoluteness is manifested, there is the assumption of superiority and supreme correctness by those who take this position. Kraft also mentions that there are risks with contextualization. There is the possibility of syncretism resulting from mistakes in trying to adapt the gospel to a given situation. The opposite possibility is denominational rigidity of orthodoxy and the concretization of theology. He maintains that contextualization of theology must be biblical if it is ever to be christian. He rightly suggests, for example, that

New Testament teaching concerning the superiority of the power of Christ to that of evil spirits is, for example, a much more prominent part of contextualized African theology than of American theology.

Because of cultural diversity, Kraft suggests it is imperative for Christians within every culture to be encouraged to contextualize their theology. This should

$$
{ }^{1} \text { Ibid., } 34
$$


be done in such a way that the people can perceive the gospel to be existentially relevant to the problems and concerns with which they struggle. For though the problems in essence are common to all cultures, their manifestations and the methods of solving them may differ greatly.

Krikor Haleblian ${ }^{1}$ has also reflected on contextualization. He takes the position that, tentatively, contextualization may by defined as the discipline which deals with the essential nature of the gospel, its cross-cultural communication, and the development and fostering of local theologies and indigenous church forms. In harmony with Coe, Haleblian also argues that contextualization is different from indigenization, in that contextualization is broader in scope. However, his concern is not necessarily with the traditional meaning of the words, but rather with the meaning that is informed by the context.

with respect to the problem of syncretism that results from efforts at contextualization, Haleblian takes issue with the reasons that have been suggested by others. He sees the primary reason for the problem as "the contex-

${ }^{1}$ Krikor Haleblian, "The Problem of Contextualization," Missiology: An International Review 11, no. 1 (January, 1983): 95-111. 
tualizer's inadequate grasps of the essential nature of the gospel."1

Though contextualization is necessary, there needs to be certain limitations in order to maintain a universal Christianity. Other authors have issued many guidelines for necessary limitations. Nevertheless, Haleblian concludes that

a contextualization of theology must be Christological or that it must affirm revelation and salvation effected in Christ. . - Christian theology, whether ethnic or not, is by definition Christological and cannot be based on anything but the salvation effected in Jesus Christ. ${ }^{2}$

Buswell, ${ }^{3}$ who has witnessed the retardation of the growth of the Christian church in India, has supported the need for contextualization. For him there must be contextualization of the witness, the church, and the word. The contextualized witness must, in the process of his operation, present a supracultural gospel, using the communication vehicle that the local culture makes available. This can be accomplished with the ministry of the Holy spirit and the assistance of the local converts. Buswell objects to Coe's static indigenization theory. He sees indigenization as a dynamic process that

$$
\begin{aligned}
& \text { 'Ibid., } 100 \\
& { }^{2} \text { Ibid., } 101 .
\end{aligned}
$$

${ }^{3}$ James 0 . Buswell III, "Contextualization: Is it only a New Word for Indigenization?" Evangelical Mission Quarterly 14, no. 1 (January 1978): 13-20. 
finds similarities in the ministry of christ and which is consistent with the dynamic nature of culture. Therefore, he believes that when missionaries advocate a return to traditional culture, they have in view some former aspect of culture as they perceived it. To this the local people object because it fails to fit with their dynamic life style.

In terms of the Bible and its translation, Buswell suggests that it has been done contextually. He advocates that the contextualization of theology always should be done from within the particular culture.

Contextualization is both an evangelistic and a missiological necessity. However, one should ensure that the dynamic aspect of this concept is maintained. At the same time, it becomes absolutely necessary to guard against the resulting evolution of syncretism. The Bible should provide the needed checks and balances to ensure that faithfulness to the gospel is maintained when contextualizing the very gospel and the method employed in disseminating it.

\section{Conclusion}

According to the review of the literature so far, there appears to be close similarity between contextualization and indigenization. In spite of this, there are differing views as to the relationship between these two terms. Kraft and Buswell seem to suggest that 
indigenization should be retained along with

contextualization. Coe and Taber, on the other hand, seem to prefer to replace indigenization with contextualization which he claims to be dynamic. Haleblian's advice of placing the emphasis on the contextual meaning of the words rather than on overt concern with the words themselves seem to be the best approach. Relative to evangelism, contextualization may be recognized as a process of communicating the gospel through methods and structures that are familiar to those being evangelized. In this process, though, the gospel is adapted to become meaningful and relevant to the prospective recipients. Since this approach allows for differences, the evangelists have to guard against two extremes; on the one hand is the possibility of syncretism, while on the other is denominational rigidity. As contextualization is attempted, the Bible ought to provide the necessary checks and balances that will ensure that the content and intent of the gospel are maintained consistently. These principles which are helpful when evangelizing people of other cultures can assist in developing a strategy for evangelizing the Hindus in Trinidad.

\section{Christian/Non-Christian Dialogue}

The vast world, where "approximately 75 percent of the people. . do not recognize the name of Jesus 
Christ, "1 poses quite a challenge to the Christian church as it tries to fulfill its mission. In an effort to comply with the gospel commission, the christian church embarked on an aggressive evangelistic campaign that many times coincided with European colonial expansionism. In the process, a christianity that was culturally conditioned to the European paradigm was imposed upon the indigenous people in European colonies. With the rise of nationalism and cultural pride, many former colonies are rejecting Christianity with European culture as an alien entity. As a result, there has been a reduction in evangelistic successes and an increase in the number and complexity of the obstacles that have impeded the progress of the gospel. Such a situation has caused the Christian world to re-evaluate its methods and activities. Consequently, it has been determined that the dialogical approach may be less confrontational and more appropriate and acceptable. Hence, within recent decades there has been a growing interest in Christian/non-Christian dialogue.

Swidler ${ }^{2}$ has defined dialogue as a conversation between two or more persons with differing points of view on a particular subject. Each party to the dialogue

\footnotetext{
${ }^{1}$ Dayton and Fraser, 35.

${ }^{2}$ Leonard Swidler, "Interreligious Dialogue: A Christian Necessity," cross currents 35, no. 2/3 (Fall 1985) : 129-147.
} 
listens with an openness that is willing to facilitate change or growth that can result from the demands of exposure to new data.

He further states that inter-religious dialogue is concerned not only with religious ideas, where the participants encounter each other as religionists with a particular religious perspectives and agendas, but, instead, each participant enters a religious dialogue as a person who is willing to disclose himself/herself from an internal frame of reference. Therefore, what is shared is personal, subjective experiences. It has also been noted that the participants in dialogue must be equal and selfcritical of his or her religious teachings and practices, so that in the process positive elements can be accepted from the other participant/participants in the dialogue.

Swidler further mentions that in the dialogical operation there are three phases. The first is concerned with unlearning errors and misconceptions as a result of exposure to new data. The second phase allows for the recognition of the positive elements and virtues of the other religion or religions. In the third phase,

together we begin to explore new areas of reality of meaning, of truth, of which neither of us had even been aware before.'

Another area of dialogue that has been highlighted by Swidler has to do with what he calls 
Deabsolutizing Truth. ${ }^{1}$ This operation is necessary because sociological, historical, linguistic, and hermeneutical contexts change. Therefore, corresponding truth about people changes, especially when it is descriptive. He then tries to balance this position by hastening to emphasize that the system of deabsolutizing should not lead to relativism. Rather, the search for truth and the truth of meaning calls for a viewing of issues from different perspectives and at the same time analyzing one's presuppositions. This approach facilitates a more complete concept of truth and meaning. Swidler also suggests that the very existence of religions and the inevitable interaction that has been created by current mass communication make the demands for religious dialogue inescapable. However, those who enter into such dialogue must be religious and conscious of their personal and religious context and the consequential impact of truth.

Swearer, 2 who shares some of Swidler's insight, advances the suggestions that one's attitude to dialogue is conditioned by one's attitude to the other religions. Based on certain biblical perceptions, historically Christianity has been an exclusivistic religion. However,

${ }^{1}$ Ibid., 131.

${ }^{2}$ Donald K. Swearer, Dialogue: The Key to Understanding other Religions (Philadelphia: Westminster Press, 1977). 
changes in the attitude toward other religions have been occurring on the contemporary scene, and as a result, attitudes can be classified in three basic categories. Swearer discusses these and prominent representatives of each attitude.

The first attitude which, according to Swearer, is supported by Hendrik Kraemmer is called "discontinuity." 1 This position advocates the view that Christianity is unique and different from the other religions. It is therefore superior by virtue of its revelation. Consequently, there is no room for dialogue. The only need for interaction is for the conversion of the other people.

The second attitude called "fulfillment" is subscribed to by R. C. Zaehner. ${ }^{2}$ This view recognizes that Christianity is the fulfillment of all other religions, which are subordinate to it. Despite that, other religions possess not only similarities to Christianity but vistas of the gospel of Jesus. Swearer, nevertheless, dismisses this attitude because by its very nature it negates the need for any dialogue.

William E. Hocking supports the third attitude, which Swearer calls "cooperation." 3 Religion is

$$
\begin{aligned}
& \text { 'Ibid., } 30 . \\
& { }^{2} \text { Ibid., } 31 . \\
& { }^{3} \text { Ibid., } 33
\end{aligned}
$$


recognized as universal and a natural outgrowth of man's quest for righteousness. All religions are in the process of growth towards "the religious essence." Christianity ideally embodies all other religions, potentially, and is in the process of attaining its complete fulfillment. Because of its inherent potential and qualities, Christianity is most qualified to be the leader of religions.

Swearer then goes on to say that the most recent approach to other religions has been dialogue, of which wilfred Cantwell Smith is an ardent proponent. ${ }^{2}$ This approach, which has become popular with the World Council of Churches, is defined not as a doctrinal or religious discussion; but,

First and foremost, dialogue is an encounter of religious persons on the level of their understanding of their deepest commitments and ultimate concerns. ${ }^{3}$

Swearer also concurs with Klaus Klostermaier's position, that dialogue is an encounter between human beings, each with his or her subjective faith.

After having discussed the basic attitudes to other religions, Swearer then outlines what he considers

$$
\begin{aligned}
& \text { IIbid., } 34 . \\
& { }^{2} \text { Ibid., } 35-40 . \\
& { }^{3} \text { Ibid., } 35 .
\end{aligned}
$$


to be five conditions necessary for dialogue. ${ }^{1}$ First, he suggests, that the approach to dialogue should be on the basis of a "mutual sharing of religious convictions. . . ." The second is that each participant in the dialogue should have a personal conviction concerning his or her faith. Moreover, he or she should not enter into the encounter with proselytizing goals in view, but with a desire to enrich his or her own faith and that of the other participant or participants. Third, Swearer states that there should be a rethinking of definitions. The basis should be on subjective faith and personal religious experiences rather than historical religious traditions. This does not prevent a religion from laying claims to being absolute, once it respects the similar claims held by other religions. Fourth, Swearer considers "truth as relationship" which is regarded as residing in Jesus who is beyond any one religion's confines. Finally, he believes that the incarnation makes it an imperative for Christians to participate in inter-religious dialogue.

His concept of incarnation is put thus:

In the incarnation the divine identifies with all aspects of human life. Ultimate truth particularizes itself in concrete form not to become limited but to confront man face-toface. Similarly those who would share the Christian gospel must enter into the idiom of particular situations, as did the apostle Paul,

${ }^{1}$ Ibid. , 40-51. 
who confessed to the corinthians, 'I have
become all things to all men. . . .' Apart from these conditions, Swearer concludes that dialogue should begin on the grounds of common interest where people relate as persons rather than as religions.

Schebera ${ }^{2}$ also reflects on Christian/nonChristian dialogue. The major part of his book is an evaluation of Robert $C$. Zaehner's approach to interreligious dialogue. Zaehner advances the argument that there are two points of view relative to the dialogical discussion. There is the "phenomenological point of view" and the "theology of religion point of view." 3 Though he acknowledges the numerous differences between religions, he hastens on to stress that a more positive approach should be adapted in dialogue. There, participants should manifest respect for each other and recognize the mutual benefit and growth that can accrue as a result of the dialogical engagement.

Zaehner is cited as having taken the position that the incarnated Jesus and the extension of Himself in His church is the only unifying element among religions.

'Ibid., 49.

${ }^{2}$ Richard L. Schebera, Christian/Non-Christian Dialogue (4710 Auth Place, S.E., Washington, D.C.: University Press of America, 1978).

${ }^{3}$ Ibid. , 5 . 
This is due to the fact that christ is unique and He possesses the unifying potential in reconciling all persons to God and to one another. Therefore, Christ fulfills humanity's quest for unity.

Schebera, however, sees problems with Zaehner's approach to dialogue. In the first place, it suggests a strong Christian-biased position (relative to other religions). Then, there are conceptual problems with Jesus and His incarnation, because He may be perceived differently by other religions. Schebera opposes claims to exclusive revelation and further suggests that religious pluralism may even be a divine design. For God takes culture, history, and the location where redemption may take place into consideration. Basically, what Schebera pleads for in dialogue is an openness that will allow Christians not to be exclusivistic about revelation and monopolistic about Jesus and His salvific methodology, but flexible.

stowe $^{1}$ who discuss dialogue only briefly in his book has observed certain positions that are taken relative to other religions. These are similar to those mentioned by Swearer. The first is the "closed-mind position." ${ }^{2}$ The proponents of this position advocate

${ }^{1}$ David M. Stowe, When Faith Meets Faith (New York: Friendship Press, 1967).

$$
\text { 'Ibid., } 164 \text {. }
$$


that they, and only they, are right, consequently, all others are wrong. However, when the different faiths or religions interact, the available evidence suggests some similarities which probably are being presented in different ways. Therefore, this position, according to stowe, appears to be simplistic and, at times, absurd. The "Open-minded attitude" ${ }^{1}$ is his second position. It is quite opposite to the first, for it suggests that all religions are equally right because of evident similarities. However, stowe proposes that

we must never assume that relative similarities in ethical principles in various cultures means genuine similarity in corresponding religions. Faith with similar moral teachings may be far apart in their teaching about the meaning of the world and of human experience with it. ${ }^{2}$

There is then a third, the "syncretistic approach." 3 The proponents believe that by abandoning all the negative elements in each religion and combining all the positive elements, there can be formed one universal religion that is better than all. Stowe, however, argues against such a possibility because religions are not so compartmentalized as to allow for such separation of their components.

\footnotetext{
'Ibid., 165 .

${ }^{2}$ Ibid., 169

${ }^{3}$ Ibid.
} 
The fourth position, "Critical commitment and open mind,"1 recognizes value wherever it appears, "but holds all faiths, including one's own, is under [the] judgement of Christ" ${ }^{2}$ who may be revealed in different ways to different people in different times. "The truth spoken and lived by Jesus" ${ }^{3}$ is used as the standard by which all teaching and activities are judged. Stowe subsequently suggests that there are three fundamental steps which are appropriate for the advocates of the last position and any one engaging in Christian/non-Christian dialogue.

He must: understand his own faith, understand other faiths so that he can appreciate their values as well as their defects; be ready to share his own faith with others.

Therefore, in evaluating the truth of any religion including Christianity, it is important to determine whether the attitudes, practices, and concepts which are manifested are consistent with the "truth spoken and lived by Jesus Christ."

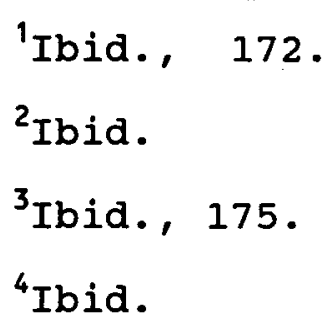


M. Dhavamony, ' in his work, suggests that both Christianity and Hinduism lay claim to universalism and holistic involvement and participation of their respective adherents. He also argues in favor of what he calls "radical unity" between them both. To support his point, he cites Frederich Heiler who suggests that both these religions meet at their conceptualization of the transcendent who is immanent in humanity. Heiler continues by indicating that for man reality is realized through attaining high moral ideals while ultimate reality in the divine is manifested in love both to men and in men. In addition, both religions claim to approach God through spiritual disciplines and sacrifices.

Love is the one principle that unites all men and is the highest avenue to God. Though these principles are expressed doctrinally and religiously different, there is a conceptual commonality of these principles among all higher religions.

\section{Dhavamony then discusses the "radical}

differences between Christianity and Hinduism." ${ }^{3}$ Here he cites R. C. Zaehner who expresses the view that all religions meet together at the end. The only commonality

'M. Dhavamony, "Dialogue with Hinduism," in Evangelization, Dialogue and Development, ed. M. Dhavamony (Rome: Universita Gregoriana Editrice, 1972), 263-276.

$$
\begin{aligned}
& { }^{2} \text { Ibid., } 263 . \\
& { }^{3} \text { Ibid., } 265 .
\end{aligned}
$$


they posses is that they provide an avenue of release for men. Dhavamony declares that the religions are incompatible. This is expressed in the fact that conceptually they differ substantially in terms of the incarnation, creation, divine transcendence, history, and divine intervention. He further suggests that despite their differences, Hinduism and christianity can find a place for meeting. This is at the "Transcendent Horizon, " ${ }^{1}$ which is explained by indicating that,

the meeting between Hinduism and Christianity takes place at the level of the unthematic religious experience in as far as it implies a necessary reference to the transcendence, the absolute God, which is the ground of everything.

In spite of their doctrinal differences, Dhavamony recognizes that both religions meet at the level of love, which is a gift from God. This love focusses on the supreme and manifests itself in activities of spiritual disciplines. He then explains,

This is the theological horizon in which the meeting of the two religions can take place. I call this universalist theological life, for it is common to all religious people who respond to God's gift of his love. The knowledge that results from God's gift of his love constitutes the universalist faith...

\footnotetext{
'Ibid., 266.

'Ibid., 267.

İIbid. , 275.
} 
This common theological life is manifested objectively in different ways and, as a result, there are religious and doctrinal differences. In spite of that, they are all based on love which is common to both. Therefore, on this common premise dialogue may begin.

Ted Peters, ${ }^{1}$ as a Christian, actually participated in interreligious dialogue with Buddhists and Hindus. He is convinced of its importance. He also underscores that there are three positions taken relative to dialogue. These are similar to those mentioned by previous authors. He lists these positions as Confessional Exclusivism, Supra Confessionalism, and Confessional Universalism. Peters subscribes to the third position, which

regards its claims as ultimate $\ldots$ and believes that there is more truth to be learned and that dialogue has the potential of expanding our understanding.

In conclusion, he pleads for subjective participation in dialogue and enough time to allow for a thorough evaluation and sharing by all participants, if dialogue is to be a success.

Christian/non-Christian dialogue aims at generating respect, trust, and common sharing of

1Ted Peters, "A Christian Theology of Interreligious Dialogue," The Christian Century 103, no. 30 (July-December 1986): 883-885.

$$
{ }^{2} \text { Ibid., } 884 \text {. }
$$


subjective faith, not by the religions, but by individual participants of the religions represented in dialogue. There may be a resulting adjustment to the beliefs of the participants because of an encounter with new information. However, the desire to have one change his or her religion or proselytizing are not generally the goals of this kind of dialogue.

\section{Conclusion}

From the review thus far, it seems apparent that contextualization, indigenization, and Christian/nonChristian dialogue are more concerned with establishing relationship, rather than evangelizing from the perspective of Matt 28: 18-20. There appears to be no burden to lead those of other religions and culture to make the radical changes in their lives that deciding for Jesus necessitates. For example, those people who accepted Christ from some communities of Asia Minor like Antioch and Cilicia had to give up fornication, eating of meats offered to idols, eating of blood, and things strangled which were culturally and religiously acceptable (Acts 15: 22-35). When those of Ephesus accepted Jesus Christ as Savior and Lord, they not only gave up their heathen practices but the community's culture and economy were even affected (Acts 19: 1-27).

For the purpose of this study, culture should be percieved as systems and structures that human beings 
created in order live in their particular context. These systems and structures are not sinful in themselves, but they assume the sinful or righteous qualities of those who create them. The gospel which is acultural seeks to change human beings and they in turn appropriately change their culture.

Indigenization which has to do with adapting the religious structures and systems appropriately to those who have received the gospel, are implied in the term contextualization.

Contextualization should be considered as a process where the evangelist/missionary, the method of presenting the gospel, the wrapping in which the gospel is couched, and the resulting church are so adapted that they become congenial with elements of the culture into which the gospel is introduced, without in anyway compromising the intent and the spirit of the gospel. In other words the gospel should remain unchanged though it should change the negative cultural elements of those who accept it.

Dialogue should be seen as an initial aspect of evangelism. It facilitates the mutual sharing of subjective faith on a personal level and the establishing of mutual trust and respect between the participants. These allow for the implimentation of other aspects of the evangelization process. 
Consequently, the principles of contextualization, indigenization, and Christian/nonChristian dialogue could be instructive in assisting to formulate a strategy for evangelizing the Hindus in Trinidad. These principles should not be viewed as evangelistic methods since their ultimate goals are not the same.

\section{Evangelism among Hindus}

\section{Health Seminar}

Some programs which were implemented and which partook of some of elements of the stategy for evangelizing Hindus that will be proposed in the next chapter are considered here. Though they did not go far enough in terms of using more effectively the principles of gospel and culture, contextualization, and dialogue, and therefore, manifest some weeknesses, they nevertheless constitute a move in the right direction.

\section{Haren Sthalekar conducted an evangelistic} program among Gujarati Hindus in Nairobi, Kenya, with the intent of leading them to make a decision in favor of Jesus. ${ }^{1}$ The aspect of evangelism that he used was the Health Seminar. A survey of the targeted area revealed that a health emphasis was most relevant to the felt needs of the Hindus in that community. is about.

'This is what sthalekar's entire project report 
Though he encountered obstacles and hindrances, Sthalekar was able to report some success that resulted from his mission. For after only two years work in what had previously been an unentered territory by the seventhday Adventist church, Sthalekar was able to directly influence about one-half of the Asian population. ${ }^{1}$ They became informed of the existence of the seventh-day Adventist church as a genuine Christian denomination that was interested in the welfare of all people, including the Asians. These same people were then acquainted with the philosophy and some of the fundamental principles of the Adventist church. They actually participated in and particularly, benefited from the health programs which included health screening, nutrition, stress management, stop smoking, and mental health. Sthalekar notes that though he was unable to give specific figures on actual attendance at the various programs he had conducted, as an indication of success he mentions that

Many of these gave up smoking and other harmful habits and acknowledged the benefits they received. For example, the managing director of one of the largest industries--steel Billet Limited--phoned to tell me he was following some of the health principles and had benefited to the extent that instead of being admitted to the hospital for treatment due to nervous strain, he was back to normal work.?

$$
\begin{aligned}
& \text { 1'Ibid., } 101 . \\
& { }^{2} \text { Ibid. }
\end{aligned}
$$


In addition to the health emphasis, the Asians were also introduced to the practical gospel of Jesus Christ, "including the beliefs in prayer, sabbath keeping, etc." Despite the success that was experienced, sthalekar has suggested that a restructuring of health seminars, the establishing of a multi-purpose hall for health, recreation, and other activities of local interest, and the establishing of more advanced academic institutions could enhance further success.

Sthalekar attempted contextualization in the sense that he did not use the evangelistic methods that were being used in other parts of Kenya. Though his approach seemed relevant to the Hindus and other Asians, he might have spent more time using the principles of Christian \non-Christian dialogue in order to establish a better relationship with the Hindus. Then he might have contextualized his method of presentation not only to deal with some of the concerns of the Hindu people but in a way that was more in keeping with their way of life. For the Hindus, health is an integral part of religion, therefore it may not have been used as an independent entity. Furthermore, the presentation may have been conducted in a family or home setting with the necessary decorations and an appropriate meal if it was to be a formal meeting. Sthalekar, being originally of Tamil Hindu origin, could have used the native language to great advantage. 
Public Evangelistic Crusade

John willmott conducted a public evangelistic crusade project in the predominantly Hindu city of Poona, India. ${ }^{1}$ Prior to the crusade, regular contacts were made between the Hindus and other people in the community and the members of the Seventh-day Adventist church.

As a direct preparation procedure for the crusade, a demographic study was done and a targeted area was identified. Surveys in this particular area determined the felt needs of the residents. The members of the church were trained and organized to minister to the needs of the people of the selected community. As a result of this felt-needs ministry, a little boy who was ill was cared for and as a result the entire family was baptized. 2

willmott made a deliberate effort to contextualize his crusade. In doing so, he conducted the meetings in a school hall that was centrally located. For the first time, the preaching was in Tamil, a predominantly used language of the area. In addition, to meet the interest of those who attended the meeting, each night a health lecture and lively community singing preceded the preaching.

'John Willmott, "Urban Evangelism in India: An Evangelistic Project Conducted in the City of Poona," (D.Min. project report, Andrews University, 1981).

$$
{ }^{2} \text { Ibid., } 62 \text {. }
$$


The average attendance was about 160 persons, though only a minority were Hindus. The evangelist noted that Hindus do not like to attend public Christian meetings and, if they do so, they prefer to remain unidentified. When the series of meetings came to a close fifty-seven persons were baptized and a new church was started. Willmott recommends that this type of evangelism should be encouraged and aggressively pursued so as to expose the vast Hindu population to the gospel of Jesus Christ.

The fact that willmott noted--that Hindus do not like to attend public Christian meetings--and he encourages the conducting of similar meetings, confirms my initial statement that these programs did not go for enough. Though the school room that he used was a central setting and removed from the church, better contextualization would have suggested that since the majority of Hindu religious activities are conducted in the homes he might conducted his meeting in harmony with this trend. In addition, willmott should be commended for using Tamil language, but the outline of his program too closely resembles that used in North America and the Caribbean. It needed to be more reflective of Hindu worship forms. 
Christian Ashrams

Christian ashrams has been an attempt at institutional indigenization. ${ }^{1}$ Richard W. Taylor ${ }^{2}$ states that Ashrams in India grew out of the "Bengal

Renaissance." Christians in India who had been involved in missions were finding the use of Christian Ashrams advantageous to the spread of the gospel in their country. Hence, at the National Missionary Society of North India, K. T. Paul, the then General Secretary, - . suggested that the NMS was expected to develop methods distinctly indigenous. . . For this purpose he suggested a Christian Ashram which will attract the most spiritual of our christian youths and train them in three ways: (a) affording evangelistic equipment to meet the best exponents of non-christian religions on their own ground; (b) giving sufficient knowledge of medicine so as to alleviate suffering by nursing and to treat all ordinary diseases; (c) providing the training of an artisan for example either in carpentry or weaving so as to make self-support possible to every worker. ${ }^{3}$

A Christian Ashram established in 1921 at Tirupattur by Protestants, Drs. S. Jesudason and E. Forrester-Palon, was evidence of an appropriate response. In that Ashram,

${ }^{1}$ For purposes here, a Christian ashram is a religious commune or boarding institution where the residents develop certain spiritual disciplines and skills for ministry to others.

${ }^{2}$ Richard w. Taylor, "Christian Ashrams as a Style of Mission in India," International Review of Missions 68, no. 271 (July 1979): 281-293.

${ }^{3}$ Ibid. , 283. 
Home spun hand loom cloth was worn which in addition to being inexpensive and simple, had a strong nationalist political implication. Only vegetarian food was served.'

There the residents did almost all the household work which fitted into the tight daily schedule of work, study, and worship. Their ministry to the community was mainly in the areas of medical care, educational and agricultural development, and evangelism.

The Roman Catholic Church also has been involved in ministry and mission through Ashrams. These were three more successful ones in terms of the number of participants and the effectiveness of the programs they conducted. The Christa Panthi Sangh Ashram in Sihora was different from the standard ashrams, in the sense that both male and female participants were present. Some of these were part-time residents. The residents in this Ashram were involved in "worship, evangelism and rural social and economic work." ${ }^{2}$

The Christiya Bandha Kulan Ashram, located near Satna, and the Sachhidanand Ashram, at Narsinghpur, have both proven beneficial to the work of mission and the development of the local church.

Taylor indicates some specific areas of success Ashrams have accomplished generally.

$$
\begin{aligned}
& { }^{1} \text { Ibid., } 284 . \\
& { }^{2} \text { Ibid., } 289 .
\end{aligned}
$$


A major contribution in Indian Christian theology has come from the ashrams. Out of twenty individuals treated either biographically or autobiographically in two series of books published by the CISRS that dealt primarily with Indian Christian theology, twelve have had intimate connection with ashrams. . . And half of the remaining eight have been important encouragers of ashrams and participants in some of their programs.'

Ashrams have contributed significantly to Christian art, for out of the six most prominent artists considered by Taylor, four were guided and substantially influenced by the Ashrams. He also suggests that Ashrams have made significant contributions to the indigenization of church architecture and the contextualization of liturgy in India.

It ought to be noted that these ashrams were not designed with that aspect of evangelism that is concerned with winning new converts to Christianity. Their emphasis was on conservation of those won by other means and enabling them to minister to others. The fact that these met with some success is encouraging. The ashram format can be used, but emphasis should be placed on training the participants to work for the salvation of Hindus. Those who would be converted can become members of an ashram and be trained for evangelism also. In this sense the ashram can become an evangelistic tool.

$$
\text { 'Ibid., } 293 .
$$


Christian Film

The film Karunamayudu ["Man of Mercy"]" is a two-hour movie on the life of Christ. According to Gilman, this movie was

- . produced in India with all-Indian caste and initially released in Telugu, one of India's 14 major languages. 2

It was culturally sensitive and made quite an impression on those who saw it, as it was being shown

evangelistically. Gilman notes that the film was being shown free in different communities to over 200,000 persons each month. The response was overwhelming.

Many sobbed aloud during the crucifixion. The response to the invitation was equally amazing, as hundreds raised their hands, indicating a desire to follow christ. And dozens were baptized in nearby rivers the following day. People of every age and walk on life, children, moms, dads, businessmen, criminalş, prostitutes, even a Hindu priest."

This impressive success has lead Billy Graham's associate evangelist for Asia, Robert Cunville, who is an Indian, to believe that a great evangelistic harvest will follow the showing of the film. In addition, an Indian missionary remarked that "the film will make a greater contribution to missions than all other ministries combined. "4

'John Gilman, "Karunamayudu," Christian Life 46 $(1984-1985): 70-74$.

${ }^{2}$ Ibid., 73 .

${ }^{3}$ Ibid., 74 .

${ }^{4}$ Ibid. 
Working through Head of Family

In the Udaiyar community, in Tamil Nadu, a man

who had been claiming to be God was teaching from the New Testament. He had raised up quite a following during his lifetime. But the situation created such a surprise and scandal that it prompted a government investigation and the organization was disbanded. Some time later, some missionaries visited the same community and worked with the head of a family who belonged to the disbanded organization. After a few months, the man accepted Jesus as savior. Eventually, his family members believed and were baptized.' This method of evangelism is an example at contextualization.

\section{Contextualized Gospel Meeting}

A series of meetings were conducted at Bonase Village in south Trinidad. ${ }^{2}$ Because that community was predominantly Hindu, the meetings were conducted at the home of a practicing Hindu. The meetings were held for nine consecutive nights, after the pattern of a Hindu Bhaagwat--a family devotional meeting when readings from the Bhagavad Gita are done, pujas are performed to various gods, flags are hoisted, and the those who attend are fed.

"The Consultation on World Evangelization MiniConsultation on Reaching Hindus," in The Thailand Report on Hindus (Wheaton, Illinois: Lausanne Committee for World Evangelization, 1980), 13.

\footnotetext{
${ }^{2}$ Personal experience.
} 
For these meetings which were called Yeshu Cataar ["Life of Christ"], the accommodations were decorated with ribbons and buntings. A raised platform was provided for the musicians and the singers who performed in a squatting posture. There was no pulpit. All who participated in the program were of East Indian descent.

About thirty minutes before each meeting started, Hindi Christian music was played over the public address system. To officially start each meeting, the people were greeted in $\mathrm{Hindi}$ and taught to respond in a similar manner. About fifteen minutes were devoted to community singing and special selections by the official singers who were accompanied by East Indian instruments. The songs--Bhajans--were all sung in Hindi. However, the pronunciations and the English translations were circulated in printed form to all who attended, because though the majority of Hindus love to listen to Hindi and choose to do so regularly, they hardly speak or understand it. The main feature each night was a slide show and recorded presentation of a portion of the life of Christ. This, too, was in Hindi, but was translated into English as it proceeded. The meetings concluded with the 
serving of coromar and a type of prashaad' (though it was not offered as a sacrifice). On the final night, to conclude the meeting, a full Hindu meal was served in Hindu style.

This meeting seem to have had the best attendance of all similar meetings conducted in that community. The majority who attended indicated that they enjoyed what was done. A Christian church leader of East Indian descent whose church is in a predominantly Hindu community asked to have a similar meeting conducted in his community. In addition, at least one person who attended began attending the Seventh-day Adventist Church.

All of the evangelistic methods reviewed here are different. But it should be noted that the situations are all distinctive. Likewise, the results varied greatly. While this represents a variety of methods in evangelism among Hindus which may be needed, an overall strategy which informs these methods is needed for greater productivity.

'Vidyarthi, 103. Prashaad' is the sacred food of the Lord. It is comprised of 'Mohanbhoag' [a lusty preparation of flour, ghee, milk, raisins, and sugar], sweet rice, fruits, milk, coconut, sweets, etc. 


\section{Conclusion}

This review reveals that Hindus see no

difference between their religious and secular life.

All of life and life's activities are religious.

Christianity, however, differentiates between the sacred and the secular. Therefore, in light of the fact, as has been mentioned earlier (see above p. 159), according to the biblical standard some aspects of culture are to be kept, some are to be modified, and others are to be replaced. The evangelist/missinoary to the Hindu needs to retain some aspects of Hinduism, reform some others, and replace the remainder. In assuming a new religion-Christianity--Hindus should be led to assume a new life style with new values. The Bible has to be the basic guide in deciding.

It appears evident that among authors there is a divergence in how they perceive the understanding, meaning, and the scope of indigenization and its relationship to contextualization. Nevertheless, it is not surprising that all seem convinced that there is need for adapting the wrapping in which the gospel is offered and the methods of communicating it. This creates the need for the acceptance of diversity but with the essence of the gospel unchanged. However, the fact that contextualization is biblically informed and there are paradigms especially in the ministry of the apostle Paul (see above 
pp. 48-50 and 60-64), the necessary guidelines are provided to ensure that Christianity can thrive everywhere in this world.

From the study of inter-religious dialogue, the burden of the authors cited seems to be with establishing a cordial and acceptable relationship among religions and the participants in inter-religious dialogue. They are also concerned with the sharing of subjective faith, mutual acceptance, and the adjusting of one's belief, if necessary, due to exposure to new data. Apart from the position taken by David M. Stowe, who does not deal with dialogue per se, proselytizing is not to enter into dialogue. Therefore, anyone who desires to lead Hindus to Christ has to make some adjustment to dialogue or, at best, use it as a preliminary step in the evangelistic process.

The evangelistic methods which have been used are all different and have produced varying results. However, because they did not go far enough, the proposed strategy attempts to create programs that would better reflect the principles of gospel and culture, contextualization and Christian/non-Christian dialogue. These will maintain faithfulness to the intent and spirit of the Bible, as disciples are being made of Hindus in Trinidad. 
PART II

STRATEGY OF EVANGELISM AMONG THE HINDUS IN THE REPUBLIC OF TRINIDAD AND TOBAGO 
CHAPTER V

\section{RECOMMENDED STRATEGY}

\section{Introduction}

This chapter attempts to address a way whereby Hindus in Trinidad may be evangelized. The suggestions proposed here are informed by the mandate of the gospel commission, the theology of evangelism that has previously been developed, the peculiar challenges posed by Hinduism, in general, and in Trinidad in particular, and data suggested by selected literature.

In the first section, a proposed strategy is defined and outlined, and major aspects are developed to enhance clarity. The second section concerns itself with possible methods that may operate within the circumference determined by the proposed strategy. The third section indicates how the strategy may be implemented by the church, and the concluding section provides some guidelines that should be observed when this strategy is being set in operation. 


\section{Strategy}

It was established above that a strategy is a comprehensive plan of approach for accomplishing a particular goal or set of goals. Therefore, in order to evangelize the Hindus in Trinidad, it is imperative first to develop a strategy that is appropriate to that situation. Such a strategy should incorporate some basic principles which would inform the methods and persons participating in the evangelization process.

These principles ought to include the following:

1. Principles informed by a theology of evangelism a. To make disciples of all Hindus possible through teaching and baptizing

b. To use a people-movement approach to evangelism from the perspective of dealing with people who have little or no knowledge of the gospel and will have to change their religion

$$
\begin{aligned}
& \text { c. See 2: b } \\
& \text { d. See 3:a }
\end{aligned}
$$

2. Principles informed by the peculiar challenges of Hinduism

a. To use a people-movement approach to evangelism because of the cohesiveness that can exist in the varied forms of castes, communities, and families in Hinduism (The religious implications rooted in the Hindu family is another reason for this approach.) 
b. To move from the less complicated to the more complicated. Evangelistic work should begin with those former Hindus who are Christians of other denominations. Then work should be done with Hindus who have close family and friends who are seventh-day Adventists and with whom they have an intimate, trusting relationship. Finally work should be done with those who are staunch, practicing Hindus.

c. To explore issues and themes with which Hindus are conversant, and which relate to and provide solutions to some of the fears and problems that may be peculiar to them. These may include creation, the deities, salvation, the nature of man, death, successful survival in this world, and the hereafter. This should be the primary focus of the gospel. It should be noted here that these do not mean the same to Hindus as they mean to Christians.

d. To develop an approach that is informed by a proper knowledge and understanding of the needs of the Hindus being approached.

3. Principles informed by selected literature a. To have crystallization of and a positive attitude towards God's involvement in cultures realized b. To maintain positive attitude towards Hindus who should be recognized both as religious and equal 
persons. Hinduism should be recognized as a bona fide religion from a sociological point of view.

c. In an attempt at contextualization of personnel, the modus operandi should be to encourage people of East Indian descent to labor with Hindus in the interest of their salvation

d. To communicate elements that are familiar to Hindus and to use to the fullest peculiar linguistic idiosyncrasies. For example, the illustrations employed to explain biblical truths and themes could be drawn from Hindu literature and traditions--for example, the experience of Krishna and the story of the "Mud pie and the dry leaf."

e. To use methods that allow for replacing what the Christian perspective sees as "religious" elements in Hinduism, while at the same time showing respect and sympathy for the "cultural" elements.

f. To use dialogue as an opening wedge for evangelization.

g. To contextualize the method of presenting the gospel, the venues that are used for evangelism and the liturgy, architecture, and general operation of the church that may result from such efforts. 


\section{Attitude Towards cultures}

(A further clarification of point $3 a$ )

It was established above that in Hinduism there is no difference between culture and religion. It is therefore of paramount importance that those in Trinidad who are evangelizing Hindus clarify in their own minds their attitude towards culture. They should not fail to flesh out conceptually the role of God or His level of involvement in cultures. The result of working through these processes will significantly influence how one relates to these people, what programs will be planned, and how they will be implemented.

Each prospective evangelist needs to address the following pertinent questions. Did God create one culture or cultures? If He created one culture, are other cultures a natural outgrowth of the one, and were they designed to meet the needs of different situations as human beings replenished the earth? Are these natural outgrowths under His jurisdiction and administration? on the other hand, are cultures the creation of sinful human beings in their act of rebellion against God?

If God created cultures, are they still under His control or has He abandoned them because of their inherent sinfulness? Are they really sinful? Should they be under His control, then can it be assumed that He is involved with them and may be using them? on the contrary, if $\mathrm{He}$ is not in control, then is He trying to 
reform cultures as He saves man in order to bring them closer to the divine likeness? Is He doing so with all cultures or only some? If some, which ones?

If God did not create any culture, then may we assume that human beings did, either directly or indirectly? Assuming this to be so, what is God's relationship to these human innovations? Does He reject them completely or does He use the positive elements in them or seek to reform them? Are all cultures, therefore, equal in His sight?

Are cultures good or bad; are some good while others are bad; and which fall into what category? on the other hand, are cultures amoral in the sense that they are neither good nor bad?

An examination of the creation account (Gen 1: 1-31) does not seem to suggest that God created culture as He did the stars, the animals, and the plants. Instead, God created the human family perfect and in His own image, and placed them in a particular context--the garden of Eden-- with particular instructions to further develop their environment, expand the family, and occupy the earth with dominion over God's creation (Gen 1: 28; 2: 15, 17, $19,20)$

In addition, God endowed humanity with capacities to develop those systems and structures that 
were necessary for them to live orderly lives on earth. ${ }^{1}$ The structures and systems that humanity developed constitutes culture. As long as mankind remained submissive and obedient to God, the components of culture would have remained in harmony with the divine plan. Therefore, from this pers-pective, cultures were good and could have been used by God in His divine plan.

Subsequently, the human family sinned. They rebelled against God. In their post lapsarian state, all structures and systems that were developed or modified became tainted with the effects of the sinfulness of humanity ${ }^{2}$ and, consequently, participated in a system of rebellion against God. Hence, cultures were conditioned in rebellion and corrupted contrary to the divine plan. By the second millennium after creation, humanity and its cultures were in such open rebellion against God (Gen 6: 5, 11-13) that He repented that He had made humanity and was left with no other alternative but to destroy humanity along with the systems and structures that they had developed (Gen 6: 12-13). They were so far removed from the divine plan in intent and outlook that God was no longer able to use them in His purpose.

1Ellen G. White, Patriarchs and Prophets (Mountain View, California: Pacific Press Publishing Association, 1913), 44-51.

$$
\text { 'Ibid., 63, 90-96. }
$$


Noah and his family only were saved as an act of grace because they trusted in God and endeavoured to be obedient and submissive to His will. After the flood, to this family the original command of Gen 1: 28 was reiterated in Gen 9: 1, 7; they were to be fruitful and multiply and replenish the earth. Here again humanity was given another opportunity to develop systems and structures that were essential for the successful occupation of the earth. These were to be in harmony with the divine plan.

Again this failed because humanity chose to persue a path contrary to God's revealed will. Consequently, God called out Abram and his family and isolated them in a foreign land in order to develop systems and structures through which the world would be exposed to the will of God and His saving grace Gen 12 . This basic principle of God selecting a particular people who are submissive to His will and who trust in Him to accomplish His purpose for all humanity has been constantly repeated historically, when the rebellion of humanity has reached the point where God was no longer willing to use them. This scenario has evidently in part given rise to the remnant theology that is a reoccurring phenomenon in eschatology. 
In the light of the foregoing discussion, the proponents of cultural relativism stand in need of correction since cultural relativism advocates

that there many ways to God, many cultures and many standards of right and wrong. Any attempt to persuade men of other cultures to your way of thinking is cultural imperialism. To the cultural relativism, Christian mission are impertinent invasion of ethnic units whose members are happy and satisfied in their own customs and beliefs. If men care to become Christians, they should bring their own customs with them.

In the first place there is only one way to God; John 14: 6 declares that Jesus is the only way. Furthermore, Acts 4: 12 states that salvation can be had only in the name of Jesus. The only standard of right and wrong which is the law of God. Second, to persuade people to a way of thinking when that way of thinking is more in harmony with the will of God is not necessarily cultural imperialism when the better way is clearly placed before others and they can see it and make a personal choice in favor of it. once this thinking is not imposed, then it may not be cultural imperialism. Third, people who are in open rebellion against God with cultures that support that rebellion cannnot be comfortable, happy, and satisfied. The Bible is replete with statements indicating that the wicked and disobedient are plagued with fear, guilt, discouragement, hopelessness, and doubt. Finally, if 
people choose to become Christians then the very name implies that they have to assume a new life style with new customs that are progressing to the ideal that God has for His children. 2 Cor 5: 17 clearly states that if a man is in christ he is a new creation.

Furthermore, it ought to be mentioned that when people and their cultures are not fully committed to truth as it is revealed in christ, whatever positive elements they may possess, they are likely to condone evil practices like the oppression and discrimination of certain people based on color of skin, race, sex, place of birth, and ancestral line.

Because all persons are sinners, Rene Padilla argues that

No culture completely fulfills the purpose of God; in all cultures there are negative elements, unfavorable to the understanding of the Gospel. For this reason, the Gospel never becomes completely incarnate in any one particular culture. The only culture that can be considered absolute is the culture of heaven where sin is absent. Nevertheless, those who individually or collectively are aspiring to that ideal by God's grace would of necessity create good and better, though not perfect cultures.

Those cultures that may not be classified as Christian cultures, have not been abandoned as yet by God

${ }^{1}$ Rene Padilla, "The Contextualization of the Gospel," in Readings in Dynamic Indigeneity (Pasadena, California: William Carey Library, 1979), 291. 
just as the people have not been abandoned but are the objects of His salvific plan. As He attempts to restore people to His own image and likeness; similarly, He is restoring cultures to the heavenly model.

In conclusion, God did not create cultures, but people have been creating them. Though cultures may not be necessarily classified as sinful, on the one hand, when people who are in rebellion against God create cultures, they tend to include systems and structures which support the practices and lifestyles of rebellion. Those cultures created by people who are submissive and obedient to the revealed will of God tend to include systems and structures which support a lifestyle in keeping with the will of God.

On the other hand, in neither case is the culture necessarily wholly evil or wholly good. NonChristian cultures may include systems and structures designed to support a lifestyle that is conditioned to the enviroment in which the people live, or they may be designed to support a lifestyle that is not wholly opposed to Christian principles. In such cases these cultures may not be seen as evil. By the same token, when Christian cultures include systems and structures that support practices not in keeping with Christian ideals, they must be seen as evil. 
Just as God does not reject people, He does not reject cultures except where they persistently and knowingly rebel against God and end in destruction. As an act of grace, God condescends to save, to restore, and to reform people, and use them in His service. The same happens with culture which is an integral part of humanity.

Attitude Towards Hindus

(A further clarification on point $3 \mathrm{~b}$ )

Those who desire to evangelize Hindus must question their attitude towards Hindus both as individuals and as a community. Though they may be recognized as a religious people endeavoring to serve God based on their limited revelation, they are nevertheless non-Christians and need to be evangelized because the path they are pursuing leads away from God.

Cultural relativists argue that there are many ways to God and many standards of right and wrong. As far as Hinduism is concerned, Panikkar advocates that

Christ is already there in Hinduism in so far as Hinduism is a true religion. Christ is already at work in any Hindu prayers as far as it is really prayer: Christ is behind any form of worship, in as much as it's adoration made to God. . . . He is already there, [in Hinduism] as $\mathrm{He}$ is also with the poor and the thirsty and the prisoner and the persecuted.

\footnotetext{
${ }^{1}$ Raymond Panikkar, "The Unknown Christ of Hinduism," in Christianity and other Religions, ed. John Hick and Brian Hebblethwaite (Glasgow: William collins Sons \& Co, 1980), 138.
} 
It should be observed that Hinduism can only be classified as true religion not in the sense that it possesses "truth" but only as a sociological institution. It facilitates the worship and service of the supernatural and possess a system of institutionalized beliefs, practices, and attitudes. In addition, God is not working in Hinduism as a religion per se but only in the sense as it is a part of the world which is the object of God's salvific acts. The Hindu person cannot find salvation in Hinduism because it does not offer christ, the only means of salvation. Nevertheless, because of God's saving grace, the Hindu may be saved in spite of Hinduism.

The evangelists however should, relate to the Hindus as brothers and sisters from the perspective of the universal fatherhood of God. As was discussed earlier, true Christians have positively responded to God's revealed will. Consequently, their lives are lived more in harmony with the divine plan; therefore, from this perspective Christianity leads along a path of life that is God-ward, while Hinduism leads away from God along a path of death and destruction.

with loving respect, humility, and patience, the Christians from their privileged position of grace should approach the Hindus to tactfully and gently lead them to Christ the Savior of humanity. To the end that those who accept Him may have the privilege of living a life of 
fulfillment here and the fulness of life in the world to come.

People Movement Approach

(A further clarification on points $1 \mathrm{~b}$ and $2 \mathrm{~b}$ )

Hindus in the Hindu communities of Trinidad are extremely clannish. In addition, families tend to be extended or to exist in an accommodated form called the kinship group. In any of these situations, the interest and the well-being of the group takes precedence over that of the individual. It is also a commonly accepted theory that the success and the welfare of the individual resides in his or her remaining loyal to the group.

Consequently, any attempt to evangelize Hindus should place more and primary emphasis on the peoplemovement approach rather than on evangelizing individuals in isolation, which should be the last resort. Before defining "people movement," it may be helpful to first explain who may be considered a "people." This term from the perspective of evangelism means more than a sociological entity or group. The group which may be of varying sizes is comprised of people who share a number of things in common which differentiate them from other groups in their nation, city, or even neighborhood. The features of identity may include

language, religion, ethnicity, residence, occupation, health class, or status, caste, legal situation, or some combination of these. - . They come to see themselves as a people 
and others begin to treat them as distinctive. 1

Furthermore,

What is crucial for the formation of a people is the way in which those characteristics are subjectively given meaning and used to define what it means to be, a part of this group instead of another. ${ }^{2}$

A people-group may be a family as well as a social class and all groups in between which meet the criterion. 3

The people-movement in Christian evangelism, then, is the system whereby the group is led to make a decision for Jesus as one cohesive unit rather than a number of separate individual decisions. ${ }^{4}$ B. V. Subbamma describes a people movement this way.

A people movement involves multi-individual decisions, meaning that many people participate, each making up his own mind after debating with himself and others within his group. Each individual is saved not by going along with the crowd, but by his personal faith which led him to participate in the decision of the group.

The decision of the group becomes binding upon all the members who, because of their loyalty and the cohesiveness

\footnotetext{
${ }^{1}$ Dayton and Fraser, 137.

2'Ibid., 136

${ }^{3}$ Ibid. , 137 .

${ }^{4}$ Donald McGavran, The Bridges of God (New
} York: Friendship Press, 1968), 12-13

${ }^{5}$ B. V. Subbamma, New Patterns for Discipling Hindus (South Pasadena, California: William Carey Library, 1970), 105 . 
of the group, will normally subscribe or are sympathetic to the majority of the group's decision.

The individual in such a position who makes an independent decision in the area of religion is exposed to defeat from two fronts. He or she may be ostracized by the group as a result of his or her decision or be so overwhelmed by the group that his or her new life in Christ becomes so eclipsed that it eventually dies. The process is similar to the body's defence mechanism.

A people deals with an invasion of new ideas or practices in just that fashion. It walls off and walls out the infected individuals. Ostracism is a people's defence against any new thing felt seriously to endanger the community life.

The destabilization caused by such a situation alienates evangelists because they are regarded as enemies and elements of disruption by the family, group, or community. Hence, it becomes very difficult if not impossible at times to further evangelize other members. After careful examination of this phenomenon, McGavran argues that the best solution to such a challenge to evangelism is the people movement. He sees this movement as particularly beneficial for

non-Christian men and women who for the first time are turning to Christian faith. Furthermore, they are turning in a society where to become a christian is held to be betraying one's family and "making another father." Under such circumstances one-by-one

\footnotetext{
${ }^{1}$ McGavran, Bridges of God, 20.
} 
evangelization, while it saves the individual (provided he can stand the persecution and outlast the ostracism), loses the group. All his relatives are hardened against the gospel. The more tightly knit is the homogeneous unit from which converts comes, the more difficult it is for converts to come one by one. If the Great commission is to be carried out and panta ta ethne (peoples) are to be disciples, a mode of evangelization must be used which enables converts to remain in their family and kin groups.

When an individual in such a setting has accepted Christ as Savior and is excited about following Him, it may be considered expedient to encourage that individual in the decision. However, the evangelist should discreetly delay his baptism or public demonstration of the decision while the group of his or her origin is being evangelized. The time invested may prove well spent for both the individual and the group. This system was successfully used by the early church in its evangelization (Acts 10) . Cornelius was not baptized in isolation but his entire household was ministered to and they were all baptized. In Acts 16: 14-15, Lydia was the person initially encountered, but in the end her household was baptized.

\section{Challenges of the Hindu Family}

Among Hindus, the family, kinship, or even community is many times inseparably cohesive. Because of

${ }^{1}$ Donald McGavran, Momentous Decisions in Missions Today (Grand Rapids, Michigan: Baker Book House, 1984), 107. 
the inherent social power structure and the religious implications rooted in the family, the people-movement approach to evangelism may be the most effective. The Hindu family tends to be patriarchal in practice. Though every family or person may not live as one extended family unit, the dominance of the senior male, nevertheless, is respected. He usually has the final say on issues affecting the extended family or a group of closely knit or closely related families, and the members of the family, group, or community normally sympathize with his decisions.

Consequently, in the process of evangelizing a Hindu community, it may be prudent to seek out the dominant male leader or leaders and establish a cordial relationship with them and work with them in the interest of their salvation. If they are favorable, it will be far easier to lead the entire family or commu- nity to accept Jesus as Savior and Lord. In the event they are not so inclined, but other members of their group decide to follow Jesus, the resulting situation could be less explosive.

The Hindu Family and Dharma

Another reason in support of the people-movement approach in the evangelization of Hindus is their eschatological and salvific concepts. This includes their philosophy of dharma, death, salvation, life after death, 
and the end of the world. The undergirding principle is that the positive outcome of all these critical concerns are based on maintaining the cosmic order. All Hindus as they do their assigned dharma actively participate in ordering this cosmic good.

The wife who is usually at home and does the daily devotions at the appropriate times on behalf of the family or enters the shrine at home every morning "offering flowers and cleaning the room, and preparing it for her husband to pay the offering or puja" ${ }^{1}$ is fulfilling her dharma. Similarly, the eldest son is doing the same when he acts as the savior of his father by administering the posthumous rites that assures the soul of the father deliverance from hell.2 Moreover,

By performing his or her dharma each family member ensures the welfare of the family in this world and the next. Therefore, any attempt to disrupt this intimacy and solidarity are met with great resistance and resentment. Ultimate salvation is obtained by staying within the natal family unit or caste, staying away from it is to imperil not only one's own salvation, but that of many others. ${ }^{3}$

These reasons would indicate why frequently there is so much hostility and resistance to the conversion of family members, especially the eldest sons. They, as Christians, could no longer perform the Hindu

\footnotetext{
${ }^{1}$ Chandy, 67 .

${ }^{2}$ Ibid., 68 .

${ }^{3}$ Ibid.
} 
rites, and thereby would imperil the destiny and wellbeing of the rest of the Hindu family, both living and dead. However, if the people-movement approach were adapted and all or the majority of the family or group were converted or were sympathetic to Christian beliefs and values, this problem would be somewhat alleviated.

The Hindu Family and Marriage of Children

It should also be noted that Hindu parents are concerned that their children be married and, moreover, be adequately married. When the children become christians individually, the population of marriage prospects in the Christian community may be small. Parental or peer presure may force the individual to return to the Hindu community to find an adequate mate and that person may never return to the Christian community. However, the people movement has the potential of providing a greater population of marriage prospects. Moreover, the marriage outlook of the family and peers could be somewhat altered because of their acceptance of Christianity. Consequently, they may be more inclined to make adjustments in the qualifications for an adequate marriage prospect.

\section{Conclusion}

When the people movement is employed and the community, family, or kinship group is converted in a 
block, the needed support system for this new way of life is automatically set up and needs only to be trained. Furthermore, the establishment of churches and other socio-cultural-religious changes are less traumatic. Finally, it may be pointed out that the group rather than the individual is better able to withstand the effects of hostility and ostracism.

Whatever methods may be employed to evangelize the Hindus in Trinidad, the primary goal and objective should be to win the family, group, or community all at one time.

To Hindus, for the Holy spirit to convert a person is not objectionable and for the individual and for groups of individuals to have spiritual experience is agreeable; but joining another community is all wrong! Christianization by asking converts to join other social and ethnic groups not only causes much loss to the individual, the family and the community but is bad for the resulting church and prevents further spread of the Christian faith.

Where this fails, in spite of all possible efforts that have been employed, individuals who have decided for Christ have no other choice but take a stand and trust the consequences to God.

Issues of Concern for Hindus

(A further clarification of point 2c)

Hindus are particularly interested in the future and in life after death as it affects them and their

\footnotetext{
${ }^{1}$ Subbamma, 31 .
} 
families. ${ }^{1}$ They are also concerned with the maintenance of the cosmic order where there is constant conflict between the good gods and the evil demons. Consequently, substantial attention should be given to such themes and subjects as creation, salvation, doctrine of man, deities, and eschatology.

In Trinidad, Hindus show particular preference for those aspects of Hinduism that provide immediate rewards and solutions. ${ }^{2}$ Moreover, there has been regular intra-family conflict ${ }^{3}$ and inter-family competition. As the Hindus arrived and settled in Trinidad, their socioreligious-cultural perspectives and practices were noticeably influenced more by the Negroes than any other ethnic group. 4

In such a context, the syncretistic nature of Hinduism allowed it to borrow and incorporate certain religious beliefs and practices from the Negroes. These include worship forms of the Roman Catholic church, i.e., worshiping at. Mount st. Benedict, the headquarters for the Roman Catholic Church, and Saint La Devina Pastora at siparia. In addition, some use is made of the Negro

\section{${ }^{1}$ Ibid.}

${ }^{2}$ Barton M Schwartz, "Ritual Aspects of Caste in Trinidad," Anthropological Quarterly 37, no. 1 (January 1964): 12 .

${ }^{3}$ Malik, 28 .

${ }^{4} \mathrm{Niehoff}$ and Niehoff, 185 . 
spiritual beliefs, of local folk medicine, and the practice of a system of magic for positive and negative purposes. ${ }^{1}$

The chief proponents and practitioners of the Negro beliefs and practices are the adherents of the Shango religion which originated from the Uruba kingdom of Nigeria and the Shouters Faith, which is sometimes referred to as spiritual Baptists, and is comprised of a mixture of European Christian religious and indigenous African religious forms and practices. A wide range of prescribed formulas and remedies, with and without rituals, exist for an enormous cross-section of possible diseases and illnesses that affect both humans and animals. Remedies and rituals for exorcism, ensuring success in business ventures, school examinations, securing and promotion on jobs, dismissal of court cases when guilty, overcoming opposition to marriage, keeping a husband, wife, boy-friend, or girl-friend, getting rid of troublesome neighbors, injuring an enemy, and protection of person, family, or property in any form from evil or failure, etc. ${ }^{2}$

'Ibid., 158-169.

${ }^{2}$ George Eaton Simpson, Religious Cults of the Caribbean: Trinidad, Jamaica, and Haiti (Rio Piedras, P.R.: Institute of Cribbean Studies, University of Puerto Rico, 1970), 11-153. 
These activities which the Hindus may have seen or they believe work effectively and provide immediate results have tended to captivate some of them. They can go to the Shango yard or the Shouters' church and still remain Hindus. Moreover, I have actually seen the image of a Hindu deity on the altar in a shouters' church. In fact, not only does the Hindu, at times, go to these Negro practitioners, but the pandits themselves practice in these religious and magical forms and are seen by some of the Hindus as magicians rather than as religious leaders.

A strategy for working with Hindus in Trinidad must positively and tangibly address the subjects and themes that impinge on their interest and their preoccupation with mysticism and magic. In other words, apart from promising future prosperity and salvation, the Hindu needs to see evidences of present rewards, protection, deliverance, success, and compensation since the Christian religion is beckoning him to leave Hinduism and improve his life by becoming a christian.

There may be a need for a special outpouring of the Holy spirit that is attended with miracles (Acts 8: 5$9 ; 10 ; 9: 32-42)$, and the development of a strong faith in God and what He has done in the lives of those evangelizing the Hindus and what could be done here and now for the Hindus themselves. The gospel needs to provide tangible evidence of its being relevant to 
concrete challenges and issues here and now, and at the same time offer the assurance of brighter hope for the hereafter.

\section{Dialogue \\ (A further clarification on point $3 f$ )}

Because of the impact Christian activities have had to disrupt Hindu religious and family structures, Hindus tend to be more particular and exclusive than any of the other non-Christian religions present in

Trinidad.' Among the Christian denominations in Trinidad, Seventh-day Adventists is one of those inclined to be very exclusive. As a result, Seventh-day Adventists and Hindus appear to have a modicum of accurate informa-tion about each other's beliefs and the meaning of reli-gious practices. This situation doubtlessly contributes to the lack of trust, suspicion, and the resulting limited interaction between the two groups.

The use of the basic principles of Christian/ non-Christian dialogue should be employed to improve the inter-relationship, thereby providing an initial step in the evangelization process.

This dialogue, preferably, should not be done on an official level between the two religions because, apart from the fact that it is not likely to happen, it could be counter productive. The dialogue should be on a person-

\footnotetext{
1Malik, 43 .
} 
to-person basis where the participants share their subjective religious experience and their personal concepts of their respective religions. It should be done with respect for one another as equals and with a willingness to learn from one another. A series of such dialogues between members of both religions could assist in developing a positive, healthy relationship which can lead to the involvement of the respective families on a social level. Subsequently, as the situation and the relationship indicates, and under the guidance of the Holy spirit, a deliberate effort may be made to evangelize an entire family, using the method deemed most appropriate for that context. Regardless of the outcome, such a dialogical encounter and the resulting relationship should continue with a high frequency of optimism.

\section{Some Suggested Evangelistic Methods}

It is vitally important in the interest of success that every evangelistic method be informed by and operate within the ambit of the suggested strategy. An inexhaustive list of possible evangelistic methods is listed here. Though the nomenclature is Hindu, the resulting attitude of Hindus and the impact of the relationship between Hindu and Seventh-day Adventist individuals should guide in any readjusting of the system of labeling, so that no one is unnecesarily offended by the name of any evangelistic activity or method. 
Rites of Passage

Hindus observe the arrival of certain important stages in life with appropriate ceremonies or rituals. As Christians, Seventh-day Adventists may not be comfortable nor find an appropriate theological basis for all of these rites nor how they may be recognized, nevertheless, they can make certain adjustments and accommodations that would give permission for some rites of passage to be observed by Seventh-day Adventists of East Indian descent who might have formerly been Hindus.

\section{The Birth of a child}

The birth of a child, especially the first child, is an experience that is usually filled with much breath-less anticipation, excitement, joy, and celebration. For these reasons, the birth of a baby may be an appropriate rite of passage that can be recognized by Seventh-day Adventists of East Indian descent. Such an event may be celebrated in conjunction with the dedication of the child, with a special thanksgiving service followed by a fellowship meal. A situation like this can possess great evangelistic potential and possibilities. The service may be organized by the family concerned, with the assistance of the church, as a personal ministry project. It may be administered by the father and a pastor or very prominent church officer who is of East Indian descent. 
Before the child is known to too many persons in the community, the parents should invite personally their Hindu relatives and friends to the special ceremony. It may be best to schedule the celebration on a weekend, preferably some time in the evening. The residence and the actual venue of the ceremony should be decorated with bunting and flowers. A platform may be provided for the officiating persons during the function.

on the selected day and about thirty minutes before the time set for the event, Christian bhajans (Christian texts written in Hindi or similar language and set to Hindu musical forms) should be played over a public address system. As the guests arrive, members of the family should welcome them. The service could begin with a song service led by an East Indian musical band and singers singing some Christian bhajans in Hindi. This can be followed with an appropriate scripture, a sermonette, and dedication prayers for child and parents. Next, the child may be officially named by the parents who may testify their thankfulness to God. At that point, gifts for the child may be presented. Special music may intersperse as thought appropriate. A prayer also should be made on behalf of the people attending and the community. If the people are agriculturalists, the prayer may include requests for appropriate weather and a bountiful harvest. These activities may be followed by an 
East Indian meal served in an East Indian manner. The meal may be supplied in part by the members of the church as an evidence of their support, and they should be publicly thanked for their assistance.

This suggestion may be taken as a general idea of what may be done and should not be taken as liturgy. The prevailing situation, available personnel, and the socio-economic level of those involved should suggest the format most appropriate for that event. The activity should not be seen as an end in itself; it is ultimately establishing a relationship that may subsequently facilitate the evangelization of those Hindus who attended the function.

The Arrival of Puberty

A ceremony recognizing this stage in life may be tied in with a birthday or a graduation from primary school or the beginning of secondary-school education. Such an event probably would not be as elaborate as that conducted for the birth of a child.

This may be just an extended family or kinship gathering. There, a few bhajans may be sung to begin, followed by an appropriate scripture reading, then a testimony of thanksgiving for the stage God has enabled the child to reach, next a prayer of thanksgiving and for future guidance and the servieg of light refreshments may be the concluding activity. 
The Completion of college or

University Education

A ceremony recognizing University graduation could be quite elaborate. Apart from the family and community people, the university or college friends of the graduate should be invited either verbally or by written invitation. Particular emphasis should be placed on inviting those who are Hindus. This celebration may possess components similar to the ceremony for the birth of a child. In addition, a personal testimony could be given by the graduate highlighting God's leading and intervention in various ways that made the accomplishment possible. Furthermore, similar testimonies of other graduates and the host parents may be of inestimable value as an act of witnessing. This method of evangelism would be most appropriate for the intellectual Hindus and those of the upper socio-economic strata.

\section{The Marriage Ceremony}

When Seventh-day Adventists of East Indian descent get married, the ceremony should be elaborate and impressive in relation to the socio-economic standing of those involved. Deliberate effort should be made to ensure that this is a community event to ensure the attendance of the majority of Hindus. Where a seventhday Adventist church is in the immediate or nearby community with a substantial number of East Indian 
members, they should be involved in giving moral support and whatever other assistance they can.

since some Hindu weddings last for seven days, that tradition can be fully exploited here with the least possible inconvenience to the newly weds or the families concerned.

It is advisable that those officiating at the wedding ceremony should be prominent conference officials, district pastors, or important local church officers who are of East Indian descent and are highly respected in the community. In addition, the parents and family members of both bride and groom should participate in some aspect of the ceremony.

Some suggestions are as follow:

First, a contractual arrangement should be made with the couple and their families, assuming they are all Seventh-day Adventists, relative to incorporating some evangelistic element into the post marriage celebrations if possible, without causing any undue inconvenience. Then all the details should be worked out and agreed upon. The couple and their wedding attendants should dress in East Indian attire appropriate for the occasion. Tents or sheds could be erected at the homes of both sets of parents. These may be beautifully decorated with flowers and bunting, as is the practice with Hindus. 
The night before the wedding, male friends, relatives, and neighbors of the groom may gather at his parent's residence. There they may conduct a ceremony which can include readings from the Bible, a sermonette, singing of bhajans, and prayers of thanksgiving and imploring God's blessings on the groom and his future wife and prospective family. A wedding shower may be given in his behalf. He may respond by thanking all for what they have done and especially God for His leading and blessings in his life. This should be followed by a Hindu fellowship meal. The pastor who will be officiating at the wedding should be present and actively participate in the religious aspects of the ceremony. The parents of the bride may host a similar ceremony on her behalf. There, the pastor's wife may actively function.

on the day of the wedding, a ceremony may be conducted at the groom's parents' home. This should be a religious celebration where again the Bible is read, bhajans are sung, and divine guidance and success is sought on behalf of the groom and his prospective family. Similar activities may be conducted at the bride's parents' home. At the time of the wedding the groom with his entourage should go to the home of the bride's parents where the wedding takes place. The format and content for this aspect of the ceremony may be a contextualized form of that which is used in the average Seventh-day Adventist 
wedding, but the music could be East Indian, the posture of the bride, groom, and those officiating may be traditional squatting, the sermonette may be in story form, and the prayer may be in the form of a song. The ceremony could be followed by feasting, the donating of gifts, and the pronouncement of blessings and best wishes on the wedded couple before they leave for the honeymoon.

Festivities may continue at one of the homes each evening for a full seven days, if desired and possible. During that time the ceremonies may consist of reading about marriage and family episodes from the Bible followed by explanations, sharing of the spiritual lessons, and the singing of some bhajans. In addition, there could be special prayers for the newly weds each evening. This may be followed by a simple Hindu meal of coromar, charna, poloori, etc. It would be best if the couple returned for the final evening which should be the largest of the evening ceremonies. Such an event may be one of rejoicing and thanksgiving for what God has done and will continue to do in the future. A full meal should conclude the week's ceremonies.

It is anticipated that by bringing these people together and sharing the word of God in a social, nonthreatening situation, a process can begin under the ministry of the Holy spirit which may result in the eventual salvation of the related Hindu families. 
Again, these are only suggestions. Since no two situations are alike, constant innovation and experimentation is possible to make the wedding ceremony an evangelistic outreach to Hindu relatives and friends.

It should be emphasized here that these ritesof-passage ceremonies are to be celebrated by seventh-day Adventists of East Indian descent. They, in turn, out of love and concern will invite their Hindu friends and relatives. Then, as a result of this true concern and love, acceptance of christ may result; but if it doesn't happen, the love and friendship should continue. Worthy of note is the fact that these activities should be recognized as a preliminary establishing of a relationship and a indirect exposure to the gospel. Consequently, there is need to move cautiously with these people and try to win them eventually as a family or group.

Retirement or Sixty-fifth or Seventieth Birthday

on the arrival of retirement or the sixty-fifth or the seventieth birthday, a ceremony honoring this occasion may be conducted. It should be one of thanksgiving and celebration for all that God has done throughout life thus far. To this function, friends, relatives, peers of the celebrant, especially those who are Hindus, should be invited. There may be community singing of bhajans, guest musicians performing, 
testimonies in story form, prayer, reading from the Bible, a sermonette in story form, and a fellowship meal.

\section{Death}

When there is a death in the home of seventhday Adventists of East Indian descent, a well-organized support system should be set up to assist the family in dealing with the grief, the expense, and other issues involved with the funeral. For example, Seventh-day Adventists could fully exploit the use of the "wake" which allows for much singing, playing of bhajans, and reading from the Bible from the first night after the death until the burial. Furthermore, where possible and so desired, the family may have the freedom to perform a modified form of cremation. This may involve doing everything currently. performed for the average burial of a Seventh-day Adventist, but in addition, the body could be prepared with only those items that would aid in burning and reduce the odor of the burning flesh. The wood pile should be lighted by one so designated by the family and the fire should be started in the most convenient spot and not necessarily only in the mouth of the corpse. The impact made by such a gesture on the on-looking Hindu relatives and friends could be phenomenally positive relative to their subsequent evangelization. 
Pujas

Hindus conduct pujas for as many reasons as Christians pray. Therefore Seventh-day Adventists of East Indian descent, may conduct puja-type meetings at their homes. These should be simple and include a few bhajans, reading of appropriate scripture, a sermonette, and special prayer. Each such event should be followed by a meal which size should be determined by the focus of the occasion and the number of those attending. Since Hindus recognize pujas as offering of gifts or prayers to a god, they may be used by Seventh-day Adventists of East Indian descent as a form of thanksgiving, the seeking of guidance, protection, or assistance for any important event. These should be convened mainly to invite Hindu relatives and friends to establish or enhance relationships and expose them to the gospel in a nonthreatening situation.

Pujas may be conducted for an individual, a family, or a community. They may be conducted for some one who has recovered from a major illness, deliverance from some pending misfortune or tragedy, a child who is going away to some foreign country to study, prior to attempting some business venture, after a business success, prior to the building and at the completion of building a house, before the agricultural season, and at the close of a successful harvest. 
Bhaagwat

The Hindu ceremony of bhaggwat is usually

conducted for nine consecutive evenings. During this time readings are done from the Bhagavad Gita, followed by explanations. It is customary to have a lot of singing and instrumental music at such ceremonies. Each night's session concludes with a meal. Though this may be hosted by an individual or a family, the entire community, neighboring communities, and friends and relatives from distant places may be invited to attend. Seventh-day Adventists can effectively utilize the evangelistic possibilities that such an occasion affords.

This ceremony may be adjusted and conducted at homes of Seventh-day Adevntists of East Indian descent at any time they choose. The entire community, assuming that it is small and manageable, should be invited. A band using East Indian musical instruments like the sitar, the dholak, the tabla, harmonium, the dand-tala, and the sarangi should be provided by the church. A small choir can also be used. Both choir and instrumentalists could lead out in community singing and provide special music for the occasion. A series of readings may be done from the Bible, followed by prayers and a fellowship meal.

The biblical readings should be on subjects with which Hindus are conversant. These may include the deity, deliverance, creation, salvation, eschatology, important 
rivers, mountains, and places, prominent persons, significant incidents, etc. For the nine nights, a series on the deity may take the following form: God the supreme, God the immanent, God the creator, God the preserver and sustainer, God the protector, God the Savior, God the destroyer of evil and this evil world, God the restorer or recreator, and God of love. Preferably, these presentations should be done with slides and, where possible, the use of appropriate movies would enhance both the attendance and interest.

Here is an example of what may be done. The venue for conducting the ceremony should be decorated with pictures of biblical characters, flowers, and bunting. On any night, about thirty minutes before the program begins, bhajans may be played on the public address system. The meeting should begin with music, followed by a prayer. Next may be some special music followed by the main feature, reading from the Bible and explanations. Some more music and a prayer for the host and the community would follow. This may be concluded with a simple meal each night and a large meal the first and the last nights. It should be noted that those leading out should be of East Indian descent. The music should be in Hindi, the slides should reflect Hindu culture, and some of the presentation should be in Hindi along with the English 
translation, since this is the usual practice on television and in the movies.

This kind of ceremony may be used with many innovations, not only to establish initial relationships but as a public evangelistic meeting designed for Hindus.

\section{Drama}

Hindus have a love for drama and dance which they use to depict some religious scenes and themes. As a result, this art form may be used evangelistically. Either at a home or some community center, a series of biblical episodes may be dramatized each night over a long weekend, or over each weekend for a month or, if feasible, every night for a week.

The content may be Bible stories from both testaments or the themes like those suggested for the bhaagwat. However, the cast should be of East Indian descent, likewise the music and the scenes. It should be colorful, dynamic, captivating, and of the standard or superior to that performed by the Hindus when they are depicting episodes found in the Ramayana and the Mahabharata. A group of church members of East Indian descent may choose this as their ministry and go from place to place with their drama. 
Festivals and Religious Days

Seventh-day Adventists actively or in a modified way participate in formerly pagan festivals and religious days that have been christianized, like Christmas and Easter. Similarly, they should give study to doing the same for some Hindu special days and seasons. For example, Devali is a national holiday when the homes, businesses, and community places are lighted up with deeyas.' The Hindus are quite kind and benevolent in that they give gifts, share articles of food with others, and are generally helpful. Seventh-day Adventists may modify some of the activities of the more prominent of these occasions in such a way that biblical principles are not disregarded. Such gestures convey a positive message to the Hindus who actively participate in Christmas and some other christian religious days and festivals.

For Devali, Seventh-day Adventists may light up certain places or homes and do some welfare work. They may host a special dinner for the poor, clean up a neighborhood, paint a house or two, donate food baskets, conduct an open-air concert and serve refreshments, honor

'These are small clay containers that are about one inch deep and approximately one and one-half inches in diameter. They are of a shape similar to that of small dessert bowl. Some coconut oil or ghee is placed in each one and a cotton wick is placed in the oil. This is lighted and it serves as a candle and gives off about the same amount of light as a candle. 
Hindus who have been very helpful to the community or nation, etc.

\section{Ashrams}

The Christian ashram as it is practiced in India may not be appropriate or practical in Trinidad. However, in its place extended spiritual retreats for long weekends or for longer periods may be held, depending on the possibility of the intended participants taking part. At these retreats, the participants may be involved in spiritual direction, the practice of specified spiritual disciplines, or be trained for particular ministries. In these retreats the participants should be encouraged to live as a family, where they do everything for themselves during their time together. These may be conducted for both church members and non-members. The fact that a family setting is suggested allows meetings to be nonthreatening and positive.

\section{Film Ministry}

India's commercial film industry has ranked highest in the world for years. According to government statistics, 10 million people visit the cinema daily.

A similar statement may be made concerning Trinidad relative to the attendance at movies. In the light of that, Seventh-day Adventists should attempt to develop or

${ }^{1}$ Report of the Consultation on World Evangelization Mini-Consultation on Reaching Hindus, 21 . 
secure appropriate series of Christian films. These should be sensitive to Hindu culture. They may be shown freely in the Hindu communities in private homes or at community venues. Appropriate and meaningful follow-up should be conducted after the showing of each series of films.

In addition, where possible, these films may be shown on television and viewers should be encouraged to communicate their reaction by phone or in writing. Those who do should benefit from a follow-up program. These may include: a series of cordial home visits, an invitation to a bhaagwat, home Bible study, correspondence Bible course or what ever program the response level of the person determine to be most appropriate.

\section{Radio Ministry}

Radio programs that are culturally conditioned to the Hindu communities of Trinidad may be developed. These programs should be broadcast whenever possible as a regular feature, preferably on Radio Trinidad. This is a privately owned radio station that seems to be very sympathetic to East Indian culture. Responses should be invited so appropriate follow-up work can be done for those who listen to such programs. 


\section{Ministry for women}

As a practice, Hindu women do not work outside of the home. Consequently, a special ministry may be developed for them where they can be encouraged to meet at a given home at a particular time each day. There, passages from the Bible can be read and explained to them, they may sing some bhajans, offer prayers for specific needs and concerns, and give testimonies concerning answered prayer. However, should any decisions for Christ be made in this situation, such public expressions as baptism should be delayed while the remainder of the family is evangelized. Baptism and other forms of public demonstration of the decision to follow Jesus should be done in the context of the family, if at all possible.

\section{Literature}

The majority of literature used by the seventhday Adventist Church in Trinidad comes from the United states of America. It reflect thinking, culture, and values which are foreign. As a result, the literature is not always relevant to the Trinidad context and thinking, and this make it even less effective in ministry to the Hindus in Trinidad. Because of that situation and due to the fact that local Hindu scholars are beginning to write for their people, local Seventh-day Adventists should begin to write and produce religious literature whose content is sympathetic to the Hindus. This latent witness 
could work as yeast and eventually leaven entire families with the gospel so they eventually will accept Jesus as Lord and Savior.

Since publishing literature is an expensive business, the South Caribbean Conference of Seventh-day Adventist first may want to consider printing magazines until interest develops. Then budgets may be secured for printing small books for this ministry. Whatever literature is produced should be made available to the Hindu population at the least possible cost.

\section{Contextualization}

Though all evangelistic methods employed to evan-gelize Hindus should be contextualized, some attention is given to two aspects which, though they are not methods, substantially influence methods. Unfortunately, these aspects that are so often overlooked are architecture and liturgy.

\section{Architecture}

Church buildings should assume a pattern that is consistent with the prevailing architecture and facilitate cultural forms of worship expressions. Particular emphasis should be placed on using more circles in the structures, perhaps even to the extent of building a circular sanctuary. In addition, the surrounding walls, especially those on the side towards the streets, should have open 
spaces or large windows which may be only about three feet or an appropriate high from the ground. This would facilitate the privacy of those sitting inside but at the same time would permit those who prefer to remain outside visible access to the proceedings without causing much distraction.

In place of a platform with chairs and a pulpit, a padded platform for squatting may be provided for those leading out in the services. Where the prevailing custom in the community is to sit on the floor for such public functions, there should be no seats in the church. Instead, there should be a place at the door for leaving shoes and a mat or carpet should be on the floor for seating the congregation.

The governing principle should be creating an atmosphere that the Hindu people would find comfortable and make them feel at home whenever they attend these churches.

\section{Liturgy}

Hindus are not used to set liturgical forms for worship. Their worship is very personal and varies from home to home and from community to community. Imposing a rigid liturgy on those who become christians would be a mistake; there should be room for flexibility and creativity. 
of greater consequence would be the desire to ensure that certain basic elements of worship are included in each of these services. Services should include the singing of bhajans of praise, adoration, and thankfulness; the reading and explanation of Scripture; and prayer of adoration, confession, thankfulness, petition, and consecration. Whatever is done should be biblically based and minister to the spiritual needs of those attending.

\section{Personnel}

As far as possible, in the Hindu communities where churches are raised up, urgent attention should be given to ensure that the pastors are of East Indian descent. In addition, the district Bible worker also should be of East Indian descent. The local leadership for the church should be persons of East Indian descent who have been particularly trained for their respective roles. The members, especially the females, should be encouraged to dress in oriental dress--the sari is regularly worn by Hindu women, especially when they are attending formal or religious activities

\section{The Household Church}

Despite the relevance of these church buildings and structures, they may be used primarily for Sabbath services for those of the immediate environ. Because of the cohesiveness of the family and its important role in 
Hinduism, most of the methods recommended are to be conducted in the home or family setting. Because it is difficult to acquire church housing for new congregations in Trinidad, the establishing of the house churches may be a practical and relevant suggestion.

The services can be quite informal or formal. They may take the form of group discussion, preaching, teaching, videos, testimonies, slide presentations, skits, listening to tape-recorded sermons or lectures followed by discussion, Bible study, or quizzes. Whatever form the worship takes, three important elements should be included--community singing of adoration, praise, and thankfulness; reading from the Bible; and prayer.

\section{Family-Concern Ministries}

It has already been established that the Hindu family is closely knit and is the most important socioreligious unit. In addition, it has been noted that intra-family conflict has contributed to the unsuccessful persistence of the traditional extended family. This would suggest that a ministry to the family would be pertinent to the needs of the Hindu.

Therefore, seminars and workshops may be conducted in Hindu communities in the areas of familylife enrichment, parenting skills, conflict resolution, financial management, family planning (not limited to having children but concerned with the well being of the 
entire family for its anticipated existence), and family recreation and entertainment.

\section{Health-Concern Ministries}

A high rate of alcoholism exists among Hindus in Trinidad.' Similarly, the highest rate of parasuicide is found among young Hindu women. ${ }^{2}$ In addition, the majority of East Indians live in the environs of the Caroni swamp and the oropouche lagoon, both of which are prone to periodic flooding, thus creating a health risk for these people. Because of these circumstances and the unavailability of regular quality health care, healthoriented ministries, especially in the area of preventive medicine, would be of inestimable value to the Hindus. Particular emphasis could then be placed on sanitation and waste disposal, domestic hygiene, nutrition, cooking methods, vegetarianism, home economics, first aid, CPR, hydro-therapy, home-nursing procedures, drug abuse, the $4 \mathrm{DK}$ plan for alcoholism, breath-free seminars, stress management, and home gardening.

'Rampersad Parasram, "Alcoholism: Results of $A$ Survey," in Indian Arrival Day 30th May 1985 - Maha Sabha Day 2nd June 1985, edited by Singh and Gocool, (Siparia, Trinidad: Sookhai's Printery, 1985), 29.

${ }^{2}$ Idem, "Report of an Investigation into Parasuicide," in Singh and Gocool, 33. 
Community-Concern Ministries

Ellen G. White has suggested that

If we would humble ourselves before God, and be kind and courteous and tenderhearted and pitiful, there would be one hundred conversions to the truth where now there is only one.

In the light of this pertinent counsel, should not Seventh-day Adventists demonstrate genuine love and concern for people and their community and more actively participate in community ventures that do not compromise their faith? Would not some of the misunderstandings, suspicion, animosity, and resulting resistance to the gospel disappear? Here are some ministries that can demonstrate such concern.

\section{Task Forces}

Trained task forces should be set up in Hindu communities that can respond to certain crises. For example, in the event of a fire or local flooding or similar disaster, this task force should be able to assemble within reasonable time and arrange for or provide temporary accommodation for the victims, supplying them with the prime necessities and provide them with other needed assistance to enable these people to keep on with their lives in the crisis. This task force should also be able to assist the poor with minor house repairs and

${ }^{1} E$ llen G. White, Welfare Ministry (Washington, D.C.: Review and Herald Publishing Association, 1952), 86. 
assist persons who are attempting to build their homes themselves because they cannot afford to pay for the labor needed.

Welfare

A welfare center should be set up that is adequately stocked with proper clothing, food supplies, and other amenities needed by the particular community. The staff at the center should visit with the people in the community and seek' out those in need. The head of the household should be invited to the center and at a time when it is not too obvious and in privacy be supplied with the family's needs. Such an act would help to maintain the dignity of the person in his or her own sight and in the eyes of the family. Such a gesture cannot help but make a lasting impression on the family.

The welfare center should arrange to have medical personnel on a regular basis to offer health screening services and advise the people in the community. When- ever there is a major illness, every assistance possible should be made available.

\section{Child Care Facilities}

For single parents and poor working parents, the church should see that the ministry of a day-care or babysitting facility or system is provided. This may involve leaving children off at designated homes or arranging for 
someone to stay at home with the children, or having a central facility staffed where the children may be left.

\section{Purchasing Co-operatives}

To assist with the challenge of the present economic situation where basic food items are very expensive and in short supply, the Seventh-day Adventists in the Hindu communities should organize purchasing cooperatives. Designated persons from each co-operative should calculate the grocery and household needs of its members. The money should be collected from everyone including a small percentage to cover the cost of transportation and incidentals, and wholesale purchasing should be done. At a designated time, volunteers can parcel out each family's groceries and at the appropriate time each family can pick up its supply. Whatever money is left over should be deposited in the nearest available banking institution. Among other things, this money can be used for assisting those who temporarily lack purchasing power but are members of the co-operative. Such a system would save the members of the community quite a sum over a one-year period.

\section{Senior-citizen Service}

A system may also be set up to assist senior citizens. The assistance may include the preparation of wills, collecting pensions, collecting medicines, taking 
them to the city to make needed business transactions, and doing other out-of-home and household tasks.

\section{Funeral Attendance}

Seventh-day Adventists should make it a point to attend the funerals of Hindus in their community. They should not only comfort the bereaved but assist with food and the other work necessary for the event.

These few suggestions of community-based ministries may be performed by those who desire to evan-gelize Hindus. The list of possibilities is endless and makes provision for every one possible to actively participate. It is hoped that as these various ministries are implemented under the ministry of the Holy spirit more Hindus will see the need to accept Jesus as their Savior and Lord.

\section{Procedure for Implementation}

In order for the recommended strategy and methods to be effective, it is necessary to establish an adequate procedure for its implementation.

\section{Presentation of the Program}

The problems and challenges of evangelizing Hindus in Trinidad and the strategy that has been recommended as a possible solution should be presented in a written summary to the conference administration. Then arrangements may be made to discuss the proposal at length 
and work out the necessary logistics and possible financial implication for a pilot project.

Assuming they agree, the proposals should then be taken to the conference executive committee using a similar method of presentation. Assuming that they also agree, it should be voted as a conference project.

The next step would be for the conference administration to present the project to the Lay-Advisory committee $^{1}$ to be discussed and to select the churches for the pilot project. Assuming that they are in agreement, the entire project could be voted for implementation.

\section{Selection of Evangelists}

A targeted area should be selected for the initial implementation of this strategy. This area might well be Central Trinidad which could incorporate churches like Chaguanas, Filicity, Cunupia, Longdenville, and

Couva. A letter sent to these churches would outline some of the challenges of evangelizing Hindus, such as the small number of East Indians in the Seventh-day Adventist Church and the intention to begin the implemen-tation of a new strategy that would require some training. A request

${ }^{1}$ The Lay-Advisory committee is made up of all leading church officers of the churches and companies of the conference. They meet once every year and act on behalf of the conference constituency to vote on major conference matters that must arise, between session. 
should be made for those who feel burdened to work for these people to submit their names.

All who submit their names should be interviewed in order to verify their interest, attitude, spiritual maturity, abilities, and skills in singing, playing musical instruments, or speaking. These interviews should indicate what extra training not already included in this project may be needed. From those interviewed, the best and strategically most appropriate thirty-six should be selected, trained, monitored, and directed as they implement the strategy. In addition, regular meetings should be held with them so that while they are implementing the strategy, weaknesses may be strengthened, irrelevant aspects be deleted, and needed aspects be added as the situation demands.

Those selected may be divided into three groups of twelve as a maximum or four groups of nine as a minimum.

\section{Proposed Training}

The participants along with their district pastors, church elders, and conference officials should take part in a training workshop conducted over a long, three-day week-end.

This training may be conducted at Caribbean Union College, if facilities are available, or at camp Balandra. 
Suggested Week-End Schedule

Thursday

Time Activity

PM

5:00 Registration

6:00 Supper

7:00 Welcome, formal opening, group organization and other logistics, familiarization

8:00 Administration of test and discussion of participants' expectations. (see appendix F)

10:00 Bedtime

Friday

Time Activities

$\mathrm{AM}$

$6: 00 \quad$ Breakfast

7:15 Devotional

8:00 Panel discussion on the "Origin of Hinduism in general and in Trinidad"

9:00 Group activity: Each group will select a Bible theme, incident, story, etc., that they would like to dramatize.

10:00 Lecture \#1: Hindu socio-cultural patterns.

11:00 The Hindu family, audio-visual presentation. 12:00 Lunch 
PM

2:00 Lecture \#2: Hindu socio-cultural patterns

3:00 Open dialogue on activities so far

4:00 Preparation for Sabbath

6:00 Supper

7:00 Learning of Hindi Christian bhajans

8:30 Visual-aid lecture on "Prominent features of Hinduism... Deities"

10:00 Bedtime.

Saturday

Time Activities

AM

7:00 Breakfast

8:00 Devotional

9:00 Panel discussion on "Major Hindu Beliefs, Unit \#1".

10:30 Learning and singing of bhajans

11:30 Distribution of handouts on "Festivals and ceremonies" .

PM

$12: 00$ Lunch

2:00 Panel discússion on "Hindu Religious ceremonies".

4:00 Audio-visual presentation on "Rites of Passage"

5:00 Lecture on "Major Hindu beliefs, Unit \#2" 
6:00 Supper

7:00 Group activity: Case study on "God and

Cultures \& Christ and salvation in Hinduism"

8:00 Lecture on "Contextualization and definition and content of recommended strategy".

9:00 Drama presentations.

10:00 Bedtime.

Sunday

Time Activities

AM

$7: 00 \quad$ Breakfast

8:00 Devotional-drama

9:00 Evangelistic methods and procedures

10:00 Do's and don'ts

11:00 Administration of test (see appendix I)

12:00 Questions and answers

$12: 30$ Consecration

\section{1:15 Lunch and departure}

When the training is completed, groups would be expected to return to their churches where they will do the necessary demographic study and organize evangelistic methods that are relevant to their particular situation. Continued training will be carried out at the churches as plans are organized. As the methods are being implemented, there should be constant monitoring. At the conclusion of this initial project, all participants and 
those who closely observed and monitored it should meet. The purpose of this meeting is to evaluate what was recommended and what was actually done and make what adjustments seem necessary before a second attempt is made.

\section{Conclusion}

This strategy should always inform how and why each of the suggested methods may be used. It should be observed, however, that the list of methods was not done in an order of progression. This is due to their inherent nature. Being more flexible and less threatening than public and personal evangelitic methods now practiced among Hindus in Trinidad, many of these methods may be used concurrently. Methods that address community and family concerns, being less direct in presenting biblical teachings, may be more appropriate for virgin territories where there is no prior relationship is of no consequence. In addition, they may be used in communities where hostility and suspicion had been previously generated for these may create an opportunity for the evangelists to demonstrate genuine loving concern and help Hindus to develop trust. If and when these people are converted, they should be trained to participate in these programs which should continue as long as they are necessary.

The Iabels given to some of the different methods are academic and designed only to facilitate an 
understanding of the methods. An effort should be made to ensure that the neither labels nor any aspect of the methods offend nor embarrass the Hindus. This calls for constant adjusting and careful adaptation of the methods being used.

Relative to the implementation to the strategy, it should be noted that when it reaches the church groups, the demographic data and the targeted community will suggest the actual time table for the necessary procedures. In other words, the group structure of the community, the prevailing force of Hinduism, the relationship with Seventh-day Adventists, and careful observation will determine which methods should be used and how long a particular evangelistic project should last and at what time direct efforts should be made to secure decisions for Jesus Christ as Lord and Savior and for membership in the Seventh-day Adventist Church. 


\section{CHAPTER VI}

\section{SUMMARY AND CONCLUSION}

\section{Summary}

Chapter 1 of this project has attempted to demonstrate that some peculiar challenges faced by members of the South Caribbean Conference of Seventh-day Adventists who are involved in evangelizing Hindus in Trinidad. Consequently, there is a justified need of a project of this nature.

In chapter 2, it was proposed that evangelism is the perpetual responsibility of every member of the Church. This is definitely implied in the fact that the evangelistic commission that Jesus Christ issued was ultimately directed to everyone everywhere unto the end of the ages. The appropriate response to this commission involves making disciples of all men by teaching or preaching the gospel and by baptizing.

For the early church, the realization of an appropriate response to this commission was accomplished through a pertinent strategy that facilitated evangelistic programs which were relevant to the situations and contexts within which they ministered. The apostles met 
the challenges of each particular situation appropriately and the converts become Christians and yet retained their family or group structure, their nationality, and their culture.

Hinduism in the Trinidad context, along with its major beliefs and practices, was the primary focus of chapter 3. It was concluded that Hinduism and Seventhday Adventism are incompatible apart from the concern of both organizations for the "family" and "vegetarianism"; they are doctrinally irreconcilable. Therefore, evangelistic programs designed to win these people for Jesus Christ have to be strategically innovative and creative.

Chapter 4 contained a survey of selected literature that gave some insights into benefits that are possible from principles of indigenization, contextualization of the gospel, and dialogue between christian and non-Christian religions. In addition, attention was given to situations where some of these principles were implemented in evangelistic programs. All of these resulted in some measure of success which could be encouraging.

Based on the previous information, chapter 5 concentrated on the development of a strategy that is designed to guide those evangelizing Hindus in Trinidad so that they could develop appropriate and intentional 
methods and programs. Following this, a variety of possible evangelic approaches and programs are suggested to guide evangelists relative to the vast possibilities of options that are available for creation and innovation. In conclusion, a suggested method for the implementation of the strategy and developing evangelistic programs was presented.

\section{Conclusions}

It is assumed that this project is practical and workable. However, since the principles and recommendations were not implemented and empirically tested, it is hoped that this project is viewed as workable suggestions. Therefore, it is anticipated that after any part of this project is implemented, careful evaluations and appropriate adjustments be made. Then it should be tried again and adjustments implemented. Consequently, it is hoped that this project will eventually evolve into a text for training both pastors and members of the seventhday Adventist Church in evangelizing Hindus not only in Trinidad but in other areas of the Caribbean Union Conference of Seventh-day Adventists.

It is also hoped that such a text would not be a reference source with quick-fix solutions nor ready-made evangelistic programs. Instead, it should offer examples, and suggestions and raise pertinent questions that will challenge the readers to think through what they desire to 
do and come up with intentionality in continuing to innovate and experiment with programs as the different situations dictate. In other words, the guiding principles should be the same for all situations but the individual programs should be different.

\section{Recommendations}

In light of the problems faced by those of the South Caribbean Conference of Seventh-day Adventist with respect to evangelizing Hindus, and the information that has surfaced from this project report, it is recommended that:

1. The South Caribbean Conference of Seventh-day Adventists give urgent study to the setting up of a subdepartment under the Church Ministries department headed by a person of East Indian descent, preferably a former Hindu or someone knowledgeable about Hinduism and concerned for the salvation of these people. This person should be responsible for coordinating the training of personnel and all evangelistic endeavor among Hindus.

2. As far as possible, pastors of Eastern Indian descent who are interested in evangelizing Hindus should be assigned to districts with a substantially large Hindu populations.

3. Caribbean Union College should introduce a survey course in the appreciation of Hinduism. 
4. Since Hindus live in st. Vincent, Guyana, and Grenada, the Caribbean Union Conference of Seventh-day Adventists should give urgent study to the establishment of an institute of Evangelism for Hindus that should interact with similar institutes or organizations from the Far Eastern Division and the Southern Asia Division so as to develop a data bank that facilitates successful evangelization of Hindus.

5. Despite all that has been recommended and can be done, all evangelists should be fully subject to the ministry of the Holy spirit who alone truly knows what really ought to be done and how it ought to be done so that all Hindus possible will be saved for the kingdom of God. 


\section{APPENDICES}


APPENDIX A

MAPS 
MAP OF INDIA 
MAPS OF THE REPUBLIC OF TRINIDAD AND TOBAGO 


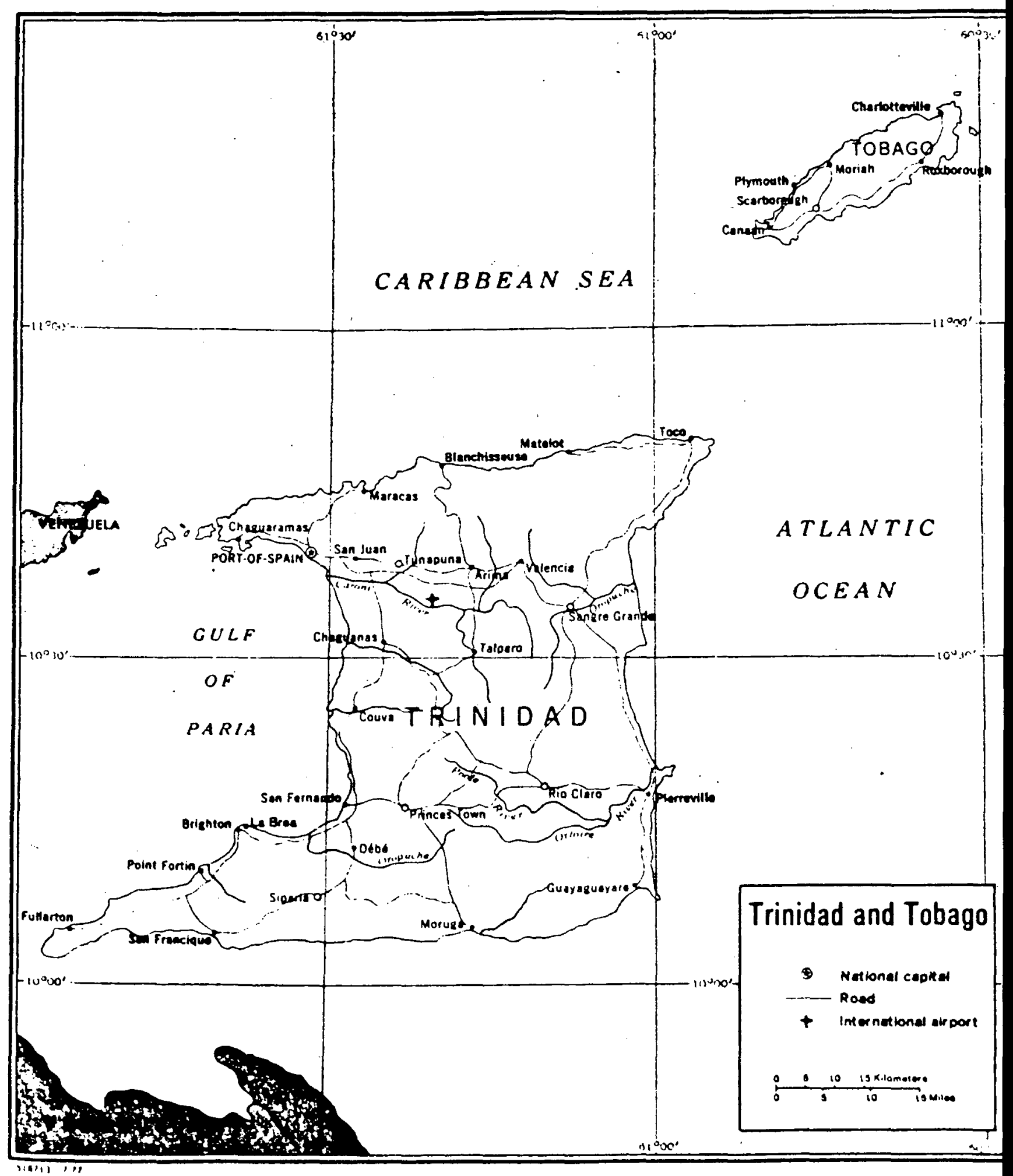




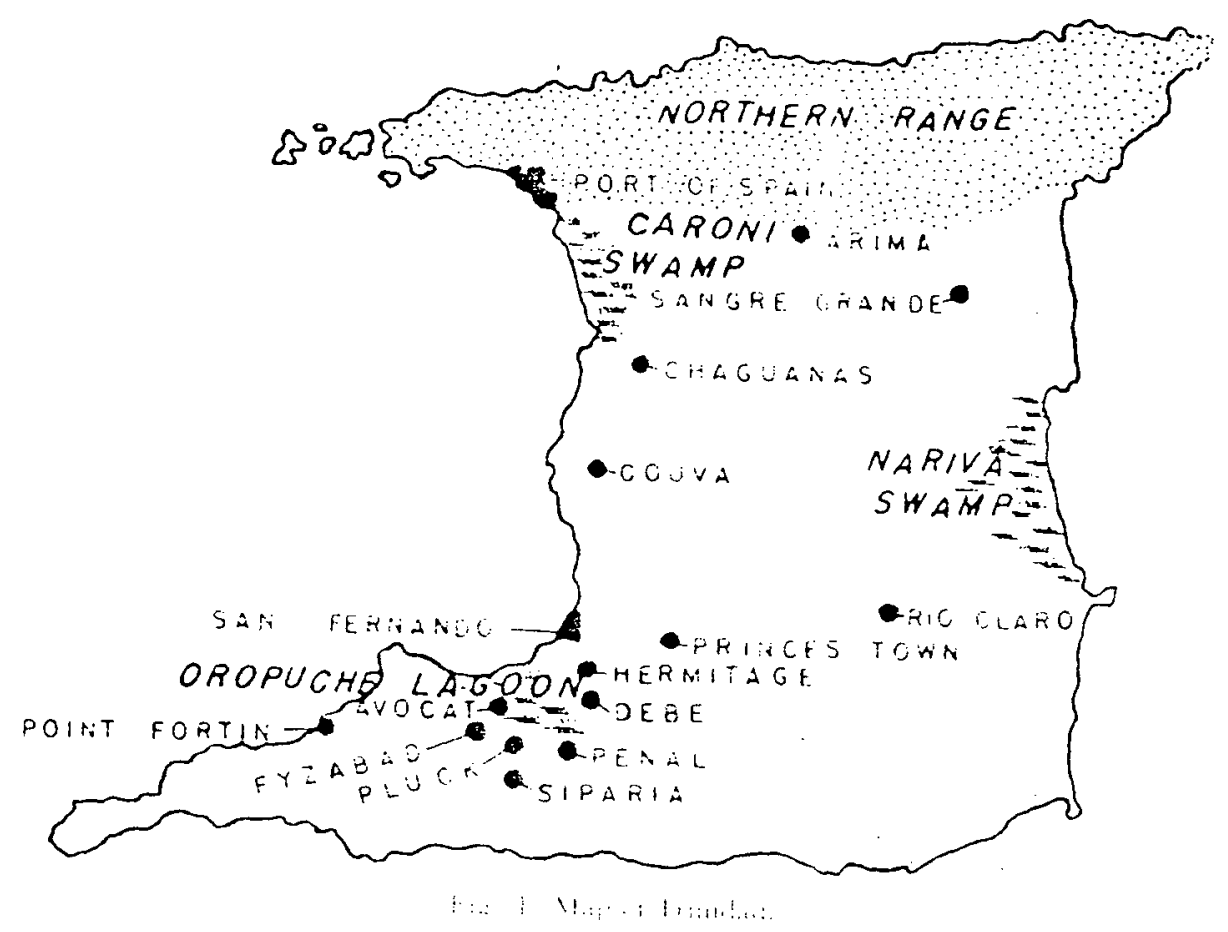




\section{APPENDIX B}

STATISTICS OF POPULATION OF THE REPUBLIC OF TRINIDAD AND TOBAGO AT NATIONAL

CENSUS 1961-1980 
10

$\therefore$ Propulation

TABLE 9. POPULATION OF TRINIDAD AND TOBAGO AT CENSUS DATES 1861-1980

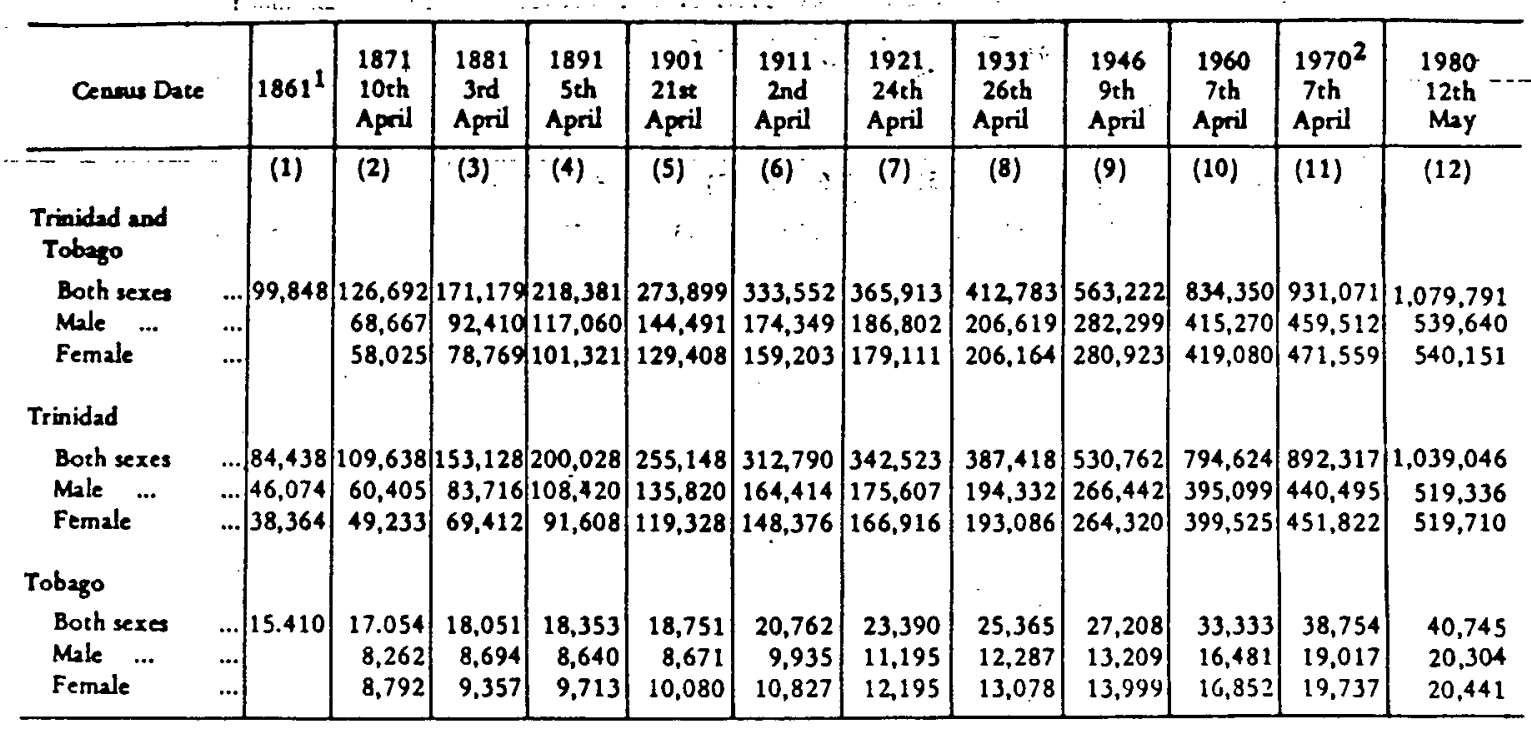

${ }^{1}$ Census taken separately in Trinidad and Tobago.

21970 Non-Institutional Population unadjusted.

Source: 5

TABLE 10. POPULATION GROWTH 1974-1983

\begin{tabular}{|c|c|c|c|c|c|c|c|c|}
\hline & & \multirow{2}{*}{ Year } & & \multicolumn{5}{|c|}{ Changes during year } \\
\hline & & & & Live births & Deachs & Natural increase & Net migration & Toual increase \\
\hline & & & & (1) & (2) & (3) & (4) & (5) \\
\hline 1974 & $\cdots$ & $\cdots$ & $\cdots$ & 26138 & 6716 & 19422 & -6670 & 12760 \\
\hline 1975 & $\ldots$ & $\cdots$ & $\cdots$ & 25673 & 6899 & 18774 & -7840 & 10934 \\
\hline 1976 & $\ldots$ & $\cdots$ & $\ldots$ & 27149 & 7388 & 19761 & -2200 & 17561 \\
\hline 1977 & $\cdots$ & $\cdots$ & $\cdots$ & 27895 & 7311 & 20584 & -2570 & 18014 \\
\hline 1978 & $\cdots$ & $\ldots$ & $\ldots$ & 28295 & 6824 & 21471 & -10550 & 11121 \\
\hline 1979 & $\cdots$ & $\cdots$ & $\cdots$ & 29698 & 7060 & 22638 & -9260 & 13378 \\
\hline 1980 & $\cdots$ & $\cdots$ & $\cdots$ & 29869 & 7506 & 22363 & -4440 & 17923 \\
\hline 1981 & $\cdots$ & $\cdots$ & $\cdots$ & 32177 & 7355 & 24822 & -5470 & 19352 \\
\hline 1982 & $\ldots$ & $\ldots$ & $\ldots$ & 32537 & 7641 & 24896 & $+3654 P$ & $28550 P$ \\
\hline 1983 & $\ldots$ & $\cdots$ & $\cdots$ & 33208 & 7546 & 25662 & $+1053 \mathrm{P}$ & $26715 P$ \\
\hline
\end{tabular}

Source: 10 
POPULATION

14

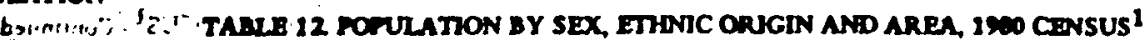

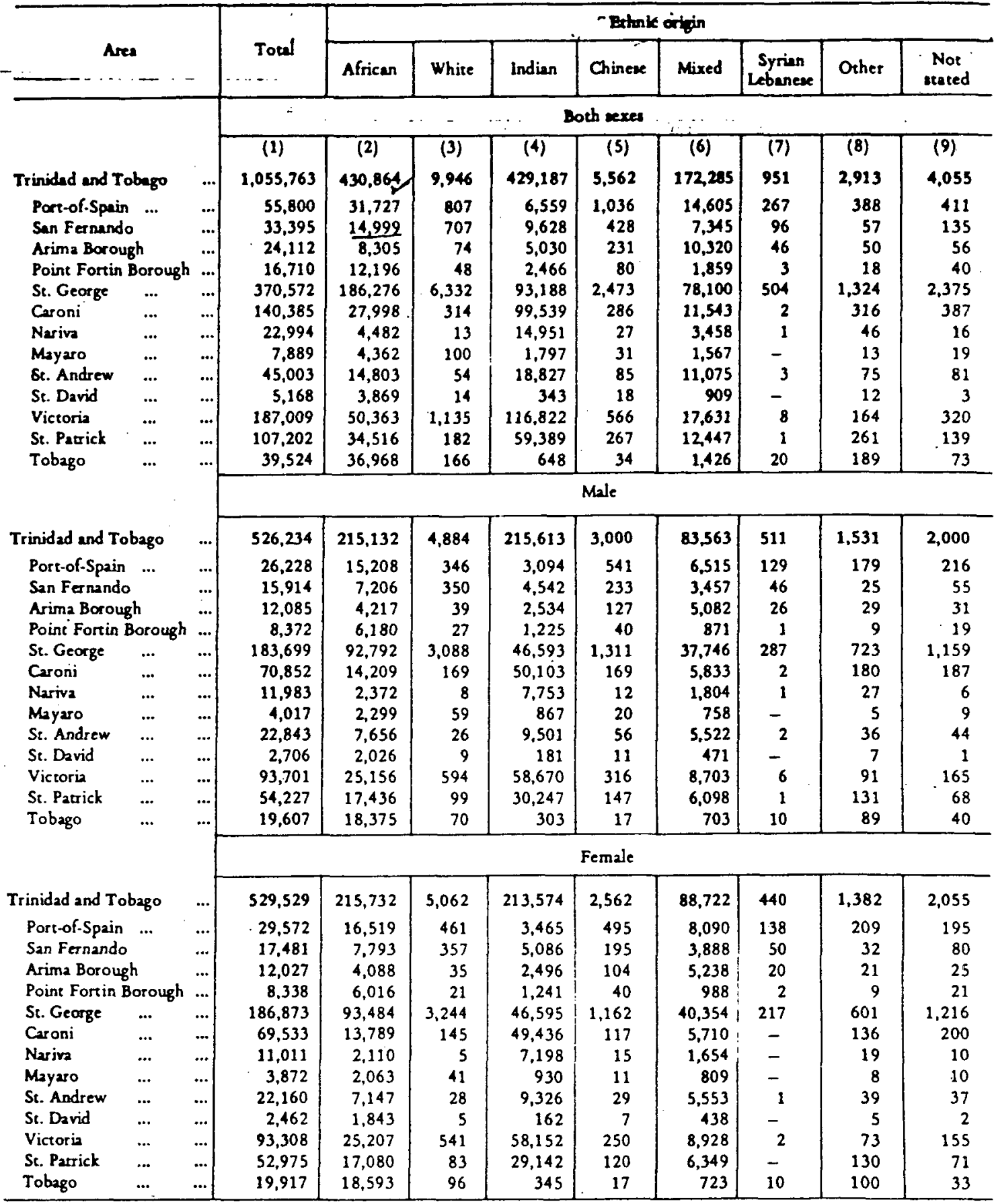

${ }^{1}$ Table excludes 24,028 persons, of which, 3,281 were in hospitals, nursing homes, prisons and leprosaria, and 20,747 whose ethnic origin and other characteristics were not available. 
is

POPULATION

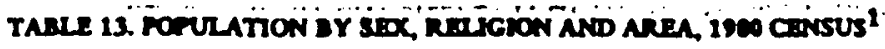

\begin{tabular}{|c|c|c|c|c|c|c|c|c|c|c|c|c|c|c|c|}
\hline \multirow{2}{*}{\multicolumn{3}{|c|}{ Ares }} & \multicolumn{13}{|c|}{$\therefore$." Religdoen } \\
\hline & & & Totel & \multirow[t]{2}{*}{ Andican } & \multirow[t]{2}{*}{ Bepetin } & \multirow[t]{2}{*}{$\begin{array}{l}\text { Jehorah } \\
\text { Witseas }\end{array}$} & \multirow[t]{2}{*}{ Hindu } & \multirow[t]{2}{*}{ Method- } & \multirow{2}{*}{$\frac{\mid \begin{array}{l}\text { Pente } \\
\text { cootel }\end{array}}{\text { oth Sexea }}$} & \multirow[t]{2}{*}{ Muelim } & \multirow[t]{2}{*}{$\begin{array}{l}\text { Prosby- } \\
\text { cerien }\end{array}$} & \multirow[t]{2}{*}{$\begin{array}{l}\text { Romen } \\
\text { Cacholic }\end{array}$} & \multirow[t]{2}{*}{ Ad- } & \multirow[t]{2}{*}{ None } & \multirow[t]{2}{*}{$\begin{array}{c}\text { Other } \\
\text { not wated }\end{array}$} \\
\hline & & & & & & & & & & & & & & & \\
\hline & & & (1) & (2) & (3) & (4) & (5) & (6) & (7) & (8) & (9) & (10) & (11) & $(12)$ & (13) \\
\hline \multicolumn{3}{|c|}{ Trinidad and Tobago ... } & $1,055,763$ & 155,155 & 25,333 & 8,021 & 262,917 & 15,118 & 36,451 & 63,333 & 40,275 & 347,740 & 26,268 & 10,392 & 64,760 \\
\hline \multicolumn{2}{|c|}{ Port-of-Spain } & $\ldots$ & 55,800 & 14,774 & 987 & 528 & 1,407 & 1,320 & 1,034 & 1,324 & 598 & 29,194 & 1,093 & 591 & 2,9502 \\
\hline San Fernand & & $\ldots$ & 33,395 & 6,747 & 732 & 311 & $\therefore 2,871$ & 599 & 1,827 & 1,645 & 2,789 & 12,852 & (6I) & 298 & 2,107 . \\
\hline Arima Boros & & $\ldots$ & 24,112 & 2,477 & 283 & 174 & 1,640 & 166 & 601 & 960 & 436 & 15,558 & 654 & 160 & 1,003 \\
\hline Point Fortin & Boro & & 16,710 & 3,560 & 556 & 237 & 1,313 & 137 & 504 & 324 & 288 & 7,068 & 735 & 200 & 1,788 \\
\hline St. George & $\ldots$ & $\ldots$ & 370,572 & 70,172 & 6,758 & 3,433 & .49 .693 & 6,168 & 13,293 & 14,783 & 7,374 & 163.591 & 9.805 & 4,896 & 20,606 \\
\hline Caroni & $\ldots$ & $\ldots$ & 140,385 & 9,775 & 1,880 & 849 & 68.859 & 1,107 & 3,699 & 15,075 & 6,209 & 24,474 & 1,752 & 703 & 6,003 \\
\hline Nariva & $\ldots$ & $\ldots$ & 22,994 & 821 & 822 & 95 & 9.652 & 11 & 796 & 2,272 & 1,270 & 5,752 & 518 & 156 & 829 \\
\hline Mayaro & $\ldots$ & $\ldots$ & 7,889 & 775 & 324 & 126 & 829 & 26 & 177 & 137 & 177 & 4,163 & 292 & 105 & 758 \\
\hline St. Andrew & $\ldots$ & $\ldots$ & 45,003 & 3,831 & 950 & 247 & 10,826 & 114 & 1,347 & 2,415 & 1,892 & 19,183 & 1,779 & 381 & 2,038 \\
\hline St. David & $\ldots$ & $\ldots$ & 5,168 & 1,270 & 229 & 10 & 60 & 4 & 160 & 24 & 18 & 2,394 & 605 & 83 & 311 \\
\hline Victoria & $\ldots$ & ... & 187,009 & 17,493 & 9.099 & 1,043 & 72.219 & 1,064 & 8,130 & 18,480 & 13,541 & 31,435 & 2,388 & 1,343 & 10,074 \\
\hline St. Patrick & $\cdots$ & ... & 107,202 & 9.594 & 1.770 & 679 & 42.678 & 448 & 2,689 & 5,788 & 5,634 & 28.299 & 1,831 & 586 & 7,213 \\
\hline Tobago & $\cdots$ & ... & 39,524 & 13,866 & 943 & 289 & 177 & 3,954 & 2,194 & 106 & 49 & 3,777 & 4,199 & 890 & 9,080 \\
\hline & & & & & & & & & Male & & & & & & \\
\hline Trinidad and 7 & cobag & o ... & 526,234 & 79,450 & 11.582 & 3,616 & 133,470 & 7,461 & 16,202 & 32,198 & 20,088 & 172,737 & 11,967 & 6,745 & 30,718 \\
\hline Port-of-Spain & & $\ldots$ & 26.228 & 7.114 & 380 & 219 & 656 & 634 & 401 & 679 & 260 & 13,634 & 459 & 401 & 1,391 \\
\hline San Fernand & & ... & 15,914 & 3,388 & 308 & 136 & 1.374 & 266 & 785 & 827 & 1,300 & 6,162 & 227 & 209 & 932 \\
\hline Arima Borou & & ... & 12,085 & 1,311 & 136 & 69 & 834 & 69 & $24 \dot{5}$ & 483 & 230 & 7,836 & 299 & 110 & 463 \\
\hline Point Fortin & Boro & & 8,372 & 1,900 & 234 & 99 & 664 & 76 & 229 & 181 & 135 & 3,608 & 351 & 141 & 754 \\
\hline St. George & $\ldots$ & $\ldots$ & 183,699 & 35,881 & 2,937 & 1,532 & 25,208 & 3,078 & 5,765 & 7,465 & 3,683 & 80,761 & 4,422 & 3,085 & 9,862 \\
\hline Caroni & $\ldots$ & $\ldots$ & 70,852 & 5,119 & 856 & 404 & 34,862 & 563 & 1,694 & 7,557 & 3,165 & 12,500 & 823 & 415 & 2,894 \\
\hline Nariva & $\ldots$ & $\ldots$ & 11,983 & 429 & 417 & 50 & 5,029 & 7 & 400 & 1,181 & 669 & 3,017 & 251 & $108:$ & 425 \\
\hline Mayaro & $\ldots$ & $\ldots$ & 4,017 & 460 & 155 & 61 & 395 & 17 & 83 & 62 & 85 & 2,127 & 133 & 80 & 359 \\
\hline St. Andrew & $\ldots$ & $\ldots$ & 22,843 & 2,067 & 440 & 115 & 5,532 & 56 & 592 & 1,264 & 920 & 9,826 & 823 & 234 & 974 \\
\hline St. David & $\ldots$ & $\ldots$ & 2,706 & 696 & 105 & 5 & 37 & 3 & 77 & 12 & 11 & 1,258 & 278 & 67 & 157 \\
\hline Victori2 & $\ldots$ & ... & 93,701 & 8,919 & 4,400 & 463 & 36,891 & 557 & 3,758 & 9,441 & 6,794 & 15,729 & 1,062 & 860 & 4,827 \\
\hline St. Patrick & $\ldots$ & $\ldots$ & 54,227 & 5,056 & 778 & 319 & 21,903 & 224 & 1,216 & 2,988 & 2,815 & 14,395 & 830 & 407 & 3,296 \\
\hline Tobago & $\ldots$ & $\ldots$ & 19,607 & 7,110 & 436 & 144 & 85 & 1.911 & 937 & 58 & 21 & 1,884 & 2,009 & 628 & $.4,384$ \\
\hline & & & & & & & & & Female & & & & & & \\
\hline Trinid $2 d$ and $T$ & obag & ... & 529,529 & 75,705 & 13,751 & 4,405 & 129,447 & 7,657 & 20,249 & 31,135 & 20,187 & 175,003 & 14,301 & 3,647 & 34,042 \\
\hline Port-of-Spain & & $\ldots$ & 29,572 & 7.660 & 607 & 309 & 751 & 686 & 633 & 645 & 338 & 15,560 & 634 & 190 & 1,559 \\
\hline San Fernand & & $\ldots$ & 17,481 & 3,359 & 424 & 175 & 1,497 & 333 & 1,042 & 818 & 1.489 & 6,690 & 390 & 89 & 1,175 \\
\hline Arima Borou & gh & $\ldots$ & 12,027 & 1.166 & 147 & 105 & 806 & 97 & 356 & 477 & 206 & 7,722 & 355 & 50 & 540 \\
\hline Paias Fortin & Boro: & & 8,338 & 1.660 & 322 & 138 & 649 & 61 & 275 & 143 & 153 & 3,460 & 384 & 59 & 1,034 \\
\hline Se. George & $\ldots$ & $\ldots$ & 186,873 & 34,291 & 3,821 & 1,901 & 24,485 & 3,090 & 7,508 & 7,318 & 3,691 & 82,830 & 5,383 & 1,811 & 10,744 \\
\hline Curoni & $\cdots$ & ... & 69.533 & 4,656 & 1,024 & 44 & 33,997 & 544 & 2,005 & 7,518 & 3,044 & 11,974 & 929 & 288 & 3,109 \\
\hline & $\cdots$ & ... & 11,011 & 392 & 405 & 45 & 4,623 & 4 & 396 & 1,091 & 601 & 2,735 & 267 & 48 & 404 \\
\hline Mrsaro & .. & $\ldots$ & 3,872 & 315 & 169 & 65 & 434 & 9 & 94 & 75 & 92 & 2,036 & 159 & 25 & 399 \\
\hline Se. Andrew & $\cdots$ & $\ldots$ & 22,160 & 1,764 & 510 & 132 & 5.294 & 58 & 755 & 1,151 & 972 & 9.357 & 956 & 147 & 1,064 \\
\hline & ... & $\ldots$ & 2.462 & 574 & 124 & 5 & 23 & 1 & 83 & 12 & 7 & 1,136 & 327 & 16 & 154 \\
\hline & $\cdots$ & $\ldots$ & 93,308 & 8,574 & 4,699 & 580 & 36,028 & 507 & 4,372 & 9,039 & 6.747 & 15,706 & 1,326 & 483 & 5,247 \\
\hline & ... & ... & 52,975 & 4,538 & 992 & 360 & 20,768 & 224 & 1,473 & 2,800 & 2,819 & 13,904 & 1,001 & 179 & 3,917 \\
\hline & $\cdots$ & $\ldots$ & 19,917 & 6.756 & 507 & 145 & 92 & 2,043 & 1,257 & 48 & 28 & 1,893 & 2,190 & 262 & 4,696 \\
\hline
\end{tabular}

${ }^{1}$ Table excludes 24,028 persons, of which 3,281 were in hospitals, aursing homes, prisons and leprosaria, and 20,747 whose ethric orian and other characteristics were not available. 
APPENDIX C

LETTERS 
LETTER AND ACCOMANYING DATA FROM SOUTH CARIBBEAN CONFERENCE OF SEVENTH-DAY ADVENTIST 


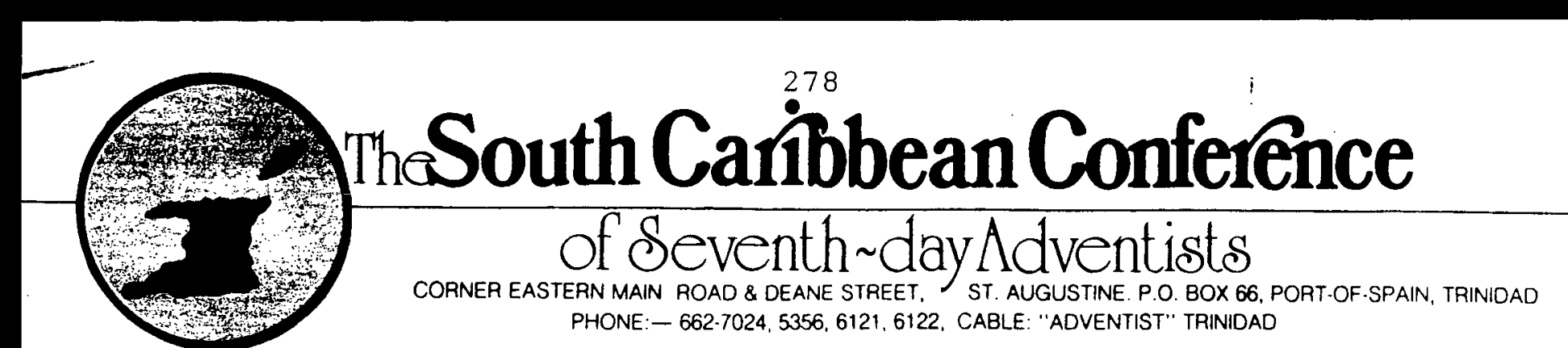

November 18: 1988

Mr. Wynall F. Kerr

600 Beechwood B-41

Berrien Springs MI 49103

U.S.A.

\section{Dear Bro Kerr}

Christian Greetings! We received your letter requesting statistics in the area of Hinduism for your research. Because of the fact that we do not register our baptised members by their race it was indeed difficult to get this information from our files. However. we have used average figures for most of the answers. which we trust will be able to assist you.

May God continue to bless as you pursue your studies to become a better servant in the work of the Lord.

Yours faithfully,

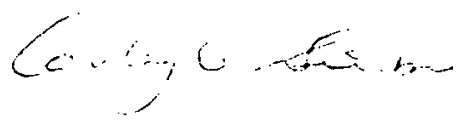

CARLYLE SCOBIE

Secretary

CS/crt

Encl./Completed Questionaire 
S.D.A. Theological Seminar:

Andrews University

Doctoral Project Questionnaire

1. Total Membership of South Caribbean Conference of S.D.A.

2. Total Number of East Indians who are Members

3. Number of East Indian S.D.A's who baptised out of Hinduism

4. Number of East Indian S.D.A's who wore baptised out of other Christian Churches

5. Number of East Indian S.D.A's who were baptised out of other Eastern religions

6. The Number of S.D.A. Churches with $0-20 \%$ East Indians

7. The Number of S.D.A. Churches with $30-50 \%$ East Incians 12

8. The Number of S.D.A. Churches with $50-80 \%$ East Indians

9. The Number of S.D.A. Churches with over $80 \%$ East Indians

10. Total Number of Pastors in South Caribbean Conference

11. Number of East Indian Pastors
(a). Licensed
(b). Credentiaiec

12. Number of East Indian liorkers
(a). Licensed
(b). Crecientiaies 
LETTER FROM THE OFFICE OF THE PRIME MINISTER

OF THE REPUBLIC OF TRINIDAD AND TOBAGO 


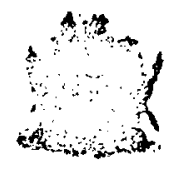

OFILE OF THE PRIACE MINISTER

DIITSHALL, PORT-OP-SPAN, THINIDAD, TRINIDAD AND TORAGO

.11th. Sartivabur.

.9 .66

Dear S1r,

With reierence to Cabinet's decision that the das on hiob DIval1 10 observed aball be a publlo.hollday, Hill you be lind envugh to inform mo wother 10th Iorember is the fired date for the obaervation of Divali.

\section{Toura fal theully,}

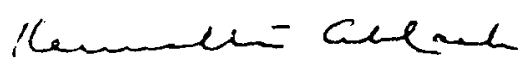

Fublio Relations Oefloer.

The President General, Sarstan Dbarma Maha Salba, Eastery Kain Rosd, St. Augustine.
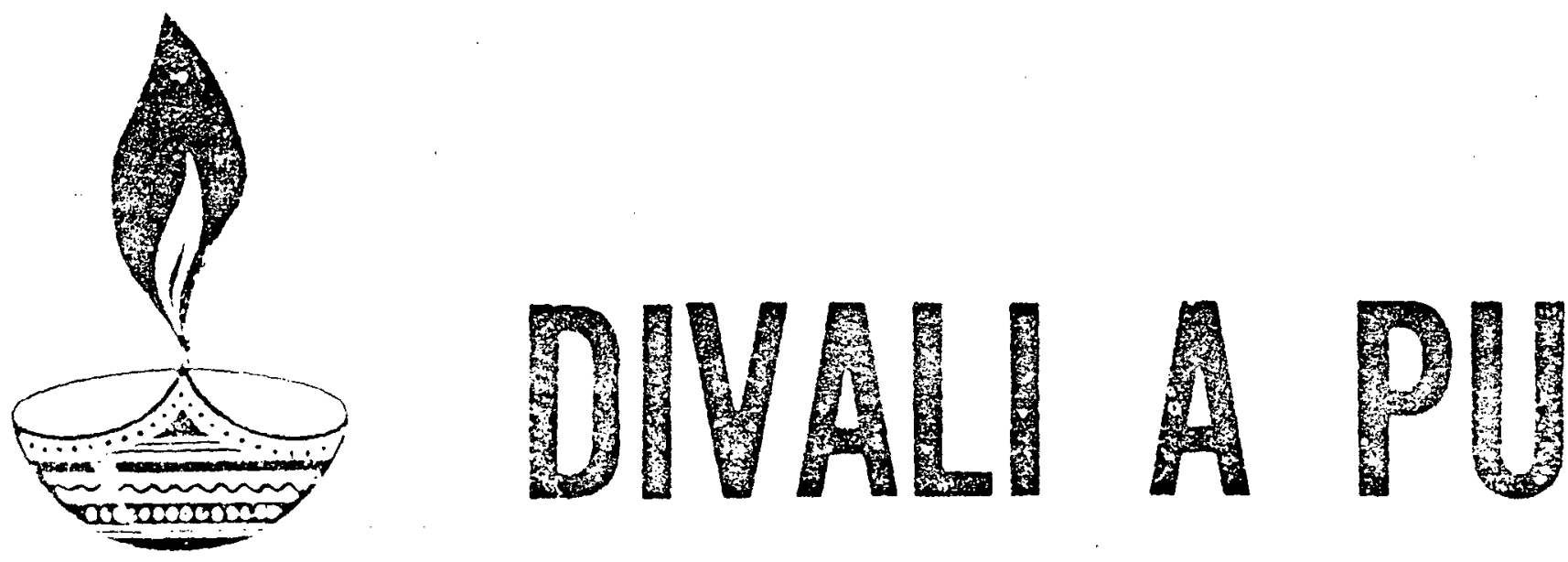
LETTER FROM THE SANATAN DHARMA MAHA-SABHA

OF TRINIDAD AND TOBAGO INCORPORATED 


\section{TAN DHARMA MAHA - SABHA OF TRINIDAD \& TOBAGO IMCORPORATI}

\section{EDUCATION BOARD OF MANAGEMENT}

HADASE sagan marAJ

Chairman

The Rt. Hon. Dre Bro W11210ms,

Prim ibinistar.

Irin:cad and Tobago,

Wivito iall.

St. Clair,

PORP-OPSBRATI.

Dear 81r.
HEADQUARTERS

Eastern Main Roa.

St. Auguetine

20th Septeaber,

196

I thenk you ror ro: 1 itter dated Lth Septomber, 1966 and in roply to stete that in provlous letter of th 7th July, 1966 I had mentilen that "Diveil" The Faativel of If thts wll be colebrated on the 22th Norember. 1966. I now oonfire that "Divali" wil be celebreted by itindue in mrintan and rouge wa the above date.
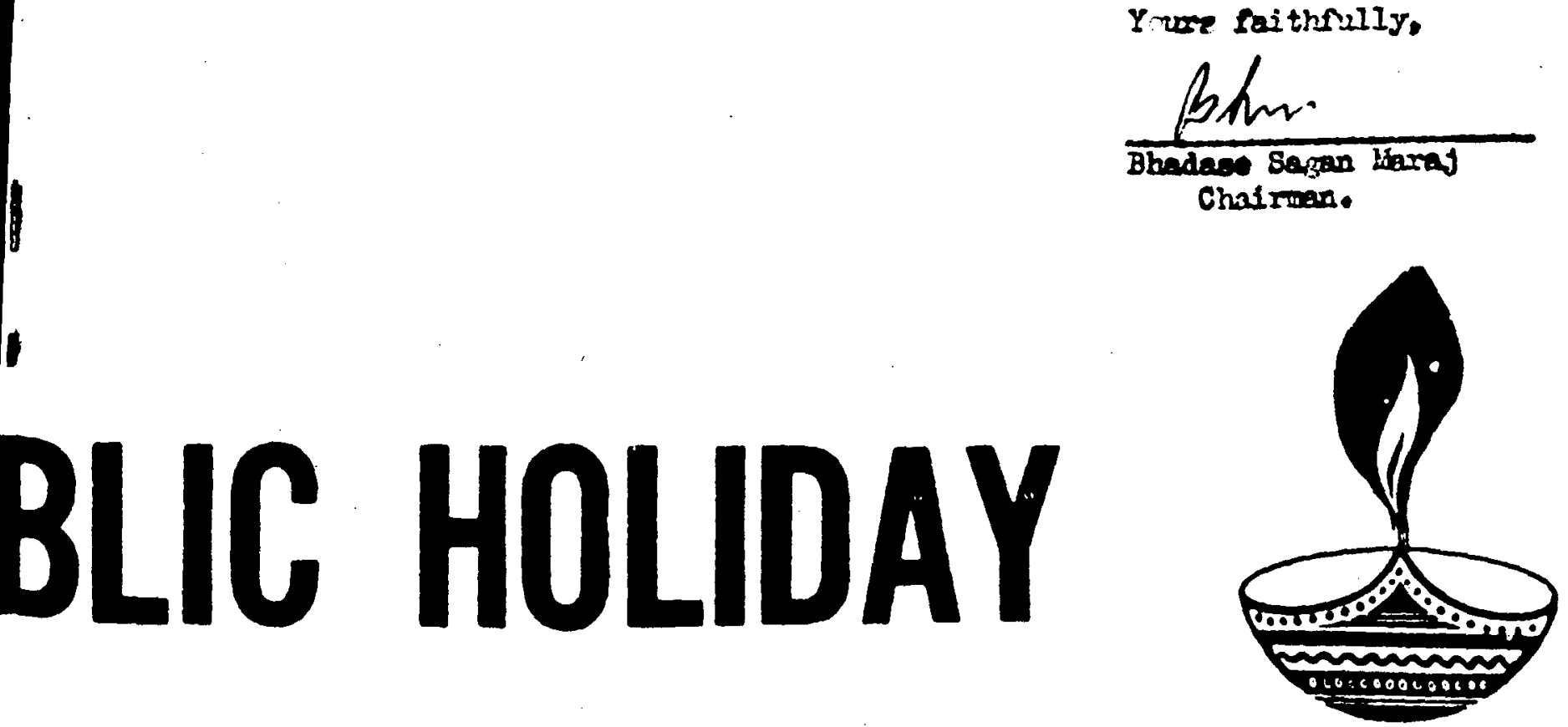
APPENDIX D

HINDU DEITIES 


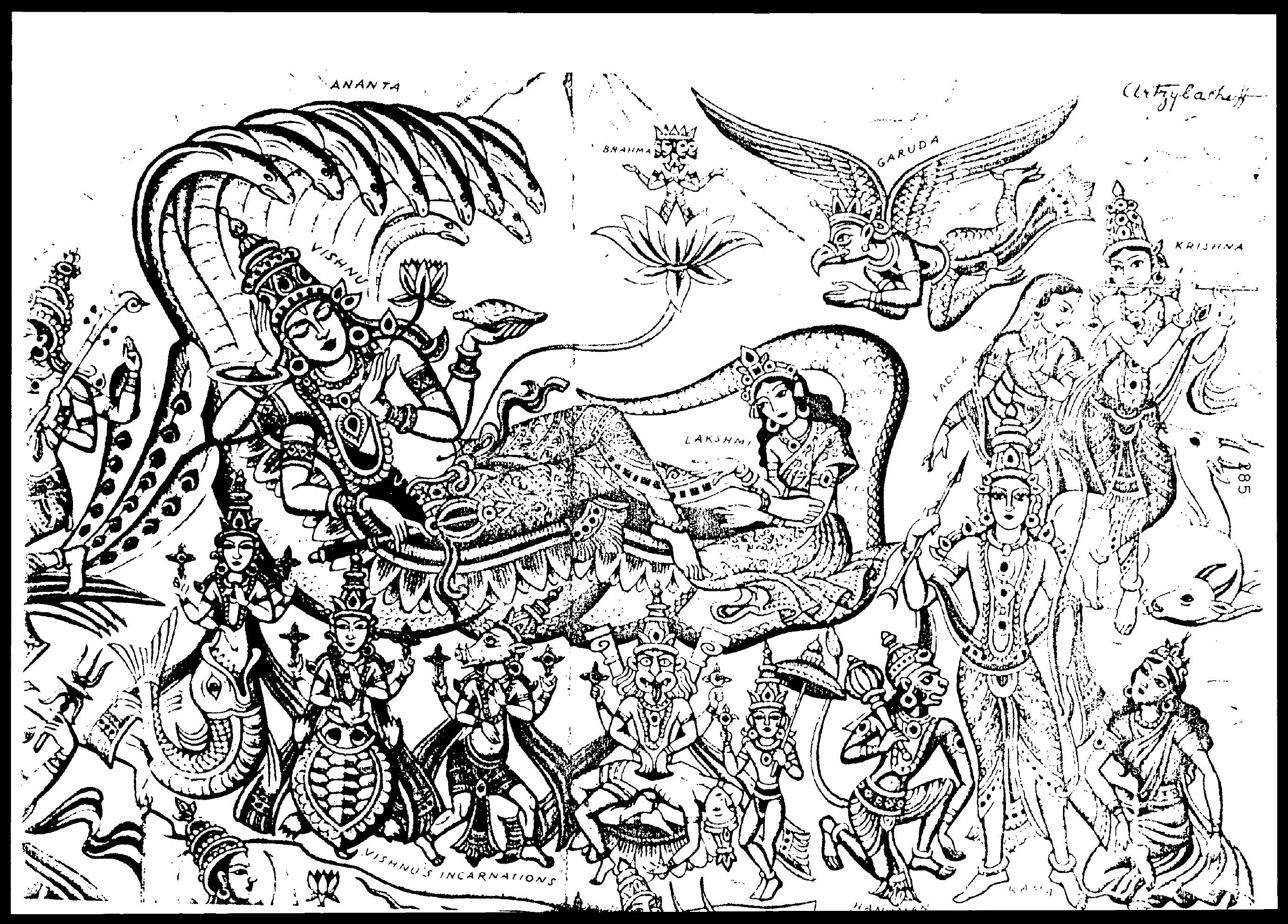




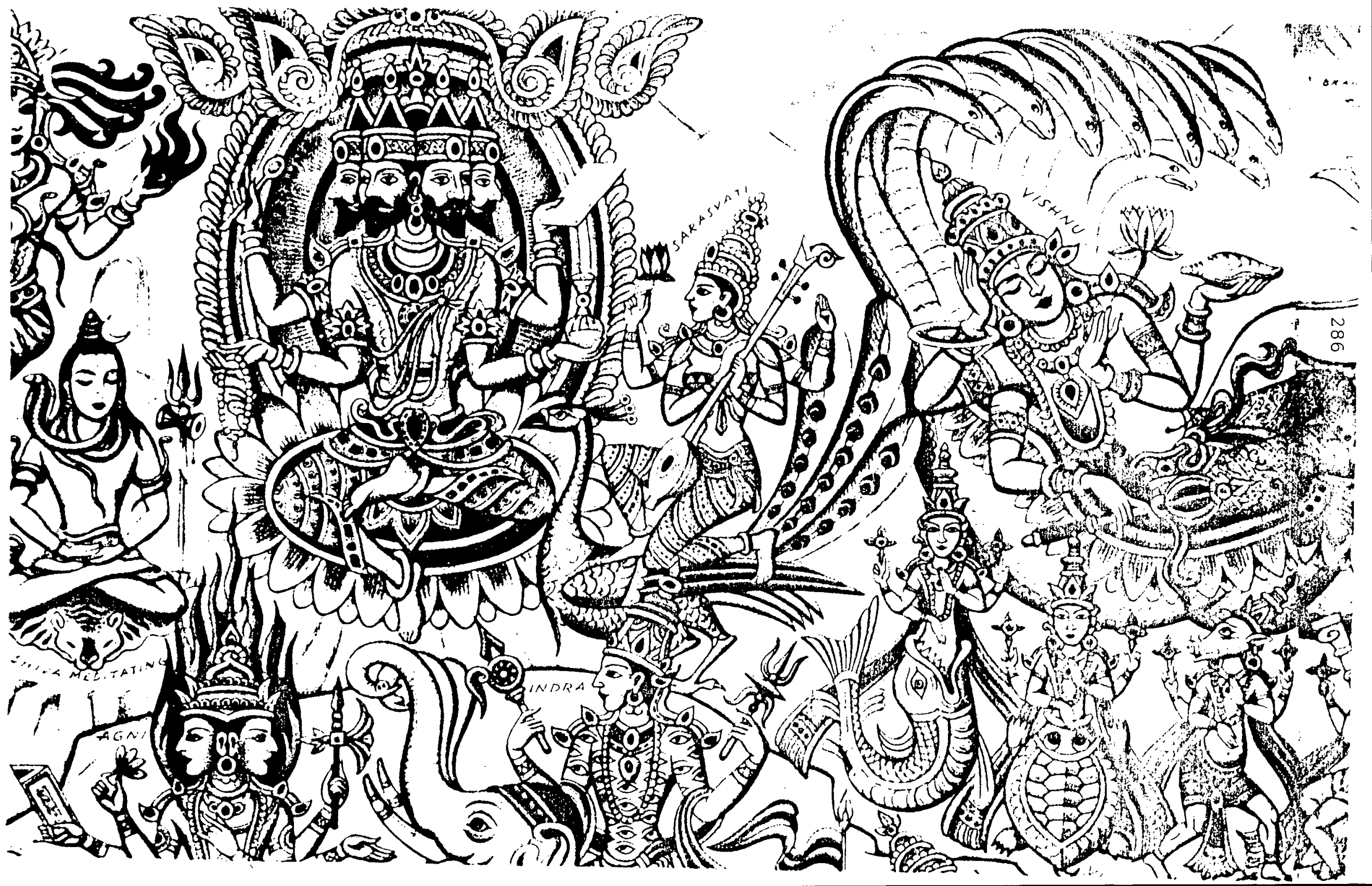




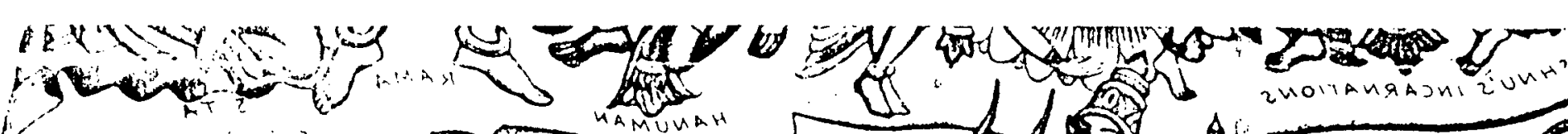
V (1)

4
$\infty$
$\infty$

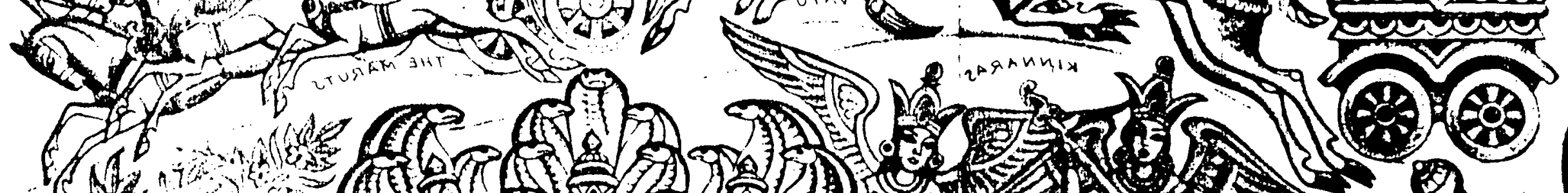

(4) 3. for

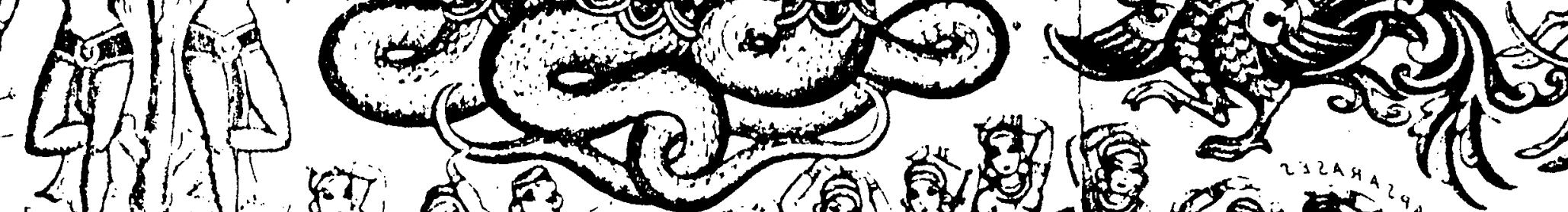

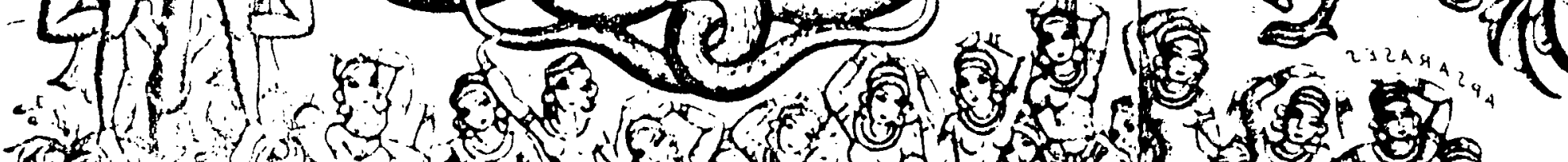
(c) 


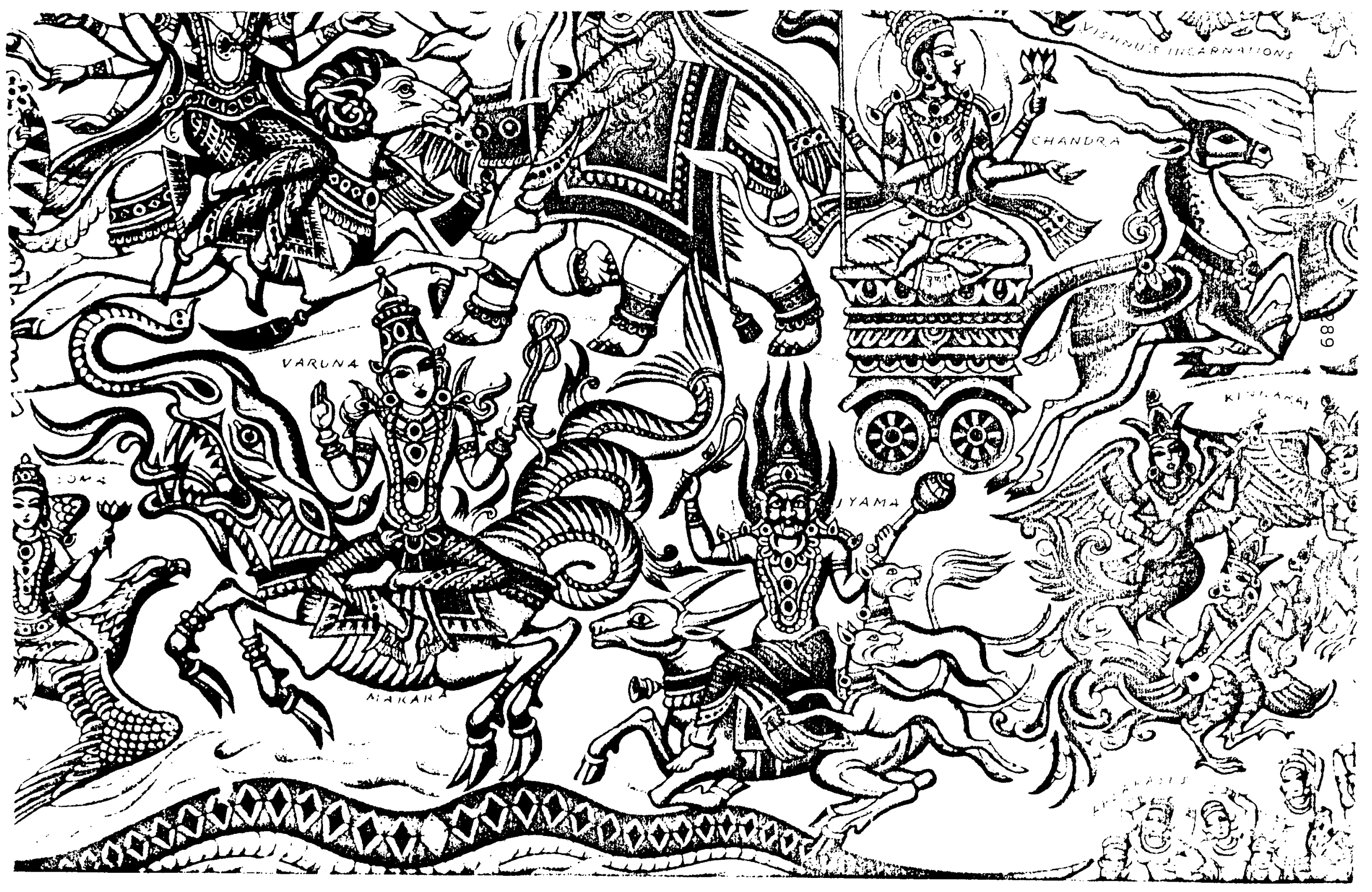




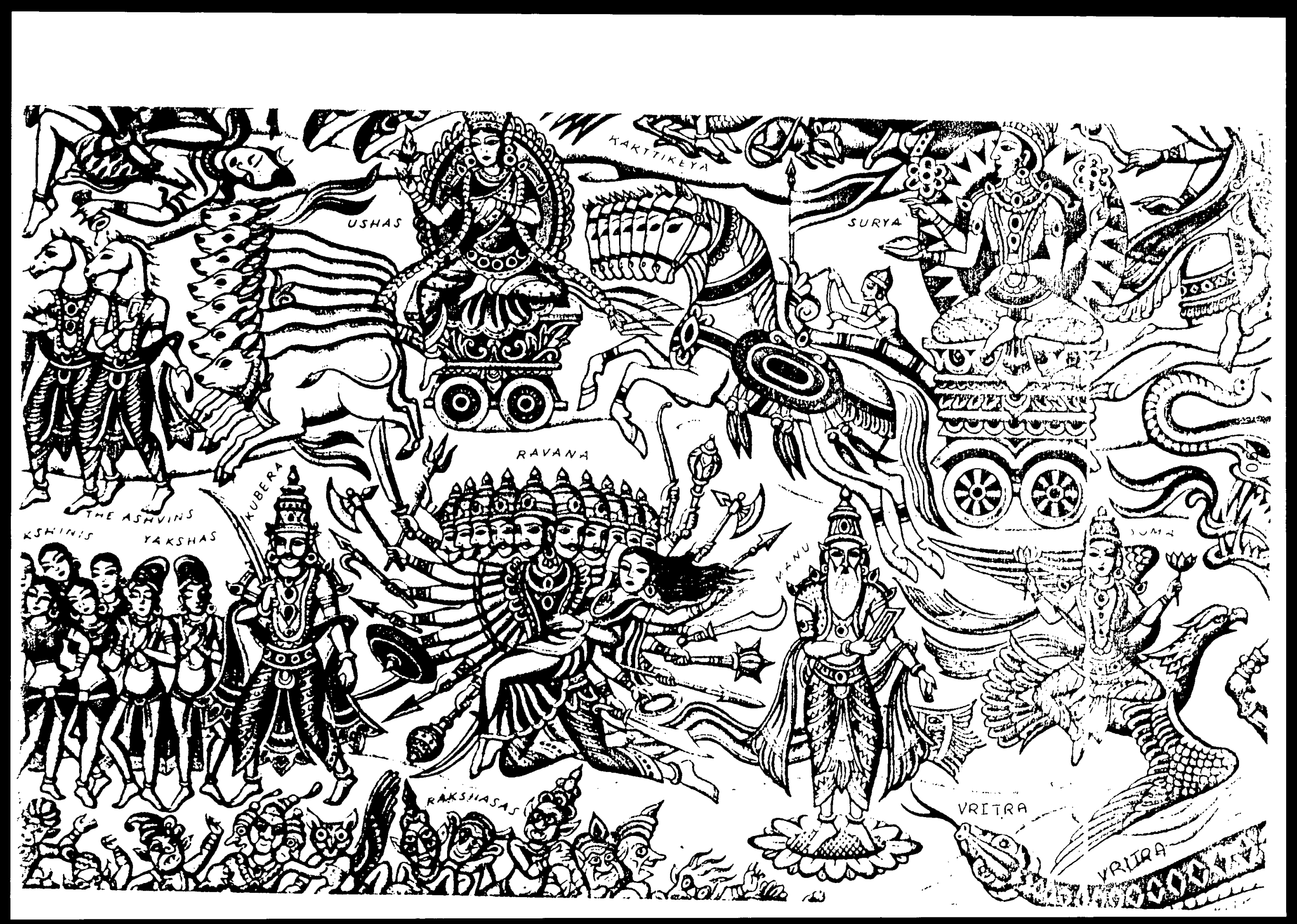


APPENDIX E

SELECTED CHRISTIAN HINDU BHAJANS

WITH ENGLISH TRANSLATIONS 
HINDI BHAJANS AND ENGLISH TRANSLATIONS

compiled by

Justin Sher Singh

New Delhi, India 
BHAJANS

\section{VANDANA DARTE HAIN HUM}

1. Vandana karte haim hum, Vandana karte hain hum. Hirday ko tere samne, Lakar rakhte hain hum.

2. Hirday maim mere Masiha, Jivan jyoti jala, Hirday ke papen ko dhokar, Prema ki raha dikha. (Repeat the first verse)

\section{YESHU KE PICHE MAIN CHALNE} IAGA

1. Yeshu ke piche main chalne laga.

Na lautuaga, na

lautunga.

2. Gar koi mare sath na aawe.

Na lautunga, na

lautunga.

3. Duniya ko chor ke, Salib ko leke. Na lautunga, na lautunga.

\section{PARAMA PITA KI HUM STUTI}

\section{GAYEN}

Parama Pita ki hum stuti gayen,

Woh hi hai jo bachata

hamen.

Sare papon ko karta

chama,

Sare rogon ko karta changa .

\section{ENGLISH TRANSLATION}

We worship you,

We worship you.

This heart of ours,

We present before you.

In this heart of mine, Lord Jesus, Light the light of life Wash the sins from my heart,

Show me the path of love

$$
\text { * } \ldots *
$$

I have decided to follow Jesus.

No turning back, no

turning back.

Though no one join me, yet I will follow.

No turning back, no

turning back.

The world behind me, the cross before me.

No turning back, no turning back.

$$
\text { * * * }
$$

Let us sing praises to the Almighty God.

He is the one who saves us

He forgives all our iniquities.

He heals all our diseases. 
1. Woh hi hamara hai parama Pita, Tarasa khata hai sarva sada.

Purab se pachchim jitna dur, Utne hi dur hamare kasur.

2. Maan ki tarhan usne di taali, Duniya ke khatron mein chora nahin. Hum ko bachane kko jaan apni $d i$, Aur di hamesha ki zindagi.

3. Ghonsale ko bar bar tor kar usne, Chaha $\mathrm{ki}$ seekhen hum urna usse.

Paron par uthaya aukab ki tarhan,

Taaki hum ko chot na lage.

4. Dhanyabad dein uske aasanon mein, Anand se aayen uske charanon mein. Sangeet gaake khushi se,

Mukti chattan ko jai lalkaren.

\section{TUM TO MASIHA MORE ANKHON} KE TARE

Tum to Masiha more askhon ke tare, Bhulo na mori khabariya.

1. Raha baat ham bhule phirat hain, Paap ki bhari gathariya, Ha ha karata, tori binati karata, Masih apni bata do dagariya.
He is our Almighty God.

He is everlastintgly compassionate to us.

As far as the east is from the west

That far He removed our sins from us.

Like a mother He has comforted us.

He does not leave us to the perils of this world He gave us His life to save us

He has also given us eternal life.

Time and again He tears up the nest,

In order to teach us how to fly.

Like the eagle He carries us on His wings,

So that we may not be hurt.

Let's come into his gates with thanksgiving, Let's come to His feet with rejoicing.

Let's come singing songs of gladness,

Let's shout praises to the Rock of our salvation.

Lork Jesus, you are the light of mine eyes. Leave me not forsaken.

We have lost our way and are wandering, The load of sin is too heavy to bear. with loud crying I entreat Thee, Lord Jesus, tell us your abiding place. 
2. Paap ki nadiya gehri bahut hai,

Labha ki uthat

lehariya,

Le chala khewana haare Masiha,

Mori to tuti navariya.

3. Mun ki yeh chaadar maili jo ho gayi, Jaise ki kari badariya. Apne pakata mein dho do Masiha, Mun ki yeh maili chadariya.

4. Yeh Shaitan bara dukh dayi, Chup chup ke mare katariya.

Sabir ke augan chipao Masiha, Tori to piyari nazariya.

\section{JAI JAI YESHU, JAI JAI}

\section{YESHU}

Jai jai Yeshu, jai jai Yeshu.

Jai Prabhu jai jai kar,

Sirajanahar, Palanahar, Taranahar.

1. Dinon ka khuka harne wala, Hirday mein shanti bharane wala. Jai jana ranjan, jai sukh bhanjan, Jai prabhu jai jai kar, Sirajanahar--
The river of $\sin$ is too deep, The waves of greed heave over me.

Redeemer Lord, carry me accross, or else my life boat is about to break.

The sheet of my heart is soiled with sin, Just like the dark clouds. Wash it in your blood, Jesus,

This dirty heart sgeet of mine.

This devil gives me lots of trouble,

He strikes at me unbeknown to me.

Lord Jesus, cover me in your shelter, I long for your compassionate look.

$$
\text { * } * \text { * }
$$

Praise, praise be unto you, Lord Jesus.

Praise and glory unto you Lord,

Creator, sustainar, Redeemer.

You have borne our grief,

You fill our hearts with peace.

Praise redeemer Lord, praise Prince of Peace. Praise and glory to you. 
2. Nirtan dhar liyo autara, De nija prana diyo chutkara.

Jai jag trata, fai sukha data,

Jai Prahu jai jai kar, Sirajanahar--

3. Mirtiyu bandhana bhanjana hara, Akshai jivana dewana hara, Rogina, shogina, eka audhara, Jai Prabhu jai jai kar, Sirajanahar--

4. Jai jai kara karo sub piyaro,

Nara, nari eka sanga pukaro.

Nare maro, jai lalkaro,

Jai Prabhu jai jai kar, Sirajanahar--

INJIL KO PHAILANA

Injil ko phailana, yeh kam hamara hai. Munji ka zamane mein, yeh nam piyara hai.

1. Kandhon pe saliben hon, Injil ho hathon mein, Duniya ko bata denge, Yeshu hi kafara hai.

2. Duniya mein teri shaurat, Azmat hai phirishton mein.

Mariam ka dulara hai, Munji tu hamara hai.
You became a man and took our form,

You gave your life and redeemed us.

Praise Creator Lord, praise Prince of Peace. Praise and glory be unto you.

You broke the cords of death, You offer us life everlasting.

You have taken our curse away from us, Praise and glory be unto you.

Let everyone praise the Lord, Men and women, raise the chorus together,

Shout praises, shout aloud, Praise and glory be unto you.

$$
\text { * } \star *
$$

To spread the Gospel is our mission.

That the name of the Redeemer be endeared on earth.

With the cross on our shoulders, And the Bible in our hands.

We shall declare to the world, That Jesus alone is the Saviour from sin.

Your name is exalted in all the earth, You are revered among the angels.

You are beloved of Mary, You aare our Redeemer. 
3. Hum Khun ka har katra, Hans hans ke baha denge.

Taglif ka kiya kehna,

Marna hi gawara hai.

\section{JAO, JAO, HEY MERE CHELO}

Jao, jao, hey mere chelo,

Karo prem parchar.

1. Gaon, basti, shehr ba shehr,

Jitne hain duniya mein. Jungle, parvat, nadi o nale,

Jaiyo sub ke par, Jao, jao--

2. Khawf na karna, kabni na darna,

Main hun har dam sath.

Prem ke naiya, prem

khivaiya,

Prabhu karega par.

3. Jub tum se muqabil

aawe,

Duniya kar saaardar,

Ruh ki tum talwar

uthana,

Zor se karna war.

\section{YESHU SALIB PAR MUWA}

Yeshu salib par muwa, mere liye, tere liye. Kaisa mahan dukh asha, mere liye, tere liye.
Every drop of our blood, We shall shed with smiles on our faces.

Not only trials and persecution,

We shall prefer even death for your sake.

$$
\star \star \star
$$

Go, go, ye my disciples, Preach the Gospel Message.

Every village, town, city after city,

All of them in this world. Jungle, mountains, rivers and creeks,

Go across them all.

Be not fearful, be not afraid, Because I will be with you always

It's love service, it's the loving Saviour.

The Lord will carry you through.

When you are challenged

By the prince of this world, Arm yourself with the sword of the spirit. And attack with vigour.

$$
\star * *
$$

Jesus died on the cross for you and me.

He bore profound grief for you and me. 
1. Mara gaya tha krus par.

Cheda gaya tha krus par.

Main bhi bacha, tum bhi bacho,

Yeshu Krisht ke lahu se.

2. Nadiya woh kaisi khun $\mathrm{ki}$,

Krisht ke pehlu se beh gayin.

Dhul gaye paap, mit gaye dagh

Yeshu krisht ke lahu se.

3. Dho dalo aaj papon ko,

Dil se mita do daghon do.

Ho jaao saaf, tun mun se aaj.

Yahowa ki sazaaon se.

\section{YESHU BULATA TUMHEN}

Yeshu bulata tumher, Gar run ake jhuko, Paoge shanti anand,

Jivan lilega tumhen

1. Woh juvan jal ka sota hai,

Tumko dukh kyun hota hai.

Mun ki pyas bujhaneko.

Jivan jala pilata tumhen.
He was smitten on the cross.

He was pierced on the cross.

I was saved, you can be saved too

By the blood of Jesus.

Blood flowed like a river

From the side of the Lord.

My sins are washed away, stains removed.

By the blood of Jesus.

Let your sins be washed out today

Let the stain be removed from your heart.

Be ye clean in your heart. and soul

By the sufferings of the Lord.

$$
\star * *
$$

The Lord is calling you, If you submit to Him, You will receive peace and joy,

Life everlasting will be yours.

He is the fountain of living water.

Why are you anxious

To satisfy the thirst of your heart,

He gives you everlasting water. 
2. Woh jivana ki roti hai, Phir kyun atma roti hai,

Mun ki pyas bujhaneko.

Jivan roti khilata tumhen.

3. Dukha sankat mein rehta sath, Bhai ke samaye woh thame hath. Khatron se hamko bachane ko, Wohi marga dikhlata tumhen.

\section{KRISHTA YESHU DAYALU PRABHU}

Krishta Yeshu dayalu Prabhu, Tu hi hai taramahar Ham sab gaate heliluiah,

Tu hi hai taranahar.

1. Janama tune, jagat mein liya, Kanghali ghar mein jivana beeta Dukh aur kashta tune uthae,

Kiya hamara udhar. Yeshu piyare, kiya hamara udhar.

Kaya hamara udhar.

2. Jivana maiya khatre mein jab thi, Andhiyon se dagmagati thi, Agya dekar andhi thamadi, Berda kiya tune par. Yeshu piyare, berda kiya tune par. Berda kiya tune par.
He is the bread of life. Why does your soul languish To satisfy the hunger of your heart, He gives you the bread of life.

When in difficulties, He is with you, When in fear, He holds your hand. To save you from the perils of life,

He shows you the path of life.

$$
\text { * * * }
$$

Merciful Lord Jesus,

You are our Redeemer. We all sing halluiah,

Because you are the Redeemer.

Incarnated into this world, You spent your life in a poor home.

You bore trials and pain, And thereby redeemed me.

When my life boat was in danger, Rocked by waves and billows, You commanded the storm be still.

And carried my life boat to safety. 
3. Murakh Paapi, main jivan bhar ka, Sab kuch bhi karta, kuch na banta, Yeshu, jub tera vastra chua tha, Changa hua yeh bimar, Yeshu.

\section{AA CHUKA HUN DAR PE TERE}

Aa chuka hun dar pe tere, $\mathrm{Ab}$ dua ke waste. Daste basta, chashme giryan

Iltajake waste.

1. Aya khali hath hun main,

Aye Khudawanda karim, Kar karam mujhpar tu shahe

Anbiya ke waste.

2. Dil siyah, aur ruh siyah,

Aur sakhta hi badkar hun.

Hont khul sakte nahin Teri sana ke waste.

3. Pak ruh ab dijiye Aur pak mujhko kijiye. Hai meri yeh iltaja Ibne Khudake waste.
I am a curse sinner for life, All that I do amouts to nothing.

But when I touched the hem of your garment, This sick soul was healed, Lord.

I have come to your door To offer my prayer. Hands clasped, eyes closed To make my pleas before you.

I have come empty handed,

Merciful Lord.

For your majesty sake,

Have mercy on me.

The heart is black, the soul is black.

I am a wicked sinner.

I cannot use my lips

To sing your praises.

Grant me the Holy spirit, And sanctify me. This is my plea, In the name of the eternal God. 


\section{TERE KARAM KE HAIN PYASE}

Tere karam ke hain pyase.

Prem ka sagar hai tu, Khali hai daman hamara.

1. Ham tere paapi bande, Papon mein hai andhe. Itna karam tu kar de, Piyar se daman bhar de.

2. Bhar de yeh sir jhuka hai,

Suna le dua hamari. Tufan mein hai kishti, Naiya par lago de.

\section{JIVANA HAI EKA NAO}

Jivana hai eka nao, Prem ka sagar hai tu. Khali hai daman hamara.

1. Ashaaon ke deepa jalakar,

Gir kar uthakar aur pachtakar,

Bhole musafir, rahape aja, Jaise bhi ho dushwar kiye chal, par liye chal--

2. Wakt hai thora, raha kathin hai, Moorakha man kyun malin hai,

Mat ja kinare, dhar pe aja,

Jaise bhi ho majkhar liye chal par liye chal--

$$
\text { * * * }
$$

We thirst for your mercies.

You are the ocean on love. our lives are empty without you.

We are your sinful followers

Sin has blinded us. Grant just this favour, Fill these lives of ours with your love.

Fill us up, our heads are bowed, Hear our prayers. This life is in the stormy sea,

Carry it to safety.

$$
\text { * * * }
$$

Life is like a canoe. Redeemer Lord, You row me accross.

Light the lamp of hope

Fallen down, repented, and risen up again,

Lost pilgrim, come on course, However difficult, row me accross.

Time is short, the road is difficult.

Foolish heart, why are you confused?

Don't ren ashore, come mid-stream.

However difficult, row through the current. 
Aawaz uthayenge, hum saaz bajayenge, Hai Yeshu mahan apna, yeh geet sunayenge.

1. Sansaar ki sunderta mein

Yeh rup to tera hi, In chand sitaron mein, hai aks bhi tera hi. Mahina ki teri baaten,

Hum eub ko sunayenge, Hai Yeshu mahan hi...

2. Dil tera khazana hai, ek pak muhabbbat ka, Teh pa na saka koi, sagar hai tu ulfat ka. Hum teri muhabbat se, dil apne lagayenge, Hai Yeshu mahan apna...

3. Na dedhsaka jumko, tu paap ke sagar mein, Aur banke manush aaya, aakash se sagar mein. Mukti ka tu kata hai, duniya do bata denge. Hai Yeshu mahan apna...

\section{JAI, JAI YESHU}

Jai prabhu yeshum jai adhi raja, Jai prabhu, jai, jai, ka-ri.

1. Paap nomata dukha laaj uthai, Prana diyo balihari, Jai prabhu Yeshu...

2. Teena dino taba Yeshu ga-ura mein, Teeja divasa nihari, Jai prabhu Yeshu..
We will lift up our voices and play on instruments, We will sing songs to Almighty Jesus.

The beauties of this universe

Bear your likeness. The moon, the stars reflect your glory. We will sing of your omnipotence To all mankind everywhere.

This is the treasure chest of your love.

No one can reach the bottom of your love. We will fill our hearts with your love. Jesus is our Almighty Lord.

You could not bear to see us in the ocean of sin. Becoming a man you plunged from heaven to earth.

We will proclaim to the world

That you are the Savior of man.

Blessed be Lord Jesus, omnipotent King, Blessed Lord, I adore Thee

For my sins you bore pain and shame,

You sanctified your life, so blessed be Lord Jesus.

Three days you remained in the grave, on the third day the grave could not keep you. 
3. Prata samai ravivara dina mein, Strap nivasa chari, Jai prabhu Yeshu...

4. Bhora sawere ghora maranka, Tora bandhan bhari, Jai prabhu Yeshu...

TUN, MUN AUR DHUN

Tun, mun aur dhun use do,

Apne Yeshu ko sub kuch do,

Kyunki usi ke dwara udhar pana hai,

Jiti aatma ka daan use do.

1. Gar Yeshu ke bunna chaho,

Kuch karke dikhana hoga ,

Khud bachna kafi nahi hai

Auron ko bachana hoga. Dil mein paihli jagha use do,

Apne Yeshu ko sub kuch do...

2. Yeshu naam ko apna kehna

Jaise kanton ki raha pe chalna.

Aur suchche masihi

banna,

Sung krus pe uske marna,

Zinda rehne $\mathrm{ki}$ shakti

lelo

Apne Yeshu do sub kuch do...
On Sunday, at dawn,

You broke the bands of death.

Early morning, death was conquered,

You broke the tomb.

$$
* * *
$$

Your body, heart and

treasure, give them to him Give your all to the Lord Jesus.

Because by Him you have been redeemed,

Present your body a living sacrifice.

If you want to belong to Jesus

You will have to prove worthy,

It is not enough if you

save yourself alone.

You'll have to save others as well.

Give Him the first place in your heart.

To be called by Christ's name,

Is lide walking on thorny path.

And to be genuine

Christians

Is to be willing to

crucify yourself.

Obtain life sustaining power from Him

Give your all to the Lord Jesus. 


\section{Chorus}

Yishu ne kaha, Jivan ki roti

Jivan ko roti main hi hun.

1. Yeshu ne kaha, sachcha gadariya,

Sachcyha gadariya main

hi hun. Yishi ne...

2. Yishu ne kaha, Marg aur phatak,

Marg aur phatak main hi hun.

3. Yishu ne kaha, jagat ka ujiyala, Jagat ka ujiyala main hi hun.

4. Yishu ne kaha, Maut se jilawa,

Maut se jilawa main hi hun.
* * *

Jesus said, "I am the bread of life."

Jesus said, "I am the good Shepherd."

Jesus said, "I am the door."

Jesus said, "I am the light of the world."

Jesus said, "I am the resurrection." 
APPENDIX F

TEST FOR TRAINING WORKSHOP 
TEST

Name.......................

Church or district................

Date.........

A. General

on the line at the end of each statement or word on

the left write letter that for the statement or word on the right that it matches.

1. Major Hindu sect in Trinidad

a. Brahman

2. Primary Hindu Scripture

b. Shiva

3. Most popular Hindu Scripture

c. Rhamayana

4. Supreme Being in Hinduism

d. Maha Saba

5. Two epics

e. Vishnu

6. Conflict between two sets of cousins the Pandavas and the Kauravas..... was the hero

7. He is a deity who is the destroyer g. Arjuna

8. He is the creator in Hinduism h. Brahmins

9. Most popular Hindu festival in Trinidad g. Mahabharata 
10. Primary Hindu social

structure

h. Devali

i. Brahma

j. Church

k. Family

B. The Ramayana

1. Fill in the blanks in this paragraph with the appropriate words in brackets ant the end, a word may be used more than once.

.......... was a prince of Ayodhya was exiled to the forest with his wife ....., one day she was captured by ....... most powerful demon king from ........ With the assistance of ...... Rama defeated ........ and rescued ....... Rama, Vishnu, Indra , Ravana, Krishna, Sita, Lanka, Hanuman].

C. Man

1. In harmony with the Hindu concept of the human, underline all the statements below that correctly refer to aspects or parts of the human body.
a. Soma body
b. Physical body.
C. Astral body
d. spiritual body
e. Subtle body
f. Causal
body .

2. According to Hindu teaching about the human, circle the in the list below the correct bodies that continue to live after death. 
a. Subtle and casual body b. physical and subtle body c. Casual and mental body.

D. Salvation

In not more than two sentences define the following;

1. Moksha.............................

2. Sansara

3. Karma

E. Castes

The list of the caste on the left, number them in order using " 1 " for the most elevated and "5" for the lowest. In addition draw a line from the caste on the left to the matching role on the right.
1. -- Untouchable
(a) merchants
2. -- Vaishyas
(b) priests and scholars
3. -- Shudras
(c) Warriors
4. -- Kshatriyas
(d) pollutants
5. -- Brahmins
(e) serfs who serve and
(f) support the others

F. General

Complete the following statements by filling in the blanks.

1. The ..... or ........... is the most influential person in the average Hindu family. 
$2 . \ldots \ldots \ldots \ldots$ and $\ldots \ldots \ldots$ are issues of common concern to both Hindus and Seventh-day Adventists.

G. Salvation in Hinduism is by............ (underline the correct answer, (a) faith; (b) works; (c) faith and works; (d) none of the above. 
BIBLIOGRAPHY 


\section{BIBLIOGRAPHY}

Books

Annual Statistical Digest 1988. No. 32. 23 Park Street, Port-of-Spain, Trinidad: Ministry of Finance and Planning, Central

statistical office, 1987.

Annual Statistical Report. Washington, D. C.: General Conference of Seventh-day Adventist, office of Archives and statistics, 1987.

Armstrong, Richard Stoll. The Pastor as Evangelist. Philadelphia: Westminster Press, 1984.

Barclay, William. Acts of the Apostles. Philadelphia: Westminster Press, 1976.

Basham, A. L. The Wonder That Was India. New York: Grove Press, 1959.

Black, Jan Knippers; Blutstern, Howard I.; Johnston, Kathryn Therese; and Mc Morris, David S. Area Hand Book for Trinidad and Tobago. Washington, D.C.: Government Printing Office, 1976.

Bowker, John. The Problem of Suffering in Religions of the World. Cambridge: The University Press, 1970 .

Brown, Colin. The New International Dictionary of New Testament Theology. 4 vols. Grand Rapids, Michigan: Zondervan Publishing House, 1986.

Buttrick, George Arthur. ed. The Interpreter's Bible. 12 vols. New York: Abingdon Press, 1954.

Chandy, Verghese. "Obstructions and strategizing in Church Planting among Tamil Hindus in Sri Lanka." D.Miss. dissertation, Fuller Theological Seminary, 1984. 
Coe, Shoki. "Contextualizing Theology." In Mission Trends No 3., Edited by Gerald H. Anderson and Thomas F. Stransky. Grand Rapids, Michigan: William B. Eerdmans Publishing Co. and Paulis Fathers, 1976.

"The Consultation on World Evangelization MiniConsultation on Reaching Hindus."In The Thailand Report on Hindus. Wheaton, Illinois: Lausanne Committee for World Evangelization, 1980.

Dayton, Edward R., and Fraser, David A. Planning Strategies for World Evangelization. Grand Rapids, Michigan: William B. Eerdmans Publishing Company, 1980 .

Dhavamony, M. "Dialogue with Hinduism." In Evangelization, Dialogue and Development. Edited by M. Dhavamony. Rome: Universita Gregoriana Editrice, 1972.

Duvois, J. A. Hindu Manners, Customs and Ceremonies. Oxford: Clarendon Press, 1906.

East Indian Cultural Promotions. Swaagtam (an Annual Divali Publication). N.P.: By the Author, October 1987.

Elder, Joseph W. "Hinduism." Collier's Encyclopedia, 1987. $12: 127-133$.

Erdman, Charles R. The Acts. Grand Rapids, Michigan: Baker Book House, 1983.

Goetzman, J. "Oil1Ses_," The New International Dictionary of New Testament Theology. 4 vols. Edited by Colin Brown. Grand Rapids, Michigan: Zondervan Publishing House, 1986.

Gosvami, Satavarupa dasa. Reading in Vedic Literature. Los Angeles, California: Bhaklivedanta Book Trust, 1977.

Gromak, Robert G. Called to Be Saints. Grand Rapids, Michigan: Baker Book House, 1977.

Gutzke, Manford George. Plain Talk on Acts. Grand Rapids, Michigan: Zondervan Publishing House, 1966.

Harrison, Everett F. Interpreting Acts: The Expanding Church. Grand Rapids, Michigan: Zondervan Publishing House, 1986. 
Hastings, Edward. The Speaker's Bible. The Gospel According to st. Matthew. Grand Rapids, Michigan: Baker Book House, 1971.

Henry, Carl F. The Biblical Expositor. Vol.2. Philadelphia: A. J. Holman Company, 1960.

Hitlal, Aaron. "The Origin and Early Development of the Seventh-day Adventist Movement in Trinidad and Tobago." M. Div. thesis, Andrews University, 1973.

Howard, J. K. New Testament Baptism. London: Pickering and Inglis, 1970.

Institute for New Testament Research and Computer center of Muster University, ed. Concordance of the Novum Testamentum Grace. 3rd ed. Berlin: Walter De Gruyter, 1987.

Johnson, Ben Campbell. Rethinking Evangelism: A Theological Approach. Philadelphia: Westminster Press, 1987.

Kinsley, David R. Hinduism. Englewood Cliffs, New Jersey: Prentice Hall, 1982.

Kittel, Gerhard. Theological Dictionary of the New Testament. 10 vols. Grand Rapids, Michigan: William B. Eerdmans Publishing Company, 1967.

Kung, Hans. "The World Religions in God's Plan of Salvation." In Christian Revelation and World Religion. Edited by Joseph Neuner. London: Burns and Oates, 1967.

Lenski, R. C. H. The Interpretation of st. Paul's First and Second Epistle to the Corinthians. 12 vols. Columbus, Ohio: Walburg Press, 1964.

Luce, Henry R., ed. The World's Great Religions. New York: Time, 1957.

Maharaj, Satnaraya. "Hindu Schools--Their Origin." In Indian Arrival Day 30th May 1985 - Maha Sabha Day 2nd June 1985. Edited by Hardeo Singh and Motilal Gocool. Siparia, Trinidad: Soodhai's Printery, 1985. 15,16 . 
Malik, Yogendra K. East Indians in Trinidad: A Study in Minority Politics. London \& New York: Oxford University Press. 1971.

McGavran, Donald. The Bridges of God. New York: Friendship Press, 1968.

- The Clash Between Christianity and Cultures. Washington, D.C.: Cannon Press, 1974 .

- Momentous Decisions in Missions Today. Grand Rapids, Michigan: Baker Book House, 1984.

Morgan, Kenneth W., ed. The Religion of the Hindus. New York: Ronald Press Company, 1953.

Muller, D. "llQ $\theta_{\text {H }}$ ís." The New International Dictionary of the New Testament. 4 vols. Edited by Colin Brown. Grand Rapids, Michigan: Zondervan Publishing House, 1986.

Murray, Eric John. A History of the Seventh-day Adventist Church in Trinidad and Tobago 1891-1981. Trinidad: The College Press, 1982.

Neuner, Joseph., ed. Christian Revelation and World Religions. London: Burns and Oates, 1967.

Niehoff, Arthur, and Niehoff, Juanita. East Indians in the West Indies. Milwaukee, Wisconsin: Milwaukee Public Museum, 1960.

Niles. D. T. That They May Have Life. New York: Harper and Row Publishers, 1951.

Nyrop, Richard F.; Benderly, Beryl Lieff; Cover, William W.; Cutter, Melissa J.; Parker, Newton. Area Handbook for India. Washington, D.C.: Foreign Area Studies, The American University, 1975.

O'Malley, L. S. S. Popular Hinduism. New York: Johnson Reprint Corporation, 1970.

Padilla, Rene. "The Contextualization of the Gospel." In Readings in Dynamic Indigeneity. Edited by Charles H. Kraft and Tom N. Wisley. Pasadena, California: William Carey Library, 1979.

Panikkar, Raymond. "The Unknown Christ of Hinduism." In Christianity and other Religions. Edited by John Hicks and Brian Hebblethwaite. Glasgow: William Collins Sons and Company, 1980. 
Parasram, Rampersad. "Alcoholism: Results of A Survey." In Indian Arrival Day 30th May 1985 - Maha Sabha Day 2nd June 1985. Edited by Hardeo Singh and Motilal Gocool. Sipaaria, Trinidad: Sookhai's Printery, 1985. 29.

- "Report of an Investigation into Parasuicide." In Indian Arrival Day 30th May 1985 - Maha Sabha Day 2nd June 1985. 33 .

Patterson, Paige. The Troubled Triumphant Church. Nashville: Thomas Nelson Publishers, 1983.

Pentecost, Edward C. Issues in Missiology. Grand Rapids, Michigan: Baker Book House, 1982 .

Ponniah, Melchizedek Mithraraj. "The Concept of Contextualization and Its Implications for the Seventh-day Adventist Theological Education in India," Ph. D dissertation, Andrews University, 1986.

Prior, Kenneth F. W. The Gospel in a Pagan Society. Downer's Grove, Illinois: InterVarsity Press. 1975.

Ramlakhan, Kamla. "Need for Cultural Awareness." In Indian Arrival Day 30th May 1985 - Maha Sabha Day 2nd June 1985. Edited by Hardeo Singh and Motilal Gocool. Siparia, Trinidad: Sookhai's Printery, 1985. 39,40 .

Rengstorf, R. H. "fla the New Testament. 10 vols. Edited by Gerhard Kittel. Grand Rapids, Michigan: William B. Eerdmans Publishing Company, 1968.

Ross, Aileen D. The Hindu Family in Its Urban setting. Toronto: University of Toronto Press, 1961.

Samaroo, Brinsley. "The Early Years of East Indian Immigration." In Indian Arrival Day 30th May1985 - Maha Sabha Day 2nd June 1985. Edited by Hardeo Singh and Mitilal Gocool. Siparia, Trinidad: Sookhai's Printery, 1985. 21-23.

Schebera, Richard L. Christian/Non-Christian Dialogue. Washington, D.C.: University Press of America, 1978 . 
Seventh-day Adventist Bible Commentary. 7 vols. Edited by F. D. Nichol. Washington, D. C.: Review and Herald Pub. Assn., 1957. 5:557.

Seventh-day Adventist Yearbook. Hagerston, Maryland: Review and Herald Pub. Assn., 1987.

Simpson, George Eaton. Religious Cults of the Caribbean: Trinidad, Jamaica, and Haiti. Rio Piedras, P. R.: Institute of Caribbean Studies, University of Puerto Rico, 1970.

Singh, Hardeo, and Gocool, Motilal, eds. Indian Arrival Day 30th May 1985 Maha Sabha Day 2nd June 1985. Siparia, Trinidad: Sookhai Printery, 1985.

Sthalekar, Haren. "Development, Implementation, and Evaluation of an Evangelistic Approach for Gujarati Hindu Indians in Kenya," D. Min. project report, Andrews University, 1984 .

Stowe, David M. When Faith Meets Faith. New York: Friendship Press, 1967.

Subbamma, B. V. New Patterns for Descipling Hindus. South Pasadena, California: William Carey Library, 1970 .

Swearer, Donald K. Dialogue: The Key to Understanding Other Religions. Philadelphia: Westminster Press, 1977 .

Taber, Charles R. "Contextualization: Indigenization and/or Transformation, In The Gospel and Islam Edited by Don M. McCurry. Monrovia, California: Mission Advanced Research and Communication Center, 1979

- "The Limits of Indigenization in Theology," In Readings in Dynamic Indigeneity. Edited by Charles H. Kraft and Tom N. Wisley. Pasadena, California: William Carey Library, 1979.

Vidyarthi, D. N. What Every Hindu Must Know. St. Augustine, Trinidad: Texprint, 1988 .

Vine, W. E. An Espository Dictionary of New Testament Words. Nashville: Thomas Nelson Publishers, 1985. 


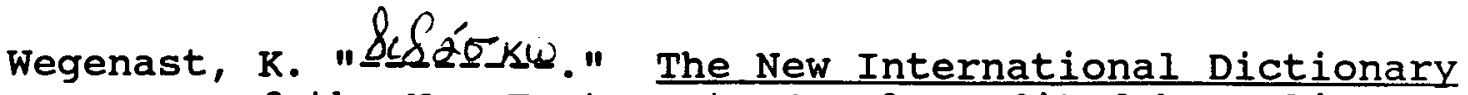
of the New Testament. 4 vols. Edited by Colin Brown. Grand Rapids, Michigan: Zindervan Publishing House, 1986.

White, Ellen G. The Acts of the Apostles. Mountain View, California: Pacific Press Publishing Association, 1911.

- The Desire of Ages. Mountain View, California: Pacific Press Publishing Association, 1940.

- The Ministry of Healing. Mountain View, California: Pacific Press Publishing Association, 1942 .

- Patriarchs and Prophets. Mountain Veiew, California: Pacific Press Publishing Association, 1913.

- Testimonies for the Church. 9 vols. Mountain View, California: Pacific Press Publishing Association, 1948

- Welfare Ministry. Washington, D.C.: Review and Herald Publishing Association, 1952.

Willmott, John. "Urban Evangelism in India: An Evangelistic Project Conducted in the city of Poona." D.Min. project report. Andrews University, 1981.

Younger, Paul, and Younger, Susanna olmmen. Hinduism. Niles, Illinois: Argus Communications, 1978.

\section{Periodicals}

Buswell, James 0 . III. "Contextualization: Is It only a New Word for Indigenization?" Evangelical Mission Quarterly 14, no. 1 (1978): 13-20.

Charles, Vijayan. "India." Adventist Review, July 9, 1987, 8-10.

Gilman, John." Karunamayudu." Christian Life 46 (19841985): 70-74. 
Haleblian, Krikor. "The Problem of Contextualization." Missiology: An International Review 11, no. 1 (1983): 95-111.

Jha, J. C. "The Hindu Sacraments (Rites de Passage) in Trinidad and Tobago." Caribbean

Quarterly 22, no. 1 (1976): 40-52.

" Indian Heritage in Trinidad (West Indies)."

Eastern Anthropologist 27, no. 3 (July-September 1974): 211-234.

Kraft, Charles H. "The Contextualization of Theology." Evangelical Mission Quarterly 14 (1978): 31-36.

Kinsler, F. Ross. "Mission and Context: The Current Debate about Contextualization." Evangelical Mission Quarterly 14, no. 2 (1978): 23-29.

Legrand, L. "The Unknown God of Athens." Vidyajyote 45 (May 1981): 222-231.

Matthey, Jacques. "The Great Commission of Matthew." International Review of Missions 69, no. 274 (1980): 161-173.

Niehoff, Arthur. "The Survival of Hindu Institutions in an Alien Environment." Caribbean studies 5, no. 36 (April 1965): 171-187.

O'Brien, P. T. "The Great Commission of Matthew 28: 1820." The Reformed Theological Review 35 , no. 3 $(1976): 66-78$.

Peters, Ted. "A Christian Theology of Interreligious Dialogue." Christian Century 103, no. 30 (July-December 1986): 883-885.

Rogers, Cleon. "The Great Commission." Bibliotheca Sacra 130, no. 519 (July/September 1973): 260-267.

Runyon, Ronald D. "Principles and Methods of Household Evangelism." Bibliotheca Sacra 142 (JanuaryMarch 1985): 64-73.

Schwartz, Barton M. "Patterns of East Indian Family Organization in Trinidad." Caribbean Quarterly 5, no. 1 (April 1965): 23-36.

. "Ritual Aspects of Caste in Trinidad." Anthropological Quarterly 37 , no. 1 (January 1964): 1-15. 
Swidler, Leonard. "Interreligious Dialogue: A Christian Necesity." Cross Currents 35, no. 2/3 (Fall 1985): 129-147.

Taylor, Richard W. "Christian Ashrams as a style of Mission in India." International Review of Missions 68, no. 271 (July 1979): 281-291. 
VITA

Name: Wynall Fitzgerald Kerr

Date and Place of Birth:

February 9, 1949

Scarborough, Tobago,

Republic of Trinidad and Tobago

Undergraduate and Graduate Schools Attended:

West Indies College, Mandeville, Jamaica Kettering Medical Center, Kettering, ohio Andrews University, Berrien Springs, Michigan

Degrees Awarded:

$\begin{array}{ll}1975 & \text { Bachelor of Theology } \\ 1987 & \text { Master of Divinity } \\ 1990 & \text { Doctor of Ministry }\end{array}$

Positions Held:

1968-72 Public Servant, Government of the Republic of Trinidad and Tobago

1975-77 Chaplain and Bible Teacher, Harmon High School of Seventh-day Adventists, Scarborough, Tobago

1977-84 District Pastor, South Caribbean Conference of Seventh-days Adventist, Trinidad 